\title{
Improvements for the Western North Atlantic, Caribbean and Gulf of Mexico ADCIRC Tidal Database (EC2015)
}

\author{
Christine Szpilka ${ }^{1, *}$, Kendra Dresback ${ }^{1}$, Randall Kolar ${ }^{1}$, Jesse Feyen ${ }^{2}$ and Jindong Wang ${ }^{3,4}$ \\ 1 School of Civil Engineering and Environmental Science, University of Oklahoma, 202 W. Boyd Room 334, \\ Norman, OK 73019, USA; dresback@ou.edu (K.D.); kolar@ou.edu (R.K.) \\ 2 NOAA/Great Lakes Environmental Research Laboratory, 4840 South State Road, Ann Arbor, MI 48108, USA; \\ Jesse.Feyen@noaa.gov \\ 3 NOAA/National Ocean Service/Coast Survey Development Laboratory, 1315 East-West Highway, \\ Silver Spring, MD 20910, USA; jindong.wang@gmail.com \\ 4 Earth Resources Technology, Inc., 14401 Sweitzer Lane, Suite 300, Laurel, MD 20707, USA \\ * Correspondence: cmszpilka@ou.edu; Tel.: +1-405-325-5911
}

Academic Editor: Richard P. Signell

Received: 17 July 2016; Accepted: 1 November 2016; Published: 8 November 2016

\begin{abstract}
This research details the development and validation of an updated constituent tidal database for the Western North Atlantic, Caribbean and Gulf of Mexico (WNAT) region, referred to as the EC2015 database. Regional databases, such as EC2015, provide much higher resolution than global databases allowing users to more accurately define the tidal forcing on smaller sub-region domains. The database last underwent major updates in 2001 and was developed using the two-dimensional, depth-integrated form of the coastal hydrodynamic model, ADvanced CIRCulation (ADCIRC), which solves the shallow-water equations in the generalized wave continuity equation form. Six main areas of improvement are examined: (1) placement of the open ocean boundary; (2) higher coastal resolution using Vertical Datum (VDatum) models; (3) updated bathymetry from global databases; (4) updated boundary forcing compared using two global tidal databases; (5) updated bottom friction formulations; and (6) improved model physics by incorporating the advective terms in ADCIRC. The skill of the improved database is compared to that of its predecessor and is calculated using harmonic data from the National Oceanic and Atmospheric Administration Center for Operational Oceanographic Products and Services (NOAA CO-OPS) stations and historic International Hydrographic Organization (IHO) data. Overall, the EC2015 database significantly reduces errors realized in the EC2001 database and improves the quality of coastal tidal constituents available for smaller sub-regional models in the Western North Atlantic, Caribbean and Gulf of Mexico (WNAT) region.
\end{abstract}

Keywords: tidal constituent database; WNAT region; ADCIRC

\section{Introduction}

Small-scale regional hydrodynamic models are widely used to study many varied physical processes such as sediment transport [1-3]; storm surge inundation [4-6]; real-time surge forecast systems [7-10]; sea level rise [11-14]; passive fish and larval transport, as well as coupled ecological behavior [15-17]; combined hydrologic and hydrodynamic processes [9,18]; passive transport of oil spills [19] and coupled hydrodynamic-marsh interactions with biological feedback [20]. Each of these complex applications requires reliable tidal boundary forcing in order to provide accurate results. In particular, many coastal ocean models utilize tidal databases in order to specify the tidal boundary conditions in these regional studies. When no other data is available, the boundary conditions are 
often selected from global tidal databases. However, while global tidal databases are highly accurate in the deep ocean, they often lack the resolution over continental shelves and in the shallower near-shore regions to adequately resolve the astronomical and associated nonlinear tides in the immediate coastal regions [21]. Therefore, it is necessary to create smaller-scale tidal databases that are able to resolve the near-shore environment. Over the past 25 years, three such databases have been developed for the eastern coast of the United States [22-24]. These regional databases use the finite element ADvanced CIRCulation model (ADCIRC) forced with a global tidal database at the open ocean boundary to develop the tidal profile within the domain.

Historically, the eastern (and gulf) coast of the United States has been modeled with a large domain that encompasses the entire Western North Atlantic, Gulf of Mexico and Caribbean Sea, herein referred to as the WNAT domain, and has traditionally had the open ocean boundary located at the $60^{\circ} \mathrm{W}$ meridian $[22,25,26]$. This larger domain provides easier forcing as the boundary lies mostly in the deeper Atlantic Ocean and includes only a small portion of the continental shelves near the coastline.

The first tidal database for the WNAT region, EC1991, was state of the art for its time and had 19,858 nodes and 36,653 elements with elements ranging from $7 \mathrm{~km}$ at the coastline to about $140 \mathrm{~km}$ in the deeper ocean. The bathymetry was extracted from the Earth Topography 5 min gridded resolution (ETOPO5) global bathymetric database. The EC1991 database included elevation and velocity harmonics for the $\mathrm{O}_{1}, \mathrm{~K}_{1}, \mathrm{Q}_{1}, \mathrm{M}_{2}, \mathrm{~S}_{2}, \mathrm{~N}_{2}$ and $\mathrm{K}_{2}$ constituents [22].

An updated version, EC1995, was created in order to take advantage of the National Ocean Service (NOS) hydrographic survey database for nearshore bathymetry, which has since been digitized [27]. The NOS bathymetric database includes raw sounding tracks from ship surveys and typically covers coastal areas out to the continental shelf in U.S. coastal waters. This updated version had 31,435 nodes and 58,369 elements and a minimum element size of $750 \mathrm{~m}$ in Perdido Bay between Alabama and Florida and a maximum element size of $105 \mathrm{~km}$. The average coastal element size was about $5 \mathrm{~km}$ with regions of the Florida peninsula and the Gulf Coast west of the Mississippi River typically having $10 \mathrm{~km}$ resolution. The EC1995 database included elevation and velocity harmonics for the steady, $\mathrm{O}_{1}, \mathrm{~K}_{1}, \mathrm{M}_{2}, \mathrm{~S}_{2}, \mathrm{~N}_{2}, \mathrm{M}_{4}$ and $\mathrm{M}_{6}$ constituents.

The next generation, EC2001, database utilized a grid with 254,565 nodes and 492,179 elements and had a minimum element size of $200 \mathrm{~m}$ in the Mississippi River Delta region and a maximum element size of $29 \mathrm{~km}$. The New Orleans area was the most highly resolved with average element sizes of $1 \mathrm{~km}$ and some areas of finer $500 \mathrm{~m}$ resolution. However, the remainder of the domain had typical coastal element sizes closer to 2-3 km. The original EC2001 database included elevation and velocity harmonics for the $\mathrm{O}_{1}, \mathrm{~K}_{1}, \mathrm{Q}_{1}, \mathrm{M}_{2}, \mathrm{~S}_{2}, \mathrm{~N}_{2}$ and $\mathrm{K}_{2}$ constituents [23]. As an intermediate update, a longer run of 410 days with additional $P_{1}$ tidal boundary forcing was recomputed in 2008, ec2001_v2e [24], to provide the NOS suite of 37 tidal constituents [28] for both species.

In comparison, the latest version, EC2015, database has 2,066,216 nodes and 3,770,720 elements with a minimum element size of $13 \mathrm{~m}$ in the Puerto Rico and Long Island Sound regions (as well as some small Florida channels) and a maximum element size of $46 \mathrm{~km}$ near the open boundary. With a few exceptions, the entire WNAT coastline (United States water only) has typical resolutions of 250-500 m with even more detail in inland channels and inlets. As per the 2008 update to the EC2001 database, the EC2015 database provides the computed amplitude and phase of elevation and velocity for the 37 standard NOS tidal constituents. Table 1 summarizes the grid features of the WNAT domain tidal databases. 
Table 1. Summary of grid features for Western North Atlantic, Caribbean and Gulf of Mexico (WNAT) domain ADvanced CIRCulation model (ADCIRC) tidal databases.

\begin{tabular}{cccccc}
\hline $\begin{array}{c}\text { Database } \\
\text { Name }\end{array}$ & $\begin{array}{c}\text { \# of Mesh } \\
\text { Nodes }\end{array}$ & $\begin{array}{c}\text { \# of Mesh } \\
\text { Elements }\end{array}$ & $\begin{array}{c}\text { Avg. Coastal } \\
\text { Resolution } \mathbf{( k m )}\end{array}$ & $\begin{array}{c}\text { Min. Coastal } \\
\text { Resolution } \mathbf{( m )}\end{array}$ & $\begin{array}{c}\text { Max. Deep Ocean } \\
\text { Resolution } \mathbf{( k m )}\end{array}$ \\
\hline EC1991 & 19,858 & 36,653 & 7 & 1000 & 140 \\
EC1995 & 31,435 & 58,369 & 5 & 750 & 105 \\
EC2001 & 254,565 & 492,179 & 1 to 3 & 200 & 29 \\
EC2015 & $2,066,216$ & $3,770,720$ & 0.25 to 0.5 & 13 & 46 \\
\hline
\end{tabular}

In the next sections, we present the improvements that have been incorporated into this latest generation tidal database and the remaining challenges. We summarize the development of the EC2015 tidal constituent database; present a skill assessment for global, regional and site specific locations; and discuss how the database can and should be used. Limitations of the database are also discussed. In the interest of brevity, we will only present the skill assessment for these 8 primary constituents: $\mathrm{M}_{2}, \mathrm{~S}_{2}, \mathrm{~N}_{2}, \mathrm{~K}_{2}, \mathrm{O}_{1}, \mathrm{~K}_{1}, \mathrm{P}_{1}$ and $\mathrm{Q}_{1}$.

\section{Materials and Methods}

\subsection{ADCIRC Computational Model}

\subsubsection{General Model Details}

As mentioned before, the enhancements to this database will employ the ADCIRC regional hydrodynamic model. ADCIRC utilizes the full non-linear St. Venant (shallow water) equations, using the traditional hydrostatic pressure and Boussinesq approximations. The depth-averaged generalized wave continuity equation is used to solve for the free surface elevation, along with the non-conservative form of the momentum equation for the velocity components. The equations are discretized horizontally in space using continuous Galerkin, linear finite elements with equal-order interpolating functions (linear $\mathrm{C}^{0}$ ), while time is discretized using an efficient, split-step, Crank-Nicholson algorithm with the nonlinear terms evaluated explicitly. There have been many papers written about the development and usage of the ADCIRC computational model, but basic details for the equations of ADCIRC can be found in [29-31].

One of the advances within ADCIRC since the East Coast database was last updated in 2001 is the addition of Manning's $n$ friction representations. Users are able to specify specific quadratic friction coefficients, Chezy friction coefficients or Manning's $n$ values throughout the domain [32]. For the Manning's $n$ implementation, the $n$ values are converted to an equivalent quadratic friction coefficient within ADCIRC before the bottom stress is calculated [30]. This equivalent quadratic friction coefficient is calculated for each node at every time step as

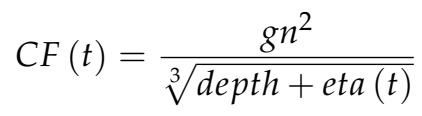

where $g$ is the gravitational constant $\left(9.81 \mathrm{~m} / \mathrm{s}^{2}\right), n$ is the Manning's coefficient, depth is bathymetric depth $(\mathrm{m})$ and $e t a(t)$ is the water surface elevation at time $t(\mathrm{~m})$. Note that the computed quadratic friction coefficient, $C F(t)$, can also be limited on the lower end by specifying the minimum $C F$ value in the input file. Otherwise, the values can become quite small as the depth becomes large.

\subsubsection{Model Input Parameters}

Unless otherwise noted in the appropriate methods and results subsections, all of the ADCIRC model runs used the parameters in the following descriptions. The EC2015 tidal database was developed from a 410-day simulation run in order to capture the long-period non-linear tides. A smooth 
hyperbolic tangent ramp function is applied to both the boundary forcing and the tidal potential forcing functions for the first 25 days. Then the model is allowed to run for another 20 days before the internal ADCIRC harmonic analysis is started for the final 365 days of the simulation. A one-minute interval is used for the internal harmonic decomposition. Tidal potential forcing is applied to the interior of the domain for the $\mathrm{O}_{1}, \mathrm{~K}_{1}, \mathrm{Q}_{1}$ and $\mathrm{P}_{1}$ diurnal constituents and the $\mathrm{M}_{2}, \mathrm{~N}_{2}, \mathrm{~S}_{2}$ and $\mathrm{K}_{2}$ semidiurnal constituents. In addition to these eight constituents, the open ocean boundary is also forced with the $\mathrm{Mm}, \mathrm{Mf}, \mathrm{M}_{4}, \mathrm{MN}_{4}$ and $\mathrm{MS}_{4}$ constituents. Nodal factors and equilibrium arguments were set for a 410-day run starting on November 17, 1991; this translates to the harmonic analysis occurring over the entire year of 1992, which is the middle of the current National Tidal Datum Epoch from 1983 to 2001. Unless otherwise noted, tidal forcing was extracted from the TPXO7.2 global tidal database [33].

A time-step of $1.0 \mathrm{~s}$ was used yielding a maximum Courant number of 0.76 in the U.S. Virgin Islands and of 0.3 along the Atlantic and Gulf coasts. The time weighting factors for the three-level implicit scheme in the GWCE form of the momentum equation are $0.35,0.30$ and 0.35 for the future, present and past time levels respectively. A two-level Crank-Nicholson scheme is used for the momentum equations. The lateral eddy viscosity coefficient was set equal to $5.0 \mathrm{~m}^{2} / \mathrm{s}$ and a non-linear quadratic bottom friction scheme with a constant value of 0.0025 was used for all runs except for the variable bottom-friction comparisons. Specific friction settings for the Manning's $n$ formulation and the variable $C F$ runs are detailed in Section 2.2.5 below; for all variable friction tests, a lower limit of 0.0025 was used. A spatially variable but temporally constant GWCE, $G$ or $\tau_{0}$, parameter was used such that $G$ is dependent upon the local depth and is set as follows: if the depth is $\geq 10, G$ is set to 0.005 , if the depth is $<10, G$ is set to 0.020 .

Due to the large overall mesh domain, variable Coriolis forces were enabled. The non-linear finite amplitude option was utilized with wetting and drying enabled. With the newly expanded open ocean boundary, it was possible to enable the advective terms, as detailed in Section 2.2.6 below.

\subsection{Improvements for the ADCIRC Tidal Database}

The WNAT domain has been improved upon bit by bit over the past 25 years. As technology has progressed in that time, larger computational domains have been possible. Additionally, with advances in remote data collection methods, more accurate and plentiful data is now available for the bathymetric profile of the world's oceans and the location of coastlines. For the latest generation East Coast tidal database, six areas of improvement were examined:

1. Move the open ocean boundary out away from the Lesser Antilles

2. Improve the coastal resolution using the NOAA VDATUM product grids

3. Update the deep water bathymetry

4. Use the latest global tidal database products for forcing on the open ocean boundary

5. Compare three bottom friction schemes for improved accuracy

6. Improve the model physics by enabling the advective terms within ADCIRC

In the following subsections, we detail the methods used for each of these areas. Improvements realized in the harmonic constituent accuracy, as compared with CO-OPS and IHO field measurements, will be presented in the results section.

\subsubsection{Open Ocean Boundary Placement}

The open ocean boundary has been moved out from the traditional $60^{\circ} \mathrm{W}$ meridian that has been used for the past 25 years. Figure 1 shows the new extended model domain with the traditional boundary shown in red as a vertical line near the new boundary. The purpose of this expanded domain was to improve model stability by moving the open ocean boundary further away from the complexities of the Lesser Antilles island chain that separates the Caribbean Sea from the Atlantic Ocean. The traditional EC2001 domain becomes unstable near these islands when the quarter-diurnal 
constituents $\left(\mathrm{M}_{4}, \mathrm{MS}_{4}\right.$, and $\left.\mathrm{MN}_{4}\right)$ are included in the boundary forcing. The EC2001_extended mesh was created at NOAA and has the same coastline and bathymetry in the interior as the EC2001 domain, but with a different boundary location.

There were two guiding principles for choosing this new open ocean boundary location: (1) to avoid any nearby amphidromic regions of the principal tidal constituents- $\mathrm{M}_{2}, \mathrm{~S}_{2}, \mathrm{~N}_{2}, \mathrm{~K}_{1}$ and $\mathrm{O}_{1}$; and (2) to create a smooth boundary with gradually changing element size. For elements closer to the coast, the element size was chosen to be smaller and then to gradually increase in size away from the coast. The new boundary curves to the west near Nova Scotia in order to create a smooth transition, without sharp corners, from the ocean boundary to the land boundary. It also prevents the introduction of the Gulf of St. Lawrence into the model domain. One other important design feature was to avoid having too small of elements across shelf breaks, particularly in the southern part of the boundary near the Lesser Antilles.

After a suitable boundary location was found, a one-year fully non-linear tidal simulation was performed to confirm the stability and robustness of the new boundary location. All thirteen of the TPXO7.2 global tidal model constituents were used to force the open boundary $\left(\mathrm{M}_{2}, \mathrm{~S}_{2}, \mathrm{~N}_{2}, \mathrm{~K}_{2}, \mathrm{~K}_{1}, \mathrm{O}_{1}\right.$, $\mathrm{P}_{1}, \mathrm{Q}_{1}, \mathrm{Mf}, \mathrm{Mm}, \mathrm{M}_{4}, \mathrm{MS}_{4}$, and $\mathrm{MN}_{4}$ ) during this stability test.

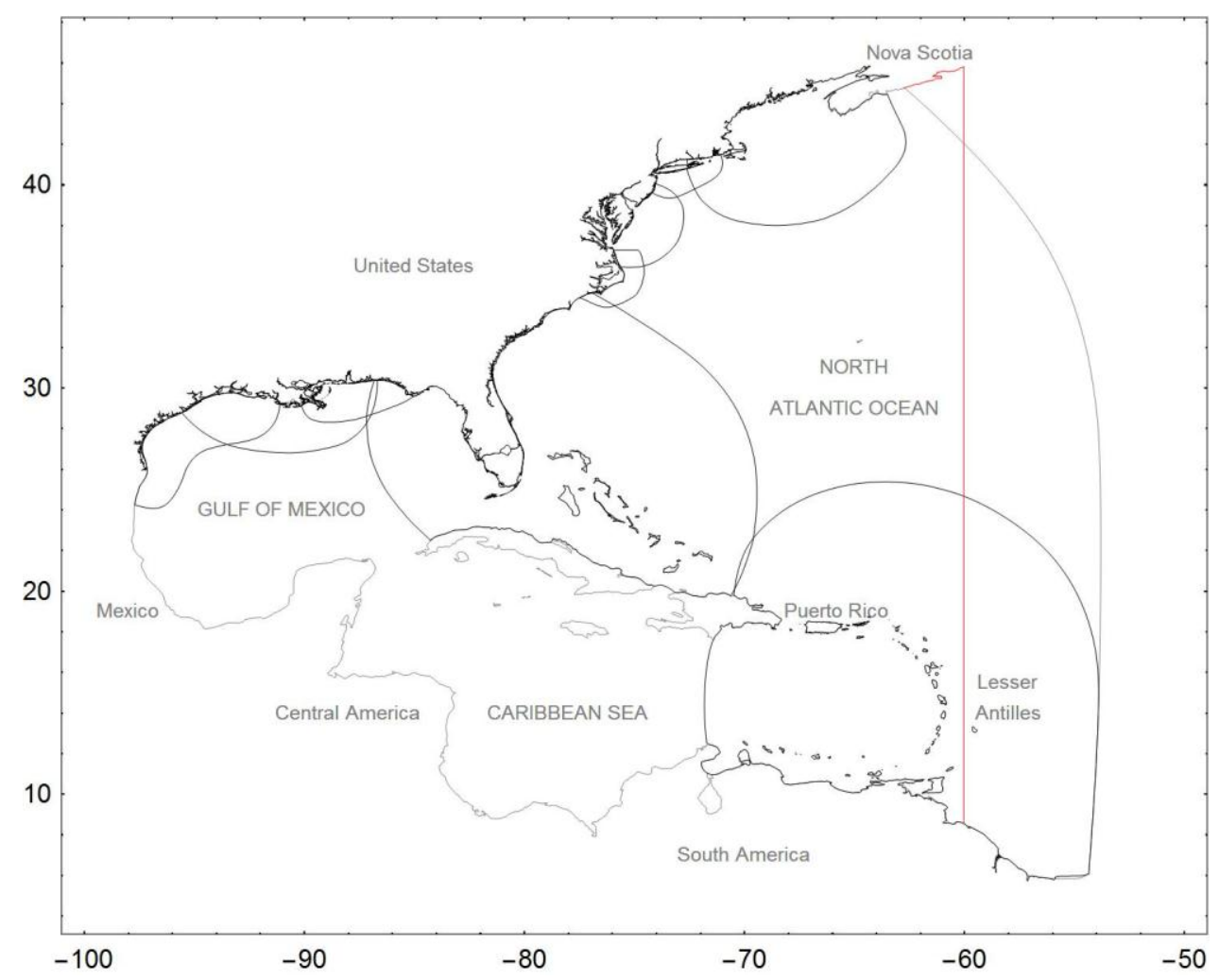

Figure 1. Location of new EC2001_extended model domain (shown in gray) compared to the traditional EC2001 boundary at the $60^{\circ} \mathrm{W}$ meridian (shown in red-remainder of shoreline is same as gray); and location of the nine VDatum domains (shown in black) used to update the coastal resolution and bathymetry in the EC2015 model. Note that the coarser gray shoreline is not visible underneath the black.

\subsubsection{Increased Coastal Resolution}

Each of the WNAT predecessors has gradually added more resolution along the coastline as data and computation capabilities were more readily available. However, this version marks a substantially increased level of coastal resolution for such a large study region. Recall from Table 1 that there are nearly 8 times the number of nodes in the EC2015 mesh when compared to the EC2001 mesh. 
Over the past 15 plus years, NOAA has undertaken an ambitious study of the United States coastline to create a tool for transformation between different vertical datums. The VDatum (Vertical Datum) tool provides a single source for accurately and easily transforming geospatial data among different tidal, orthometric and ellipsoidal vertical datums along the United States coast. It allows the user to combine data from different horizontal and vertical reference systems into a common system in order to create integrated digital elevation models. The interested reader is referred to the VDatum website for more general information about the VDatum tool and for regional publications [34].

In order to create accurate tidal datum fields for the coastal regions, a series of highly resolved coastal grids were developed for each region of the East and Gulf Coast for the United States, as well as Puerto Rico and the U.S. Virgin Islands. Figure 1 shows the boundaries of the nine VDatum grids that are presently available in the WNAT domain, with the remainder of the EC2001_extended boundary shown to clearly illustrate the regions where VDatum meshes were used. Individual reports [35-43] for each of these domains are available on the VDatum website.

Notice that there are several areas of overlap between these regional VDatum subdomains. For each of these overlaps, the individual grids were carefully pieced together in such a way as to preserve the source grid with the highest coastal resolution. For the shelf regions within these overlaps, a transitional mesh was created at an appropriate distance from the shoreline that smoothly blended the triangulations of the two VDatum meshes. Finally, the bathymetry from the highest resolution source was reapplied onto the new triangulation. This process was repeated for each of the overlapping areas. A comparison of the East Coast of the United States from North Carolina to Maine in the EC2015 model and the previous EC2001 model is shown in Figure 2. Notice the inclusion of more inland channels, rivers and islands; as well as a more detailed shoreline.
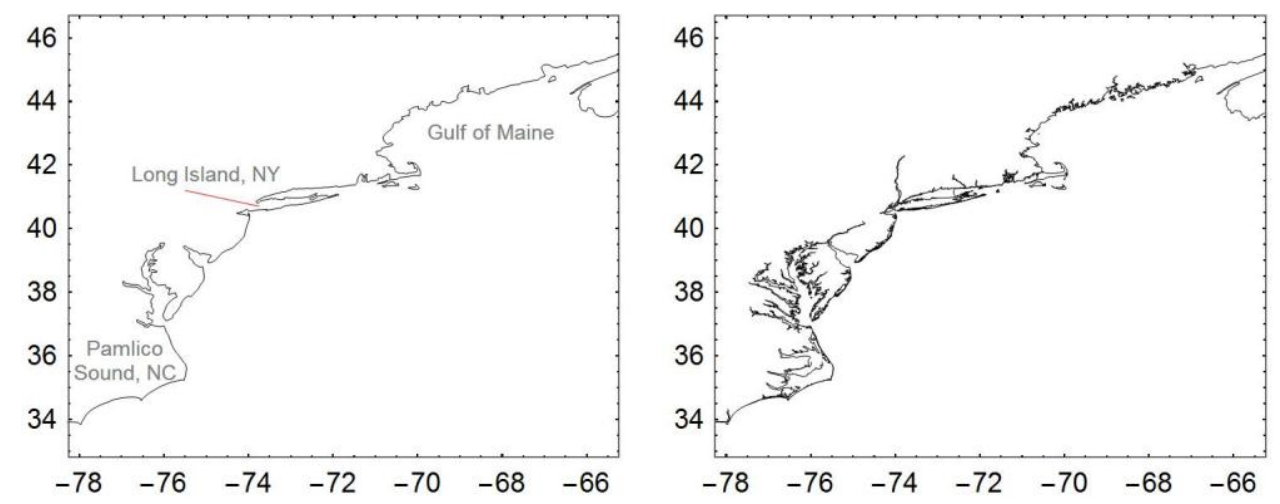

Figure 2. Comparison of coastal resolution in the EC2001 (left) and EC2015 (right) models from North Carolina to Maine.

It is important to note that the high-resolution meshes created for the VDatum project are in a Model Zero (MZ) vertical datum. The interested reader is referred to the VDatum Standard Operating Procedure manual [44]; but the basic idea is that small corrections are added/subtracted from the original charted bathymetry in an iterative manner until the simulation converges to a solution. The converged solution is verified against harmonic constituent data available within the region. This was necessary since the original bathymetric sources were all in different tidal datums and no tool existed to transform them into a unified vertical datum. The resulting vertical datum of the high resolution coastline is MZ. Although, model zero is not necessarily the same as mean sea level (MSL) due to non-linear dynamic effects, for our purposes, we have to assume that the VDatum coastline is approximately relative to MSL.

The next step was to replace the coastline of the newly created EC2001_extended mesh with this higher resolved coastline. During this step, we also compared localized truncation error analysis 
(LTEA) meshes of various resolution for the Florida South Atlantic Bight region as we transitioned from the VDatum coastline into the deeper waters [45]. While exploring the various options, it was discovered that several smaller channels along the Georgia and Carolina coasts had not been included in the original VDatum mesh. We decided not to pursue the LTEA meshing at this time, due to the large grid size and time involved to process the size functions. Instead, any hydrologically significant channels were added using NOAA National Ocean Service (NOS) charts and sounding data. However, because these areas were outside of the original VDatum "wet" area, the proper conversion from the NOS sounding datum (usually MLLW or MLW) to the common MSL datum was estimated from the nearest wet conversion points output from the VDatum tool, typically at the mouth of the channel. In order to extrapolate the conversions up the length of the new channels, the slope of the surrounding channel topography was examined and average slope values (for each stream reach) were used to "march" the sounding datum to MSL conversions upstream from the channel mouth. At points in the channel where the surrounding topographic slope changed, a new reach slope value was used to continue marching upstream.

\subsubsection{Updated Global Bathymetry}

Once the improved coastline was merged into the EC2001_extended model, the next task was to update the bathymetry of all the non-coastal U.S. waters, which had last been updated in 2001. Two different global bathymetry sources were examined: the $\mathrm{ETOPO}_{1} \mathrm{Global}_{\text {Relief }}$ Model from the National Geophysical Data Center and the SRTM30_PLUS model from the Scripps Institute of Oceanography.

The ETOPO 1 product is a 1 arc-minute global relief model of the Earth's surface. It integrates land topography and ocean bathymetry and was built from numerous regional and global data sets. Older two arc-minute and 5 arc-minute products are still available, although they have been deprecated by the latest model. The horizontal datum of $\mathrm{ETOPO}_{1}$ is WGS84 geographic and the vertical datum is sea level. "More specific vertical datums, such as mean sea level, mean high water, and mean low water, differ by less than the vertical accuracy of $\mathrm{ETOPO}_{1}(\sim 10 \mathrm{~m}$ at best), and are therefore effectively equivalent" [46]. Various methods are available for obtaining the $\mathrm{ETOPO}_{1}$ product from their website [47].

The SRTM30_PLUS product is a 30 arc-second global relief model of the Earth's surface, also derived from a wide variety of sources. However, rather than only being a compilation of existing bathymetric data sources, it also uses these data sources to modify global satellite bathymetry based on the latest altimeter-derived gravity models $[48,49]$. Depths are reported in meters and negative values indicate data points that are below sea level. Additionally, catalogs of the data sources and estimated errors in the depth and navigation for each point are available. Various methods of obtaining the data are available at their website [50].

After data was downloaded for each of these sources, the procedure was to create a bounding polygon of all water that was included in the various VDatum regional grids and only update the water that was outside of that polygon, see Figure 1 (all regions that are within the gray boundary but outside of the black boundaries were updated). This meant that most of the Gulf of Mexico and Caribbean coastline, including the southern coast of Cuba, Haiti and Jamaica had to be updated with global sources that were not necessarily meant to be used in shallow coastal regions. We compared both of the global sources and noticed that the $\mathrm{ETOPO}_{1}$ product resulted in a great deal of oscillations in shallower regions (checkerboard type pattern from one point to the next), particularly along the southern coast of Cuba. In comparison, the SRTM30_PLUS product did not suffer as much with this issue, although it did exhibit occasional oscillations in shallower regions. In general, both products were developed for deeper water not coastal areas and the resolution and depth accuracy is not high enough to adequately resolve shallow coastal waters-with average errors in the $10 \mathrm{~m}$ range, all depths below $10 \mathrm{~m}$ are suspect. Overall, it was decided to use a single source for the updated bathymetry and the SRTM30_PLUS database was used as it exhibited fewer oscillations in the shallower, near-shore 
regions. However, after interpolation of the global data set, there were nodes within the grid that were suspect-e.g., sharp change in bathymetry relative to surrounding nodes. The bathymetry at these suspect grid nodes was then hand-cleaned by interpolating from surrounding values in the mesh itself instead of directly from the global source. This removed most sharp oscillations along the non-US coastlines between topographic and bathymetric values, however, further inspection may reveal that some errors still exist.

\subsubsection{Updated Open Ocean Forcing}

Once an updated physical model had been developed for the entire WNAT region, it was necessary to extract tidal forcing information from available global tidal models at the open-ocean boundary. Since the last version of the East Coast ADCIRC tidal database in 2001, significant improvements have been made in the global tidal modeling community as well. Therefore, we compared two different choices for the boundary conditions: the TPXO7.2 model obtained from the Oregon State University Tidal Inversion Software (OTIS) and the Finite Element Solution FES2012 model from the French Tidal Group [33,51].

OTIS implements an efficient representer scheme for the general inversion calculation for tidal processing of TOPEX/Poseidon altimeter data going back to 2002. TPXO7.2 is a more recent version of a global model of ocean tides obtained from OTIS. The solution best fits, in a least-squares sense, the Laplace Tidal Equations and along-track averaged altimetry data [52,53]. TPXO products are updated as more altimetry and bathymetry data becomes available; since the beginning of the EC2001 project, they have since updated to TPXO8, but for consistency we wanted all of the model runs to have the same forcing so we continued to use TPXO7.2. Tides are provided as complex amplitudes of earth-relative sea-surface elevation for 13 constituents at a $1 / 4$ degree resolution for the global ocean; software and accompanying data can be downloaded from their website [33].

Similarly, the French Tidal Group utilizes a global unstructured grid to model the tidal barotropic equations in a spectral configuration and then employs representer data assimilation from long-term satellite altimetry data to correct the tidal signals. FES products are provided on a 1/16 degree resolution for 32 tidal constituents over the global ocean. The most recent version is FES2012, which was produced by Noveltis, Legos and CLS Space Oceanography Division and is distributed by Aviso [51,54].

After extracting the tidal constituent information from each of these databases, a visual comparison was made of the amplitude and phase information that would be used as input into the ADCIRC model. Since the TPXO products only have information for 13 constituents, it was decided to use these same thirteen harmonic constituents to force the ocean boundary (diurnal $-\mathrm{O}_{1} \mathrm{~K}_{1}$ $\mathrm{P}_{1} \mathrm{Q}_{1}$; semi-diurnal- $\mathrm{M}_{2} \mathrm{~S}_{2} \mathrm{~N}_{2} \mathrm{~K}_{2}$; quarter-diurnal- $\mathrm{M}_{4} \mathrm{MS}_{4} \mathrm{MN}_{4}$; and long term-Mf $\mathrm{Mm}$ ) in order to maintain a comparable forcing suite. In general, there were very few visual differences between these two models, particularly for the diurnal, semi-diurnal and long term constituents. What differences did exist were typically concentrated at the northern boundary near Nova Scotia (refer to Figure 1 for geographic locations within the WNAT domain). Similarly, among the quarter-diurnal constituents, most of the amplitude differences were focused along the boundary as it approached the coast of Nova Scotia. However, the phasing of the quarter-diurnal constituents was significantly different all along the boundary; note that the amplitudes of these constituents are often on the order of $10^{-3}$ to $10^{-2} \mathrm{~m}$. Additionally, the phasing of the $\mathrm{Q}_{1}$ constituent in each of the global products departed rapidly from each other as the boundary neared the Nova Scotia coast. A more quantitative comparison was made by calculating the maximum absolute difference in amplitude and phase over all 187 open ocean boundary nodes; these results are given in Table 2. 
Table 2. Maximum absolute differences along the entire EC2015 boundary between the TPXO7.2 and FES2012 global tidal database products.

\begin{tabular}{ccc}
\hline Constituent & Amplitude (cm) & Phase (Degrees) \\
\hline $\mathrm{O}_{1}$ & 1.28 & 20.20 \\
$\mathrm{~K}_{1}$ & 2.26 & 10.95 \\
$\mathrm{P}_{1}$ & 1.25 & 34.62 \\
$\mathrm{Q}_{1}$ & 0.55 & 122.14 \\
\hline $\mathrm{M}_{2}$ & 2.03 & 1.10 \\
$\mathrm{~N}_{2}$ & 0.44 & 6.39 \\
$\mathrm{~S}_{2}$ & 1.31 & 7.95 \\
$\mathrm{~K}_{2}$ & 1.00 & 10.01 \\
$\mathrm{M}_{4}$ & 0.86 & 34.49 \\
$\mathrm{MS}_{4}$ & 0.95 & 58.66 \\
$\mathrm{MN}_{4}$ & 0.11 & 16.22 \\
$\mathrm{Mf}$ & 0.21 & 39.85 \\
$\mathrm{Mm}$ & 0.06 & 6.67 \\
\hline
\end{tabular}

While interesting, this was not enough information to determine if one global model was better than the other. In the results section, we will present the actual ADCIRC harmonic differences due to the boundary forcing.

\subsubsection{Bottom Friction Assignment}

Finally, we examined three variations of the quadratic friction formulation for the EC2015 database: a constant $C F$ version and two variable friction formulations. For the variable formulations, we used a merged combination of the $C F$ values that had been developed for each of the VDatum regions and we also used the collaborative United States Geological Survey (USGS) usSEABED [55] database of core samples to assign appropriate Manning's $n$ friction values.

Of the nine VDatum grids that fall within the EC2015 model domain, five had a variable quadratic bottom friction scheme. It was not necessary to be as rigorous in combining these friction values, as the areas of grid overlap did not have any conflicting friction values. Therefore, each VDatum region was simply mapped onto the EC2015 model and then combined canonically.

The usSEABED database contains three files for each region: "EXT-numeric data extracted from lab-based investigations, PRS-numeric data parsed from word-based data and CLC - numeric data calculated from the application of models or empirical relationship files" [55]. Each of these datasets has limitations and describes the data in different ways; they can be combined to create a more extensive coverage of the seafloor characteristics. For the EC2015 study, we had to limit the richness of the dataset in order to make it tractable for such a large study area. Therefore a relatively simple approach wherein the grain distributions within the "Gravel", "Sand", "Mud" and "Clay" columns of the original usSEABEDS data were aggregated into a single description based upon percentages in each class. This created a verbal distinction only between gravel, sand and silt that did not worry about actual grainsize distributions. Each larger coastal area was then assigned a descriptive designation with an associated shelf Manning's $n$ value: muddy/silty: $n=0.015$, sandy: $n=0.022$ (upon visual examination, there were no large areas that were entirely gravel, just independent data points so no gravel appropriate Manning's $n$ values were assigned in this stage). After a region was classified by bed type, depth-dependent linear interpolation was used to assign Manning's $n$ values over each section of the coastal/shelf. For water depths between $5 \mathrm{~m}$ and $200 \mathrm{~m}$, the shelf value was assigned; for depths greater than $200 \mathrm{~m}$ the post-Ike "deep ocean" value of 0.012 was assigned; finally, for depths less than $5 \mathrm{~m}$, values were linearly interpolated from a value of 0.025 at zero depth to the shelf value at $5 \mathrm{~m}$ depth. This slightly larger zero-depth Manning's $n$ value is meant to take into account the impeded flow characteristics due to extremely shallow water. After this process was completed, smaller 
sub-regions were assigned estuary specific "shelf" values and very coarse sub-grids were defined over the sub-regions, then these sub-grids went through the linear depth interpolation process again with these new values. Only a few estuaries were assigned values different than their surrounding shelves. Table 3 provides the rough geographical shelf regions and specific estuaries that were used in this process, as well as the assigned shelf Manning's $n$ values.

Table 3. Geographic regions used for Manning's $n$ assignment from usSEABEDS data.

\begin{tabular}{ccc}
\hline Geographic Region & Bed Description & Assigned Shelf Value \\
\hline Louisiana/Texas & muddy/silty & 0.015 \\
Florida & sandy & 0.022 \\
Mexico/South America/Caribbean ${ }^{1}$ & sandy & 0.022 \\
Atlantic Coast & sandy & 0.022 \\
Delaware/Chesapeake Bays & silty & 0.015 \\
Westernmost New York Sound & silty & 0.015 \\
\hline${ }^{1}$ No data was available for these regions, so a general assumption was made.
\end{tabular}

This is a very simplified approach to assigning friction values given the rich dataset available. However, in the time available for the project, it was impossible to interpolate between each of the usSEABEDS data points and "smooth" the ensuing profile since there could be distances on the order of kilometers from a boulder site that was surrounded by sand. Without knowing the physical extents of the boulders, it is a judgement call how to transition from the one or two boulder indicated grainsizes to the surrounding sand bed. An area of future work would be an efficient interpolation scheme for such a diverse and scattered data set. Depending upon the water depth at an area of interest, it may not be as important as one might think however. If we look again at Equation (1) and note that initially eta $(t)=0$, then we can compute the equivalent quadratic friction coefficient, as ADCIRC does internally. This allows a visual comparison between the Manning's $n$ friction representation and the assigned VDatum friction representation. Figures 3 and 4 show regional views for the Gulf of Maine/New York Sound area and the Mississippi River delta area. For both Figures, panel (a) shows the bathymetric depth profile, panel (b) shows the assigned VDatum quadratic friction coefficients, panel (c) shows the simplified Manning's $n$ assignment, and panel (d) shows the computed equivalent quadratic friction coefficient associated with (a) and (c).

Note that in both figures, the scales for panels (b) through (d) are the same. However, owing to the difference in regional bathymetry, the bathymetry scales for panel (a) in each figure are different. For the deeper Atlantic coast region, notice that although there is some variation in the Manning's $n$ profile itself, the computed quadratic friction values do not show as much detail due to the overall deep bathymetry. Meanwhile, for the Louisiana region, the bathymetry scale is more abbreviated (from $0 \mathrm{~m}$ to $500 \mathrm{~m}$ with more detail in the first hundred meters) and there is more detail to the coastal $C F$ values due to the shallower nature of that region.

Due to the inherent simplifications in the Manning's $n$ assignments, a sensitivity study of the computed harmonic constituents to the assigned Manning's $n$ values was conducted. The originally assigned Manning's $n$ values were multiplied by factors of $90 \%$ and $110 \%$ and the resulting harmonic responses were compared. More details of this sensitivity study are given in the results section.

\subsubsection{Inclusion of ADCIRC Non-linear Advective Terms}

The final effort was to include the non-linear advective terms in the ADCIRC formulation; the interested reader is referred to [56] for details about the development of these terms and equations. In practice, these terms enter in by activating two flags in the input file. In past versions of the East Coast tidal database, the location of the open ocean boundary near the Lesser Antilles island chain caused instabilities if these terms were activated. Therefore, until the boundary was moved as part 
of this study, it was not possible to include fully non-linear advection and compare how the tidal response varied due to these terms.
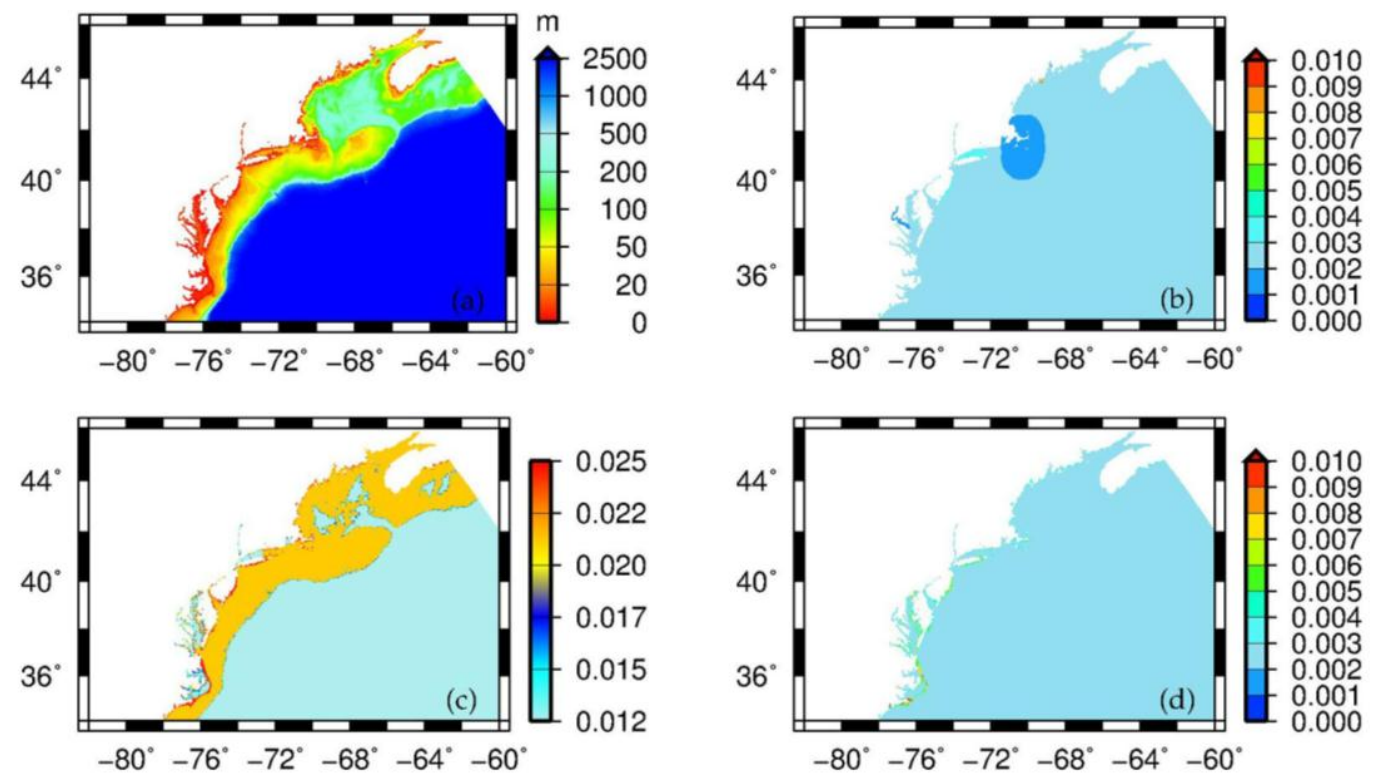

Figure 3. Comparison of bottom friction assignment for the Atlantic coastline from North Carolina to Maine: (a) bathymetry-scale from $0 \mathrm{~m}$ to $2500 \mathrm{~m}$, (b) assigned Vertical Datum (VDatum) friction coefficient $(C F)$ values, (c) assigned Manning's $n$ values and (d) computed $C F$ values from bathymetry and assigned Manning's $n$ values.
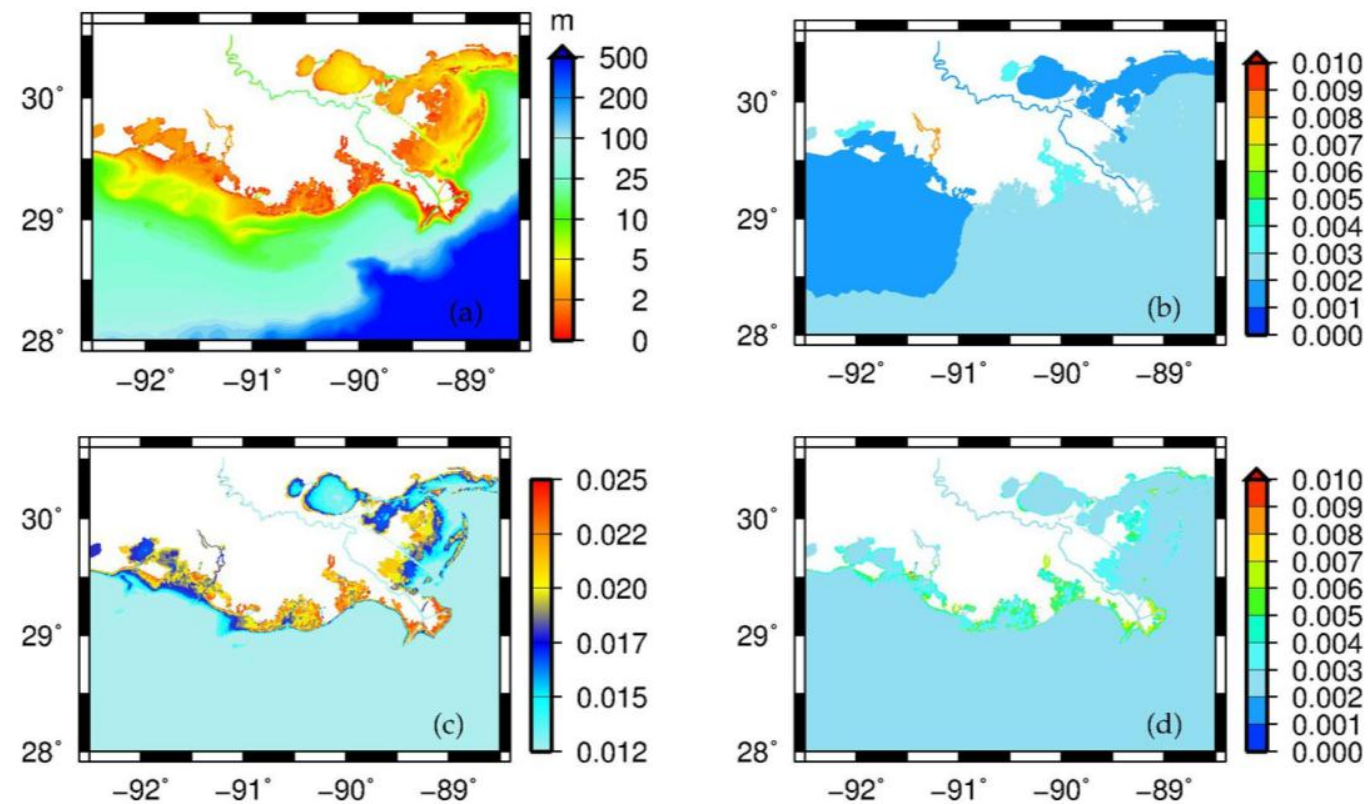

Figure 4. Comparison of bottom friction assignment for the Louisiana coastline: (a) bathymetry-scale from $0 \mathrm{~m}$ to $500 \mathrm{~m}$, (b) assigned VDatum CF values, (c) assigned Manning's $n$ values and (d) computed equivalent $C F$ values from bathymetry and assigned Manning's $n$ values.

\subsubsection{Summary of Tidal Database Improvements}

Six different areas of improvement have been presented for the EC2015 tidal database. Where possible, each model improvement was isolated to determine the accuracy improvement that was due only to that component of the project. However, the improved coastal resolution and 
updated bathymetry were lumped into the final EC2015 release and were not studied individually. Table 4 provides a summary of the simulations that were completed for this study; including the run designation, description, mesh domain, inclusion of the advection terms, friction scheme and boundary forcing. For the boundary forcing, the textual label indicates which global tidal database was used and the number indicates how many constituents were used (e.g., TPXO-10 indicates that the TPXO7.2 global database was used with only 10 constituents-recall that the quarter-diurnal constituents create instability in the EC2001 domain for long-term simulations). For clarity, when reporting results, labeling figures and during the discussion, the results will be referred to by their run designation.

Table 4. Summary of model parameters for the model simulations completed in this study.

\begin{tabular}{cccccc}
\hline $\begin{array}{c}\text { Run } \\
\text { Designation }\end{array}$ & Description & Grid & Advection & $\begin{array}{c}\text { Friction } \\
\text { Scheme }\end{array}$ & $\begin{array}{c}\text { Boundary } \\
\text { Forcing }\end{array}$ \\
\hline EC2001 & EC2001 extracted & EC2001 & Off & 0.0025 & TPXO-10 \\
EC2001-ext & EC2001 extended mesh & EC2001_ext & Off & 0.0025 & TPXO-10 \\
FES1 & FES 2012 & EC2015 & On & 0.0025 & FES-13 \\
OTIS1 & TPXO 7.2 & EC2015 & On & 0.0025 & TPXO-13 \\
OTIS3 & EC2015 release version & EC2015 & On & VDatum & TPXO-13 \\
OTIS3noadv & EC2015 advection off & EC2015 & Off & VDatum & TPXO-13 \\
OTIS4 & Manning $n$ & EC2015 & On & Manning's $n$ & TPXO-13 \\
OTIS5 & $90 \%$ Manning $n$ & EC2015 & On & $90 \%$ Manning & TPXO-13 \\
OTIS6 & $110 \%$ Manning $n$ & EC2015 & On & $110 \%$ Manning & TPXO-13 \\
\hline
\end{tabular}

${ }^{1}$ The textual part of the label indicates which global tidal database was used, while the number indicates how many constituents were included.

The EC2001 tidal database was rerun with the most recent version of ADCIRC to ensure that we could expect a fair comparison with the EC2015 results. Error analysis confirmed that the new version of ADCIRC was recreating the harmonic constituents from the 2008 updated tidal database [23]. In subsequent sections, all reference to the EC2001 model indicate that constituents were directly extracted from the previous version of the database at the same locations as the recent improvements. In order to test the affects due solely to the boundary location, a new input file that mimicked the 2008 update, but used the new expanded boundary, was created; this run designation is given by EC2001-ext. The only difference in the input file is that boundary forcing was extracted from the TPXO7.2 global tidal database at the new boundary node locations.

A series of runs using the final EC2015 model domain (boundary placement, updated bathymetry and improved coastal resolution all lumped together) were conducted; all seven of these used the full thirteen-constituent suite of boundary forcing and six of them include the advective terms. The OTIS1 and FES1 simulations differ only in whether the TPXO7.2 or FES 2012 global tidal databases were used for the boundary conditions; a constant bottom friction was utilized in order to isolate the boundary forcing. Additionally, four variable bottom friction runs were conducted to compare the harmonic response to various friction schemes; OTIS3 used the merged VDatum friction, OTIS4 used the original Manning's $n$ assignments, OTIS5 used the OTIS4 Manning's $n$ values scaled by $90 \%$, and OTIS6 scaled these by $110 \%$. Finally, in order to test the advective terms, the OTIS3noadv simulation mimics the OTIS3 simulation but with the advective terms turned off.

\subsection{Validation of the Improved ADCIRC Tidal Database}

Two sources of harmonic constituent data were used to validate the new EC2015 tidal database. The analysis techniques used to compute model errors are also discussed in this section. 


\subsubsection{Validation Data}

The Center for Operational Oceanographic Products and Services (CO-OPS) keeps a record of tidal benchmarks and harmonic data at stations throughout the United States [57]. Tidal harmonic data was available at 404 such stations in the EC2015 domain. Additionally, historical data from the International Hydrographic Organization (IHO) was used to provide wider coverage, specifically in the deeper regions beyond the continental shelves [58]. There is a higher measure of uncertainty in the IHO data, as information about the source of the constituents (e.g., length of analysis and data records) is not available; furthermore, the three-decimal digits precision of longitude and latitude coordinates used to locate the stations are sometimes insufficient to determine the physical location of the data collection. At the request of some of the participating countries, the bank was removed from public distribution in about 2002 [59]. Of the about $4190 \mathrm{IHO}$ stations available worldwide, 277 fall within the EC2015 domain. For skill assessment purposes, all 681 stations (404 from CO-OPS and 277 from IHO) were classified by regional location (Atlantic, Gulf of Mexico, Caribbean Sea), as well as coastal proximity versus deep ocean.

The overall locations of the available 681 data stations are shown in Figure 5a; while Figure 5b,c and Figure 6 show zoomed views of the various regions. In all of these figures, the gray boundary depicts the new EC2015 model domain while the green boundary depicts the old EC2001 model domain; the data locations from CO-OPS are shown in blue while IHO data locations are shown in red; data locations shown with a cyan circle surrounding them are not wet in the EC2001 domain and are excluded from any error comparisons that specifically say that only wet stations were used; finally, sample regional scatter plots are provided in Appendix B for the 10 stations that are shown with a black $X$ and indicated by station number.

Of these 681 stations, only 367 were considered wet in the EC2001 model, where by wet we mean that they are either within the domain itself (280) or were near enough to the boundary in the main water bodies that nearest neighbor data extraction (87) was valid. Stations that were far inland or within small channels are not extracted from the EC2001 database as they were not physically represented in the older database. All stations shown in Figures 5 and 6 without a cyan circle denote the location of these 367 stations where harmonics were extracted from the EC2001 database for comparison with the new EC2015 database. Appendix A provides a list of all 681 stations with the CO-OPS station designation (when applicable), lon/lat location, station name and assigned region (Table A1). Station numbers indicated with a single * are close enough to the boundary to use nearest element approximations within the EC2001 model, while those with a double ** are not located within the extents of the EC2001 model and are not used for statistics or station scatter plots when comparing results. Actual longitude and latitude coordinates were not shifted when extracting from the EC2001 database, as the nearest element is most likely where the station would have been manually shifted anyway.

\subsubsection{Validation Methods}

In order to determine which model best captured the tidal harmonic data at the available data stations, we looked at a variety of error measures. For each station, we examined scatter plots of measured and computed amplitude and phase for the eight primary tidal constituents $\left(M_{2}, S_{2}\right.$, $\mathrm{N}_{2}, \mathrm{~K}_{2}, \mathrm{O}_{1}, \mathrm{~K}_{1}, \mathrm{P}_{1}$ and $\mathrm{Q}_{1}$ ). Ideally, the computed and measured values would have a one-to-one correspondence. Scatter plots were also made that included all 681 stations for each of these eight constituents and a least-squares linear regression was computed. Additionally, comparison scatters showing both the EC2001 and EC2015 models for these eight constituents were created using the 367 wet stations in the EC2001 tidal database. 

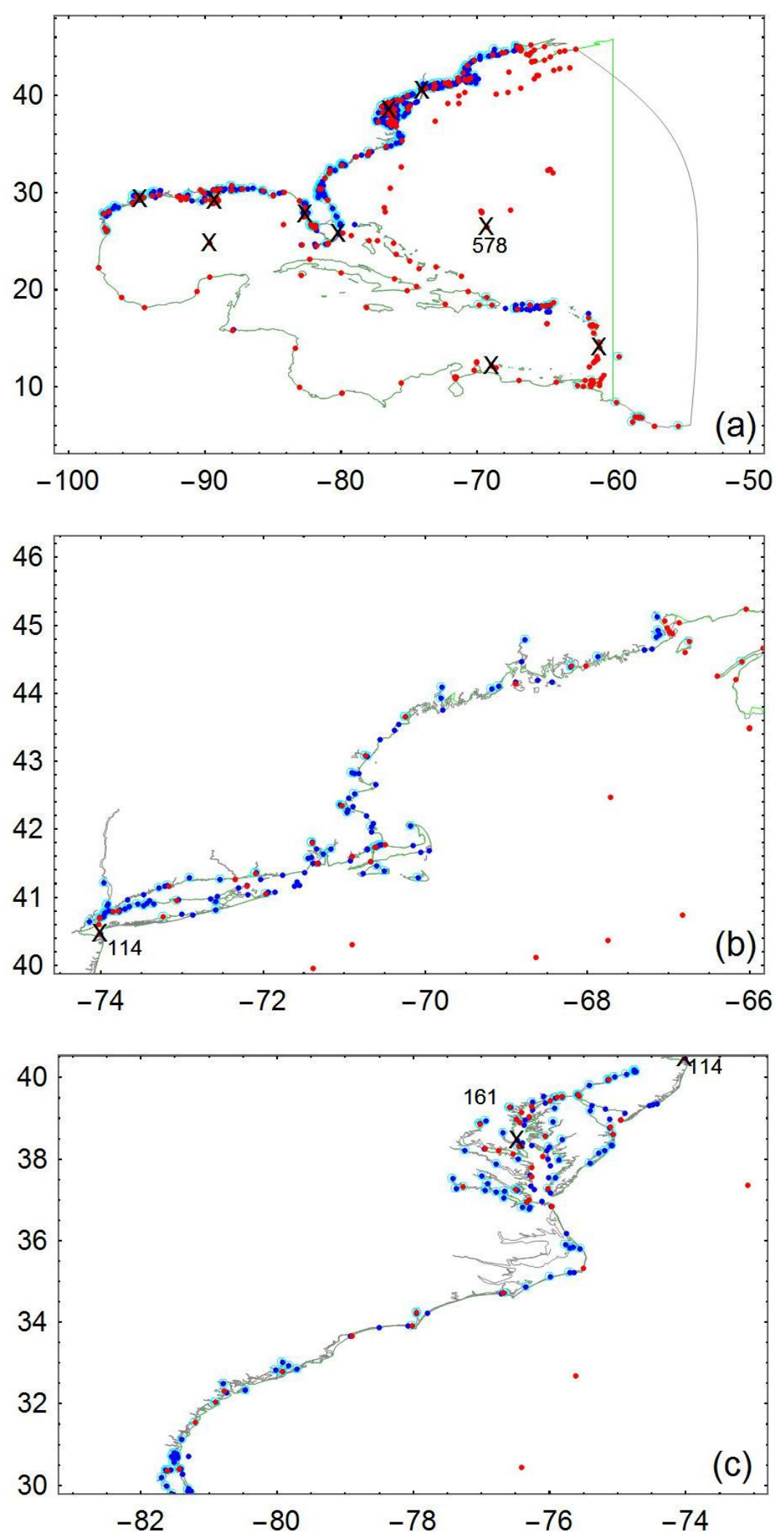

Figure 5. Locations for the stations available for validating the WNAT tidal databases: (a) global; (b) New York and Maine coast; and (c) Delaware down to Georgia. Blue points are from NOAA, red points are from IHO, cyan circles indicate stations that are in EC2015 (gray boundaries) but are not wet in EC2001 (green boundaries). Scatterplots are shown in Appendix B for points shown by an X. 

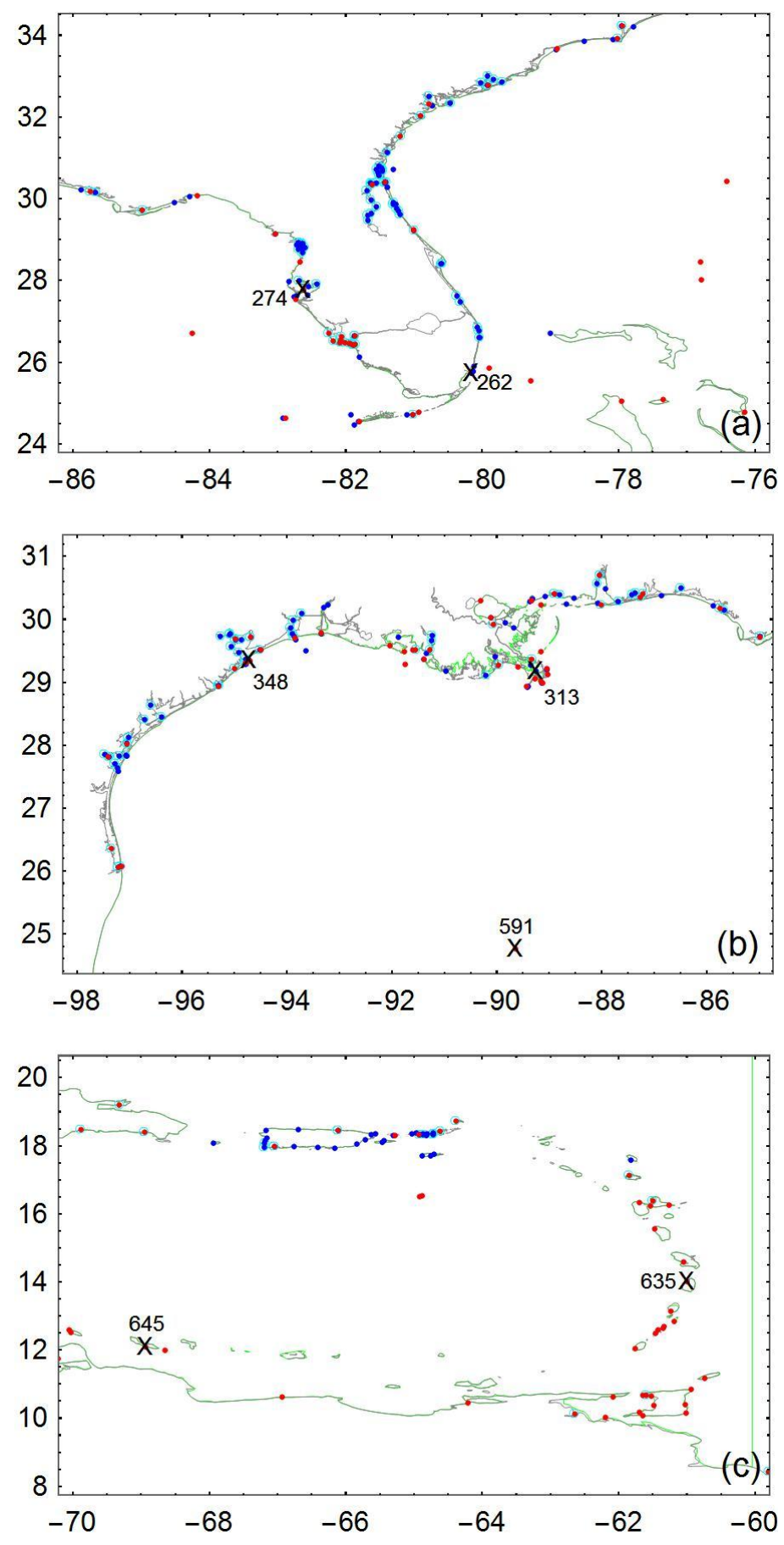

Figure 6. Locations for the stations available for validating the WNAT tidal databases: (a) Florida, (b) Gulf of Mexico and (c) Caribbean Sea. Blue points are from NOAA, red points are from IHO, cyan circles indicate stations that are in EC2015 (gray boundaries) but are not wet in EC2001 (green boundaries). Scatterplots are shown in Appendix B for points shown by an X.

In addition to these qualitative measures, three different error measures were calculated to quantify the skill of each model. For the phase, the mean absolute error was computed as

$$
M A E=\frac{1}{8 n p} \sum_{e=1}^{n p} \sum_{k=1}^{8} \mid \text { data }_{e, k}-\operatorname{model}_{e, k} \mid
$$


where errors are summed over the number of data points for a particular region $(e)$ as well as the number of constituents $(k)$. To calculate the mean errors for an individual constituent, the second sum would only be computed for $k=1$ and the 8 is removed from the denominator.

Due to some constituents having very small amplitudes, the mean relative error was computed for amplitudes only as

$$
M R E=\frac{1}{8 n p} \sum_{e=1}^{n p} \sum_{k=1}^{8} \frac{\mid \text { data }_{e, k}-\text { model }_{e, k} \mid}{\text { data }_{e, k}}
$$

where the same summation rules apply. Note that if the errors are on the same order of magnitude as the data, the relative errors will be close to $100 \%$. Additionally, a composite root mean square (RMS) error, combining the phase and amplitude error for each constituent into a single error metric, was calculated at each station as

$$
A_{E}=\sqrt{0.5\left(A_{m}^{2}+A_{o}^{2}\right)-A_{m} A_{o} \cos \left(\pi\left(h_{m}-h_{o}\right) / 180\right)}
$$

where $A_{m}$ is the modeled amplitude in meters, $A_{o}$ is the observed amplitude in meters, $h_{m}$ is the modeled phase (degrees GMT) and $h_{0}$ is the observed phase (degrees GMT). As before, the mean errors are calculated by summing over the number of data points for any particular region as well as the number of constituents,

$$
\text { MeanRMSE }=\frac{1}{8 n p} \sum_{e=1}^{n p} \sum_{k=1}^{8}\left(A_{E}\right)_{e, k}
$$

In order to compare the skill of the new EC2015 model versus the previous EC2001 database, harmonic constituents were extracted from the 2001 database (2008 updated) at the stations that were within (or close enough to) the bounds of the EC2001 model. Mean errors were then computed for both databases at those 367 locations. However, mean errors were also calculated at all 681 stations for the new EC2015 database. Table 5 provides the total number of stations in each region that were used for statistics for each model; parenthetical numbers include only the stations that were physically within the EC2001 domain, not the nearest neighbors.

Table 5. Total number of validation stations available in each region for the most recent East Coast models.

\begin{tabular}{cccccc}
\hline Model & Atlantic Ocean & Deep Stations $^{2}$ & Gulf of Mexico & Caribbean & Global \\
\hline EC2001 & $204(151)^{1}$ & 31 & $90(74)$ & $73(55)$ & $367(280)$ \\
EC2015 & 414 & 31 & 178 & 89 & 681 \\
\hline
\end{tabular}

${ }^{1}$ Numbers in parentheses indicate how many were actually within the EC2001 domain while the first number includes those stations approximated with nearest neighbors. ${ }^{2}$ The deep stations are also included in the Atlantic and Gulf of Mexico regional numbers.

\section{Results}

\subsection{Results for the Various Improvements}

In this section some of the model improvements are examined independently to determine how effective they are at increasing the tidal constituent accuracy. For brevity, only the regional mean RMS error comparisons are provided here. Full error analysis, as described in Section 2.3.2, will be provided in Section 3.2 when the EC2001 model is compared to the final release EC2015 model. Figure 7 presents the regional mean RMS errors for all nine simulations that were previously presented in Table 4 . These mean errors were computed using only the 367 wet stations that are common to all model domains. 


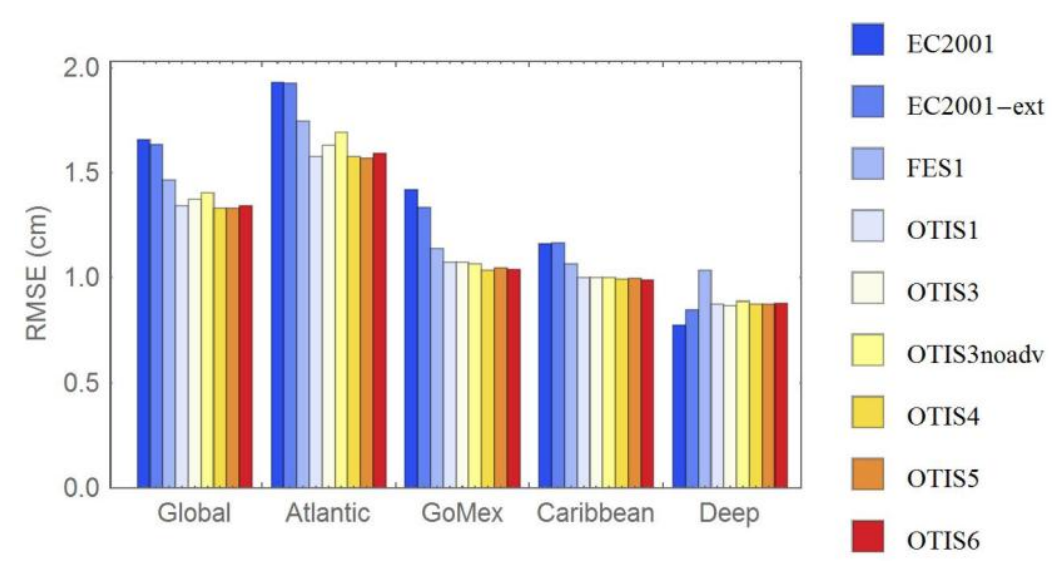

Figure 7. Comparison of regional root mean square (RMS) errors using the 367 wet stations for all nine study simulations summarized in Table 4.

\subsubsection{Boundary Placement}

As described in Section 2.2.1, the open ocean boundary has been moved out away from the Lesser Antilles Islands and the historical $60^{\circ} \mathrm{W}$ meridian that has been used for over 25 years. In order to test how much of an affect the new boundary placement has on the extracted harmonic constituents, the new EC2001_extended model was run with an identical input file as was used for the 2008 updates to the EC2001 tidal database, ec2001_v2e, [23]: a larger time step of $5.0 \mathrm{~s}$ is possible with these coarser meshes, the non-linear advective terms were turned off and only 10 forcing frequencies were used on the open boundary - the three quarter-diurnal constituents were not used in order to match the EC2001 simulation. All other parameters are as described in Section 2.1.2.

Concentrating only on the EC2001 and EC2001-ext results in Figure 7, we note that simply moving the boundary out away from the Lesser Antilles does not significantly improve the overall accuracy, although it does help the stability of the model. The Atlantic and Caribbean regional errors are unchanged, while the global errors are only slightly reduced. A moderate error reduction is realized in the Gulf of Mexico region and the deep stations actually have slightly higher mean errors.

\subsubsection{Comparison of Open Ocean Boundary Forcing}

Two different global tidal databases have been examined as input to the EC2015 model: FES12 and TPXO7.2. Looking at the FES1 and OTIS1 bars in Figure 7, we note that for all regions the OTIS1 simulation has less error than the FES1 simulation; these error reductions are most significant in the Atlantic region and deep water stations. Although the differences are rather small, it is obvious that the TPXO global database is providing more accurate results than the FES12 database.

\subsubsection{Comparison of Bottom Friction Schemes}

In this study, three different bottom friction schemes are compared: constant $C F=0.0025$, VDatum quadratic friction coefficients and Manning's $n$ formulation with $n$ values estimated using the USGS usSEABEDS data. Due to the simplified assignment of the Manning's $n$ values, sensitivity to the actual Manning's $n$ specification was also examined.

Looking at the mean RMS errors for the OTIS1 through OTIS6 simulations (ignoring OTIS3noadv) in Figure 7, we note that there is actually very little difference in the mean errors for the Gulf of Mexico, Caribbean and Deep stations for any of the five friction simulations. Furthermore, we see that there is also little difference in the three Manning's $n$ simulations (OTIS4 through OTIS6) in any of the regions. This is encouraging as it means that there is very little to no model sensitivity to small perturbations in the Manning's $n$ values. Although a rather simplified approach for assigning these values was used, we should not be too concerned with the approach, assuming that representative values for each 
region were chosen carefully. Finally, we note that the VDatum friction scheme (OTIS3) has slightly higher mean errors in the Atlantic region.

Examination of the individual constituents indicate that there is very little difference in the mean errors for the various friction simulations. The exception is the $\mathrm{M}_{2}$ constituent which has slightly higher errors of about $0.3 \mathrm{~cm}$ for the OTIS3 simulation than all of the others. If one were to look at scatter plots of individual stations, then more substantial differences could be detected; however, on average, most constituents are insensitive to small changes in the bottom friction. Given the simplifications of the Manning's $n$ assignments and the prior validation of the VDatum $C F$ values during the VDatum model development, for this release (EC2015) we have chosen to implement the VDatum friction values.

\subsubsection{Inclusion of Advective Terms}

Finally, when examining the OTIS3 and OTIS3noadv error bars, we note that very little difference can be seen between the errors in the Gulf of Mexico and Caribbean regions. However, there are noticeable differences in the Atlantic Ocean and Deep stations, with the OTIS3noadv bars having slightly higher error than their counterpart. From this, we conclude that the addition of the advective terms does reduce the mean errors in the tidal constituent harmonics, particularly in the Atlantic coastal regions. While not shown here, it is noteworthy that these differences are more significant when all 681 stations are used to calculate the mean errors; this is due to the higher percentage of stations in the shallower coastal regions and narrow channels where the advective processes are more dominant.

\subsection{Comparison of EC2015 and EC2001}

For the EC2015 tidal database release, the VDatum friction formulation and TPXO7.2 boundary forcing with all 13 constituents was used; all other model input parameters are as given above in Section 2.1.2. For results and discussion, when we refer to EC2001 we mean the updated 2008 version [24]. Scatter plots of computed versus measured amplitudes and phases (and their linear best-fit) for the EC2001 and EC2015 databases are shown in Figure 8 for the dominant diurnal and semi-diurnal tidal signals: $\mathrm{K}_{1}$ and $\mathrm{M}_{2}$. Additionally, Table 6 provides the best fit statistics for all eight primary constituents at the 367 validation stations that are common to both databases.

Table 6. Summary of best-fit linear statistics for the 367 common validation stations in the EC2001 and EC2015 tidal databases.

\begin{tabular}{|c|c|c|c|c|c|c|c|c|c|}
\hline \multicolumn{10}{|c|}{ Harmonic Amplitudes } \\
\hline Model & Best-fit & $\mathrm{O}_{1}$ & $K_{1}$ & $\mathbf{P}_{1}$ & $\mathrm{Q}_{1}$ & $\mathbf{M}_{2}$ & $\mathrm{~S}_{2}$ & $\mathrm{~N}_{2}$ & $\mathrm{~K}_{2}$ \\
\hline \multirow{2}{*}{ EC2001 } & Slope & 1.082 & 1.053 & 0.989 & 1.065 & 1.025 & 0.938 & 0.916 & 1.013 \\
\hline & $R^{2}$ & 0.973 & 0.964 & 0.956 & 0.959 & 0.989 & 0.959 & 0.971 & 0.943 \\
\hline \multirow[b]{2}{*}{ EC2015 } & Slope & 1.054 & 1.024 & 1.014 & 1.106 & 1.010 & 0.946 & 0.911 & 1.027 \\
\hline & $R^{2}$ & 0.984 & 0.978 & 0.964 & 0.960 & 0.996 & 0.975 & 0.980 & 0.964 \\
\hline \multicolumn{10}{|c|}{ Harmonic Phases } \\
\hline Model & Best-fit & $\mathrm{O}_{1}$ & $\mathbf{K}_{1}$ & $\mathbf{P}_{1}$ & $\mathrm{Q}_{1}$ & $\mathbf{M}_{2}$ & $S_{2}$ & $\mathbf{N}_{2}$ & $\mathbf{K}_{2}$ \\
\hline \multirow{2}{*}{ EC2001 } & Slope & 0.988 & 0.995 & 0.981 & 0.967 & 0.980 & 0.959 & 0.976 & 0.960 \\
\hline & $R^{2}$ & 0.994 & 0.995 & 0.995 & 0.992 & 0.972 & 0.963 & 0.979 & 0.946 \\
\hline \multirow{2}{*}{ EC2015 } & Slope & 0.983 & 0.975 & 0.988 & 0.955 & 0.986 & 0.951 & 0.986 & 0.964 \\
\hline & $R^{2}$ & 0.997 & 0.997 & 0.997 & 0.993 & 0.984 & 0.974 & 0.987 & 0.962 \\
\hline
\end{tabular}

For a perfect fit of the validation data, both the slope and $R^{2}$ values would have a value of unity. Notice that although the slope may not be improved for all eight constituents, the $R^{2}$ value is closer to unity for all of them, indicating a tighter distribution. The larger apparent scatter in the diurnal amplitudes is due to their much smaller magnitudes, while the scatter in the semi-diurnal phases resides mostly in the Caribbean and Gulf of Mexico stations where the predominant constituents are 
diurnal. Additionally, many of the CO-OPS validation stations on Puerto Rico have data records that are significantly less than one year.

Similarly, if we look at scatter plots of individual stations, we can compare how each of the databases performs for that point. Since there are 681 validation stations, only a few representative stations are provided herein. Figures B1-B5 in Appendix B provide plots for the 10 stations that were shown by a black $X$ in Figures 6 and 7; plots are grouped together by region: Atlantic coast, Florida coast, Gulf of Mexico, Caribbean Sea and deep ocean stations. In order to illustrate the station differences due to the friction formulation, results for both the VDatum and Manning's $n$ friction formulations are shown in these plots. Other than the bottom friction itself, all other ADCIRC parameters are the same for these two data sets. First, note that the different friction formulations typically affect the amplitude response of the model more than the phase (with the exception of station 313 at Pilottown, LA and station 645 at Curacao Willemstad). Recall that there are no river boundary conditions in these simulations, they are purely tidally driven. Therefore, stations such as Pilottown, LA that are located on a major river will not exhibit the proper harmonic response as they do not include the effects of riverine flow. Generally, the new EC2015 model is within the 5\%-10\% error bars for amplitudes and $10^{\circ}-20^{\circ}$ error bars for phase. For stations that are not, such as station 348 at Galveston Bay Entrance, where some constituents are overestimated while others are underestimated, a thorough examination of the nearby bathymetry may be warranted. While every effort was made to use the most recent bathymetry data available by incorporating the VDatum models, for some regions the only available NOS charts can be around 100 years old.
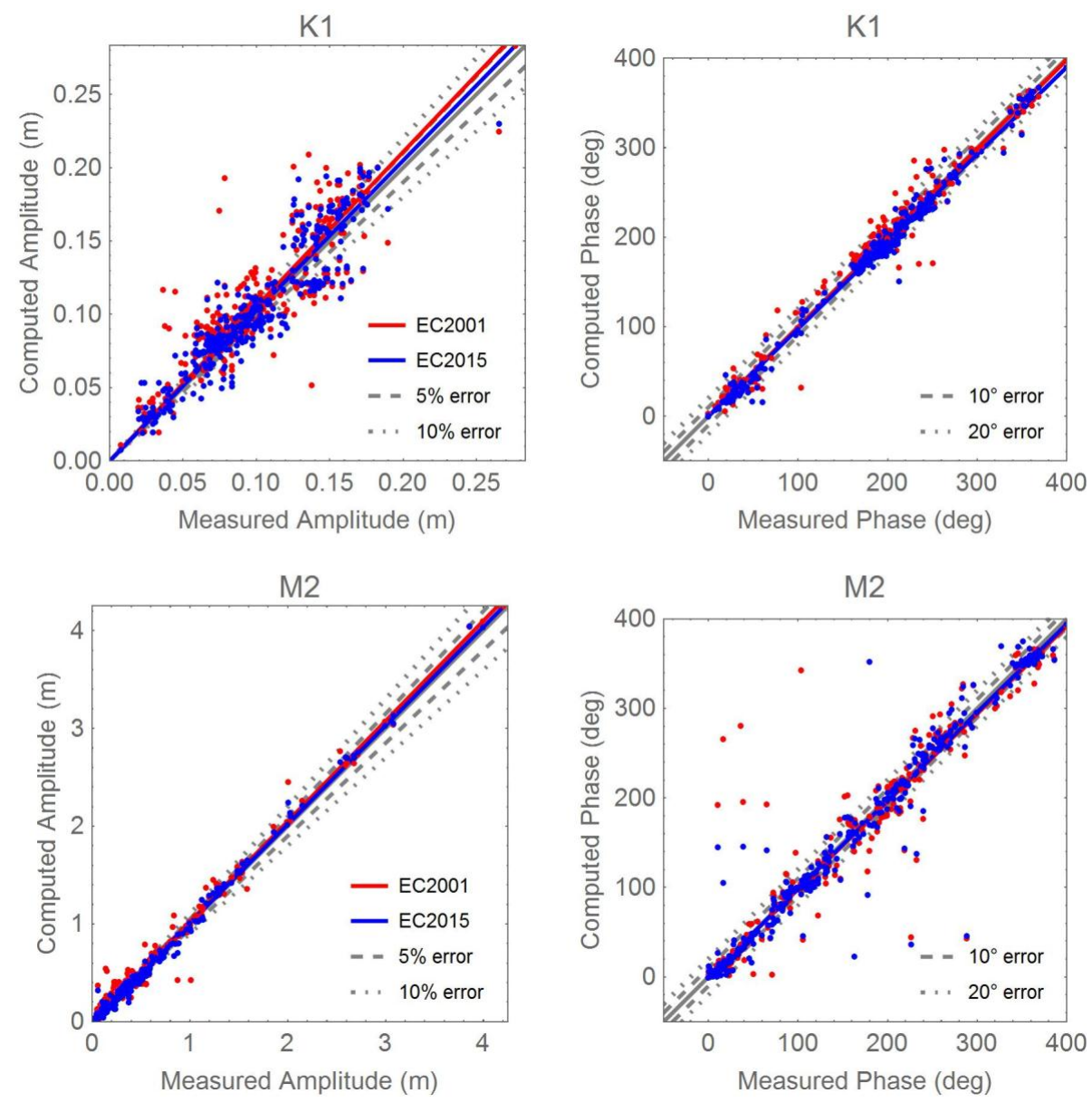

Figure 8. Comparison of scatter plots for the dominant constituents $\left(\mathrm{K}_{1}, \mathrm{M}_{2}\right)$ for the EC2001 and EC2015 tidal databases using the 367 common validation data stations. 
It is also instructive to see if there are sub-regional patterns in the errors (at the individual water body scale), which can help to guide future efforts at improving the tidal database. Plots of relative amplitude and absolute phase errors for the EC2015 model at each of the 681 stations are provided in Figures $\mathrm{C} 1-\mathrm{C} 7$ in Appendix $\mathrm{C}$ for the $\mathrm{M}_{2}$ and $\mathrm{K}_{1}$ constituents (same zoom views given in Figures 5 and 6). Plots are only provided for the dominant constituent in the sub regions: Gulf of Maine, Atlantic coast and Florida- $\mathrm{M}_{2}$ and Gulf of Mexico and Caribbean Sea- $-\mathrm{K}_{1}$. Points shown in blue are underestimating the amplitudes (or exhibit a phase lag), while points shown in red are overestimating (exhibit a phase lead). The symbol shapes indicate to what degree the model is over/under estimating; we would like to see amplitude errors less than $10 \%$ and phase errors less than $20^{\circ}$. Several general trends can be gleaned from these plots:

- The $\mathrm{M}_{2}$ amplitudes in the Gulf of Maine are slightly overestimated (generally less than 5\% but a few as high as $20 \%$ ) while those at the east end of Long Island Sound are overestimated about $10 \%-20 \%$. Meanwhile stations along the remainder of the Atlantic coast down through Florida are underestimated by $5 \%-10 \%$ on average, with a few isolated stations overestimating. The Chesapeake Bay and Florida Key regions have several stations that are underestimated by more than $10 \%$. For the 681 stations, 309 or roughly $45 \%$ of them have relative amplitude errors above the desired 10\% threshold; most of these lie within the Gulf Coast and Caribbean regions where the semi-diurnal amplitudes are small and the remaining are fairly evenly distributed throughout the domain.

- The $\mathrm{M}_{2}$ phases are generally lagged for the entire Atlantic coast and Florida region, with the exception of the Gulf of Maine (which exhibits slight $0 \%-5 \%$ phase leads). The most severe phase lags are often in the upper reaches of the estuaries, embayments and rivers. Of the 404 stations, only 111 (or $16 \%$ ) have absolute phase errors greater than the desired $20^{\circ}$; most of these lie within the Chesapeake Bay, Gulf Coast and Caribbean regions.

- The amplitudes for the diurnal $\mathrm{K}_{1}$ constituent are generally overestimated along the Gulf coasts and the Caribbean, although there are a few stations that are underestimated. While many of the Gulf of Mexico stations are outside of the desired 10\% range, the majority of the Caribbean Sea stations are below this threshold. A higher number of the 681 stations $(57 \%)$ fall outside of the desired $10 \%$ relative amplitude error range- of these stations, $60 \%$ are along the Atlantic coast where the semi-diurnal tides usually dominate and 30\% are in the Gulf of Mexico with the remainder in the Caribbean Sea.

- Meanwhile, the phases for the $\mathrm{K}_{1}$ constituent generally exhibit a phase lag in the Gulf of Mexico and Caribbean Sea basins and are typically more accurate. However, the stations along the northern Texas coast often exhibit phase leads. Only $8 \%$ fall outside of the desired $20^{\circ}$ error range and two-thirds of those are along the Atlantic coast.

Finally, mean RMS errors for regions are shown in Figure 9, while mean absolute phase errors and mean relative amplitude errors are provided in Table 7 . Looking primarily at the 367 validation stations that are common to both databases (blue diamonds for EC2001 and red circles for EC2015), we can draw several general conclusions.

- Globally, the greatest overall RMS improvement is realized in the M2 constituent $\left(1.1 \mathrm{~cm}\right.$ reduction). All of the constituents (except Q1) exhibit $2^{\circ}-4^{\circ}$ reductions in mean absolute phase error and $1 \%-7 \%$ reductions in mean relative amplitude errors. Overall, there is a $4 \%$ reduction in amplitude errors and about $2^{\circ}$ in phase errors.

- For the Atlantic region, RMS error reductions of about $0.3 \mathrm{~cm}$ are gained in the $\mathrm{O}_{1}, \mathrm{~K}_{1}$ and $\mathrm{N}_{2}$ constituents and $1.4 \mathrm{~cm}$ for the $\mathrm{M}_{2}$ constituent. In general, all of the constituents have $2^{\circ}-3^{\circ}$ reductions in mean absolute phase errors. However, the $Q_{1}$ and $K_{2}$ constituents actually have higher errors in the $2^{\circ}-3^{\circ}$ range. Additionally, with the exception of $Q_{1}$ which is roughly unchanged, the diurnal constituents exhibit 1 to $8 \%$ reductions in relative amplitude errors while the semi-diurnal have $3 \%-8 \%$ reductions in error. 
- For the Gulf of Mexico, the greatest RMS error improvements are in the $\mathrm{O}_{1}$ and $\mathrm{K}_{1}(0.5 \mathrm{~cm})$, $\mathrm{M}_{2}(1.0 \mathrm{~cm})$ and $\mathrm{S}_{2}(0.3 \mathrm{~cm})$ constituents. Mean absolute phase errors are improved by $1^{\circ}-3^{\circ}$ for the diurnal constituents and $3^{\circ}-11^{\circ}$ for the semi-diurnal (with the exception of $S_{2}$ which exhibits little change). Meanwhile, mean relative amplitude errors are reduced by $2 \%-6 \%$ for the diurnal constituents and by $8 \%-13 \%$ for the semi-diurnal (with the exception of $\mathrm{Q}_{1}$ and $\mathrm{M}_{2}$ which exhibit error increases of $2 \%-3 \%$ ).

- For the Caribbean region, there are minor RMS error improvements of about $0.2 \mathrm{~cm}$ in the $\mathrm{O}_{1}$, $\mathrm{K}_{1}$ and $\mathrm{S}_{2}$ constituents and $0.4 \mathrm{~cm}$ for $\mathrm{M}_{2}$ while most of the other constituents are reduced by less than $0.1 \mathrm{~cm}$. Mean absolute phase errors increase by $1^{\circ}-2^{\circ}$ for the diurnal constituents and decrease by $2^{\circ}-9^{\circ}$ for the semi-diurnal constituents. Mean relative amplitude errors decrease by $2 \%-11 \%$ for the diurnal constituents and $2 \%$ for $\mathrm{M}_{2}$; while $\mathrm{N}_{2}$ and $\mathrm{K}_{2}$ increase by about $1 \%$. Given these erratic trends, it is instructive to note that the data records used at CO-OPS to generate the harmonic constituent data in the U.S. Virgin Islands and Puerto Rico are often as small as 29 days.
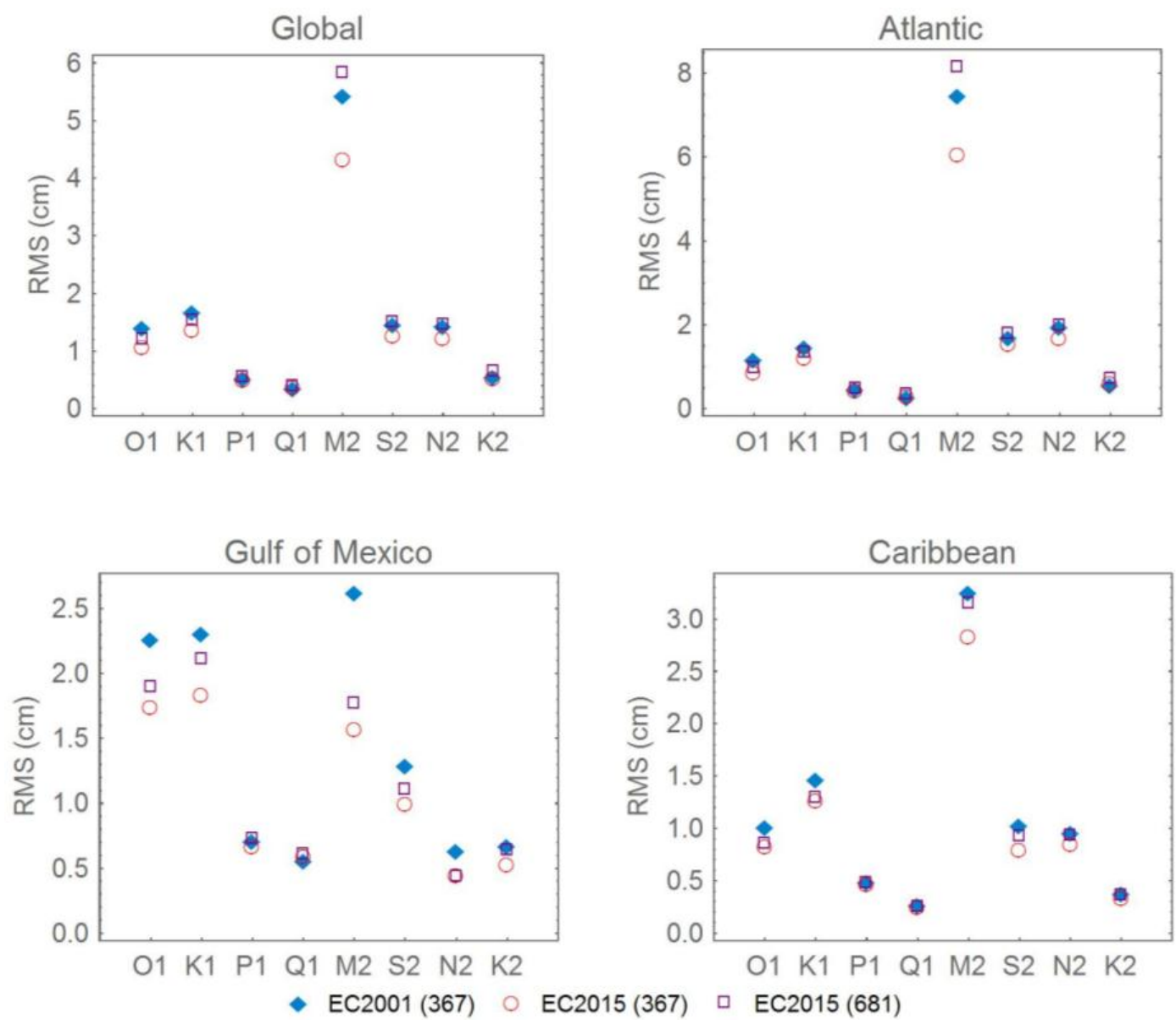

Figure 9. Mean RMS errors (cm) in harmonic constituents for the EC2001 and EC2015 ADCIRC tidal databases for each region of the WNAT model domain. 
Table 7. Comparison of mean relative amplitude and mean absolute phase errors by region for each of the eight primary harmonic constituents and summed over all eight constituents for the EC2001 and EC2015 tidal databases: only common 367 wet validation stations used in the summations.

\begin{tabular}{|c|c|c|c|c|c|c|c|c|}
\hline \multicolumn{9}{|c|}{ Mean Relative Amplitude Errors (\%) } \\
\hline \multirow{2}{*}{ Constituent } & \multicolumn{2}{|c|}{ Entire Domain } & \multicolumn{2}{|c|}{ Atlantic Ocean } & \multicolumn{2}{|c|}{ Gulf of Mexico } & \multicolumn{2}{|c|}{ Caribbean Sea } \\
\hline & EC2001 & EC2015 & EC2001 & EC2015 & EC2001 & EC2015 & EC2001 & EC2015 \\
\hline $\mathrm{O}_{1}$ & 18.99 & 12.12 & 18.68 & 10.35 & 18.11 & 15.59 & 20.91 & 12.74 \\
\hline $\mathrm{K}_{1}$ & 19.51 & 14.02 & 18.93 & 12.96 & 18.42 & 15.97 & 22.45 & 14.56 \\
\hline$P_{1}$ & 18.46 & 17.27 & 17.04 & 16.19 & 18.25 & 17.42 & 22.83 & 20.23 \\
\hline $\mathrm{Q}_{1}$ & 21.79 & 21.00 & 19.89 & 20.34 & 21.26 & 24.56 & 28.86 & 17.50 \\
\hline $\mathrm{M}_{2}$ & 23.39 & 20.65 & 13.39 & 8.50 & 38.31 & 39.81 & 32.95 & 30.98 \\
\hline $\mathrm{S}_{2}$ & 23.77 & 18.08 & 17.01 & 12.76 & 37.83 & 24.54 & 25.33 & 25.06 \\
\hline $\mathrm{N}_{2}$ & 22.57 & 19.20 & 14.76 & 11.97 & 39.76 & 31.60 & 23.66 & 24.72 \\
\hline $\mathrm{K}_{2}$ & 31.40 & 25.06 & 20.01 & 11.78 & 61.82 & 54.28 & 33.73 & 34.71 \\
\hline All 8 & 22.40 & 18.29 & 17.42 & 12.98 & 30.90 & 27.23 & 26.16 & 22.49 \\
\hline \multicolumn{9}{|c|}{ Mean Absolute Phase Errors (deg) } \\
\hline \multirow{2}{*}{ Constituent } & \multicolumn{2}{|c|}{ Entire Domain } & \multicolumn{2}{|c|}{ Atlantic Ocean } & \multicolumn{2}{|c|}{ Gulf of Mexico } & \multicolumn{2}{|c|}{ Caribbean Sea } \\
\hline & EC2001 & EC2015 & EC2001 & EC2015 & EC2001 & EC2015 & EC2001 & EC2015 \\
\hline $\mathrm{O}_{1}$ & 10.37 & 8.49 & 11.02 & 9.41 & 9.30 & 6.53 & 9.87 & 8.34 \\
\hline $\mathrm{K}_{1}$ & 8.87 & 7.47 & 9.21 & 7.73 & 8.44 & 6.27 & 8.49 & 8.25 \\
\hline$P_{1}$ & 9.59 & 7.66 & 9.52 & 7.55 & 8.90 & 6.71 & 10.69 & 9.17 \\
\hline $\mathrm{Q}_{1}$ & 13.70 & 14.22 & 15.22 & 17.03 & 9.85 & 8.20 & 14.83 & 14.58 \\
\hline $\mathrm{M}_{2}$ & 15.49 & 12.19 & 9.53 & 7.24 & 23.53 & 19.05 & 22.21 & 17.55 \\
\hline $\mathrm{S}_{2}$ & 16.24 & 14.35 & 9.40 & 8.53 & 26.62 & 22.81 & 22.64 & 20.27 \\
\hline $\mathrm{N}_{2}$ & 17.16 & 12.98 & 10.40 & 7.53 & 27.45 & 17.94 & 23.95 & 22.72 \\
\hline $\mathrm{K}_{2}$ & 19.11 & 19.57 & 12.06 & 15.72 & 30.19 & 25.05 & 29.17 & 25.67 \\
\hline All 8 & 13.76 & 12.00 & 10.72 & 9.97 & 17.72 & 13.79 & 17.60 & 15.65 \\
\hline
\end{tabular}

\section{Discussion}

Table 8 provides a summary of the global RMS errors for the eight primary constituents, as well as the mean regional errors summed over these constituents, for each of the nine model simulations done as part of this study (statistics computed using only the 367 common validation data points).

Table 8. Summary of RMS errors (cm) for the 367 common validation stations: global means for the eight primary constituents and regional means summed over all eight primary harmonic constituents.

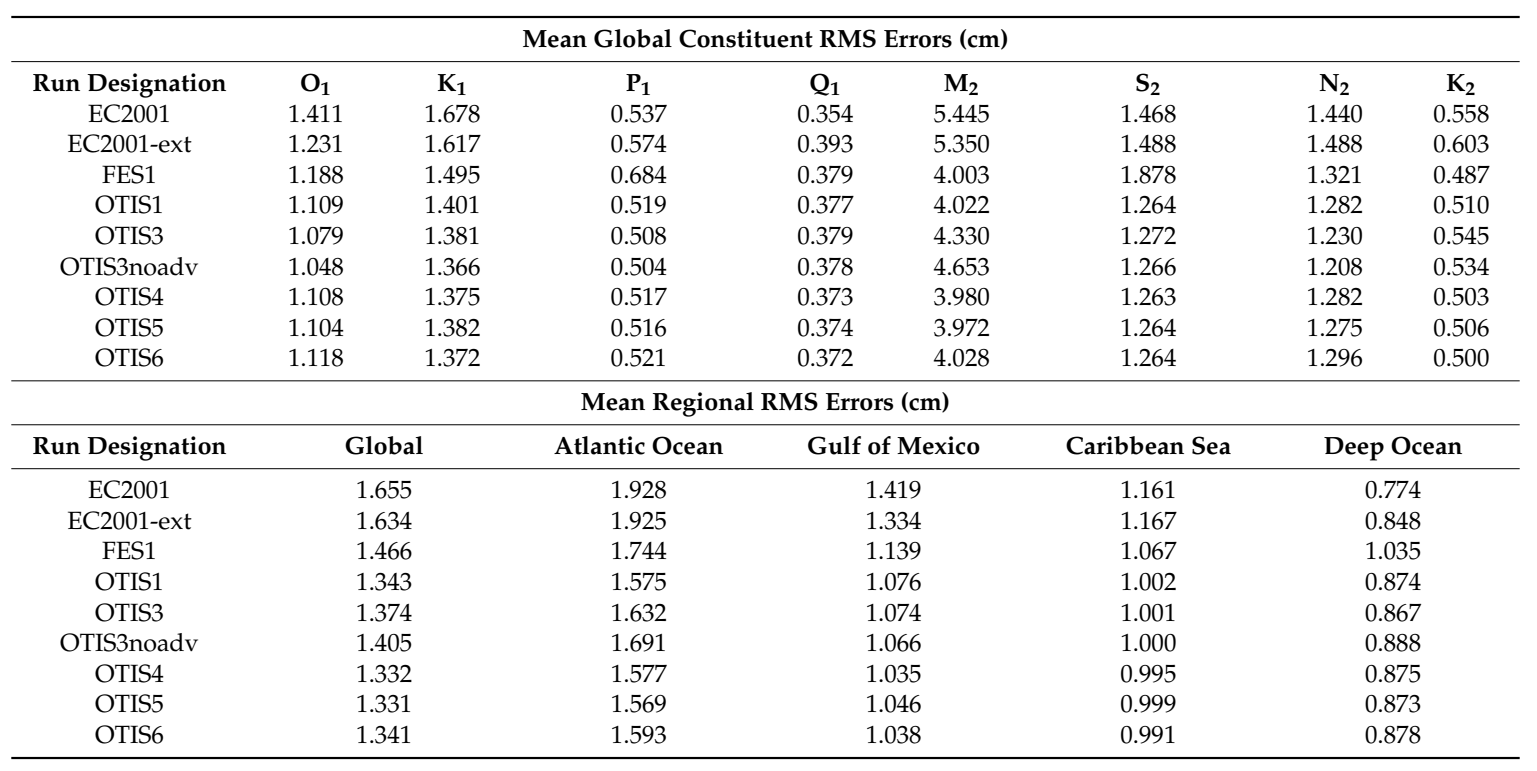

Notice that the placement of the boundary did not significantly change either the individual constituents (greatest change was a less than $0.2 \mathrm{~cm}$ reduction for $\mathrm{O}_{1}$ ) or the regional means, where the 
greatest difference was less than $0.1 \mathrm{~cm}$. Recall from Section 2.2.1 that this improvement was included primarily to increase the model stability for the long-term simulations of 410 days that were necessary for this study. While the slight model improvement is appreciated, it was not expected or required.

Meanwhile, the inclusion of the advective terms did not significantly affect the mean errors either. The largest difference was in the $\mathrm{M}_{2}$ constituent, which exhibited $0.3 \mathrm{~cm}$ reductions of error when the advective terms were included in the simulation, and the largest regional change was for the Atlantic stations (less than $0.05 \mathrm{~cm}$ difference). While these are not significant error reductions, it is important to include as much of the model physics as possible. Furthermore, examination of scatter plots for individual stations shows that the inclusion of the advective terms can have significant influence on certain types of stations (rivers, channels, shallower estuaries, etc.) where we would expect the hydrodynamics to be more dominated by advection.

Turning now to the open ocean boundary forcing, we note that the simulation with TPXO 7.2 forcing is on average more accurate than the FES2012 forcing. The most significant difference is for the $\mathrm{S}_{2}$ constituent, which exhibits $0.6 \mathrm{~cm}$ less error when the TPXO 7.2 product is used as the boundary condition, with the only other noticeable improvement being in the $\mathrm{P}_{1}$ constituent (about $0.15 \mathrm{~cm}$ ). Regionally, the reductions are about $0.15 \mathrm{~cm}$ for the deep and Atlantic stations. Interestingly, neither of these constituents has the highest phase or amplitude errors in Table 2. Visual examination of $\mathrm{P}_{1}$ amplitudes and phases along the open boundary indicate that the FES2012 product has a considerable phase lag, compared to TPXO 7.2, for this constituent along the entire length and a noticeable departure for the amplitudes near the coast of Nova Scotia. However, there are no significant differences visible for the $\mathrm{S}_{2}$ constituent. From this we infer that the non-linear interactions between the tides can indeed be very complex. Additionally, this highlights the need for accurate boundary conditions at any modeling level.

Finally, comparison of the various bottom friction schemes indicates that the bottom friction does not noticeably affect the overall statistical errors; there are very few differences across the OTIS1, OTIS3 and OTIS4 through OTIS6 simulations for constituents or regions. The exception to this is that the OTIS3 simulation is about $0.3 \mathrm{~cm}$ higher than all of the others for the $\mathrm{M}_{2}$ constituent, with most of these errors occurring (on average) in the Atlantic region. However, as shown in Appendix B, individual stations can be significantly affected when the bottom friction is varied, from which we infer that overall statistical improvement could be gained by optimizing the friction scheme in each coastal embayment and estuary.

\section{Conclusions}

The results indicate that most of the reduction in harmonic constituent errors are due to the increased coastal resolution and updated coastal bathymetry. On average, very little overall improvement was realized solely from the bottom friction representation, inclusion of advective terms or new open ocean boundary location. However, these do contribute to the overall stability and robustness of the model, as well as having localized effects on the harmonic accuracy.

To put the errors in context, we also computed the mean RMS error (for all eight primary constituents) between the CO-OPS station data and the IHO data for the 63 stations that were available in both data sets. The mean error for all 63 stations was $0.72 \mathrm{~cm}$, while the minimum and maximum error over all stations were $0.19 \mathrm{~cm}$ and $2.94 \mathrm{~cm}$, respectively. On average, one could expect the data itself to be in error by about $0.7 \mathrm{~cm}$ at a given station, which is about half of the global RMS errors reported in Table 8. The measured to computed error measures reported throughout the paper include these errors in the data; thus, a significant portion of the reported errors stem from the uncertainty in the data itself.

Future improvements to the WNAT tidal database could include better bottom friction representations in individual water bodies that have not been optimized (e.g., the upper reaches of Chesapeake Bay, marshy areas along the Florida coast and other regions indicated by the figures 
in Appendix C) and updated bathymetry for inlets and other important conveyances (e.g., Pamlico Sound inlets) as the VDatum models themselves are updated with more recent sounding data.

It is recommended that users of the EC2015 tidal database follow two basic guidelines: (1) choose your regional open ocean boundary location to be well outside of estuaries and bays and (2) make sure that your regional model bathymetry matches the database bathymetry at your boundary. Additionally, while harmonic information is available for 37 constituents, use caution when applying larger suites as only eight have been validated. Further guidelines and limitations are provided in Appendix D for the interested reader. The EC2015 tidal database is available on the ADCIRC website [24].

Acknowledgments: Funding for the project was provided by the National Oceanic and Atmospheric Administration. Additional resources were provided by the University of Oklahoma. The computing for this project was performed at the OU Supercomputing Center for Education \& Research (OSCER) at the University of Oklahoma (OU). Any opinions, conclusions, or findings are those of the authors and are not necessarily endorsed by the funding agencies. We also thank the reviewers for their insightful and constructive comments during the review process.

Author Contributions: R.K, K.D. and J.F. conceived the project and decided upon the six areas of improvement; J.W. created and validated the new EC2001_extended model domain and provided VDatum model grids and the most recent approved CO-OPS tidal constituent data; C.S. created the new EC2015 model domain, performed all of the ADCIRC model simulations to test the various improvements and analyzed the model results; K.D. modified the ADCIRC source code to allow internal harmonic analysis for large grids and the full suite of 37 constituents; C.S. wrote the paper.

Conflicts of Interest: The authors declare no conflict of interest. J.F. as a representative of the funding sponsor, was involved in designing the study. The funding sponsors had no role in the analyses or interpretation of data; in the writing of the manuscript, or in the decision to publish the results.

\section{Appendix A}

The locations, names and regional classification of all 681 validation stations are given herein; the last 277 stations are marked with IHO in the CO-OPS ID column to indicate that they are from the IHO bank of tidal constituents. Stations marked with a single asterisk are considered "wet" in the EC2001 model even though they are approximated by their nearest neighbor. Meanwhile, those marked with a double asterisk are not included in scatter plots or statistical error metrics for the EC2001 database since they are well outside the domain of the boundary or are in channels and other features that are not represented in the EC2001 model. Abbreviations for the region designations are as follows: Atlantic Ocean-A, Gulf of Mexico-G, Caribbean Sea-C, Deep water-D. 
Table A1. Geographic location, name and regional classification for available validation stations.

\begin{tabular}{|c|c|c|c|c|c|}
\hline ID & CO-OPS & Longitude & Latitude & Station Name & Region \\
\hline 1 & 2695540 & -64.70331 & 32.37339 & Bermuda Esso Pier, St. Georges Island & A \\
\hline 2 & 8410140 & -66.98290 & 44.90460 & Eastport, Passamaquoddy Bay & $\mathrm{A}$ \\
\hline $3^{* *}$ & 8410714 & -67.10840 & 44.87045 & Coffin Point, Coffin Neck & A \\
\hline $4^{* *}$ & 8410715 & -67.13000 & 44.92330 & Garnet Point, Hersey Neck & A \\
\hline $5^{* *}$ & 8410834 & -67.14375 & 45.12889 & Pettegrove Point, Dochet Island & A \\
\hline $6^{* *}$ & 8410864 & -67.15167 & 44.82333 & Gravelly Pt., Whiting Bay & $\mathrm{A}$ \\
\hline 7 & 8411060 & -67.20917 & 44.65637 & Cutler Farris Wharf, Little River & $\mathrm{A}$ \\
\hline 8 & 8411250 & -67.29670 & 44.64170 & Cutler Naval Base, Machias Bay & A \\
\hline $9^{* *}$ & 8412581 & -67.87500 & 44.54000 & Milbridge, Narraguagus River & A \\
\hline $10 * *$ & 8413320 & -68.20500 & 44.39170 & Bar Harbor, Frenchman Bay & $\mathrm{A}$ \\
\hline 11 & 8413825 & -68.43500 & 44.17000 & Mackerel Cove, Swans Island & A \\
\hline 12 & 8414249 & -68.62093 & 44.19231 & Oceanville, Deer Island & $\mathrm{A}$ \\
\hline $13^{* *}$ & 8414612 & -68.77190 & 44.78765 & Bangor, Penobscot River & A \\
\hline 14 & 8414721 & -68.81330 & 44.47170 & Fort Point, Penobscot River & $\mathrm{A}$ \\
\hline 15 & 8414888 & -68.88840 & 44.16080 & Pulpit Harbor, Penobscot Bay & $\mathrm{A}$ \\
\hline $16^{* *}$ & 8415490 & -69.10170 & 44.10500 & Rockland & A \\
\hline 17 ** & 8415709 & -69.18170 & 44.07136 & Thomaston, St George River & $\mathrm{A}$ \\
\hline 18 & 8417177 & -69.78500 & 43.75500 & Hunniwell Point, Kennebec River & A \\
\hline $19^{* *}$ & 8417208 & -69.79708 & 44.08721 & Richmond, Kennebec River & A \\
\hline 20 ** & 8417227 & -69.80880 & 43.92500 & Bath, Kennebec River & A \\
\hline $21 * *$ & 8418150 & -70.24601 & 43.65608 & Portland, Casco Bay & $\mathrm{A}$ \\
\hline $22 *$ & 8418445 & -70.33330 & 43.54000 & Pine Point, Scarborough River & $\mathrm{A}$ \\
\hline $23 *$ & 8418606 & -70.38170 & 43.46170 & Camp Ellis, Saco River & A \\
\hline $24 *$ & 8419317 & -70.56303 & 43.31966 & Wells, Webhannet River & A \\
\hline $25^{* *}$ & 8419870 & -70.74170 & 43.08000 & Seavey Island, Portsmouth Harbor & $\mathrm{A}$ \\
\hline $26^{* *}$ & 8423898 & -70.71167 & 43.07179 & Fort Point, Newcastle Island & A \\
\hline $27^{* *}$ & 8440273 & -70.90800 & 42.83600 & Salisbury Point, Merrimack River & A \\
\hline $28 *$ & 8440452 & -70.82000 & 42.81670 & Plum Island, Merrimack River Ent. & A \\
\hline 29 ** & 8440466 & -70.87330 & 42.81500 & Newburyport, Merrimack River & $\mathrm{A}$ \\
\hline $30 *$ & 8441551 & -70.61507 & 42.66033 & Rockport Harbor & $\mathrm{A}$ \\
\hline $31 * *$ & 8442645 & -70.87649 & 42.52295 & Salem, Salem Harbor & A \\
\hline $32 * *$ & 8443187 & -70.94330 & 42.45830 & Lynn, Lynn Harbor & $\mathrm{A}$ \\
\hline 33 ** & 8443970 & -71.04720 & 42.35750 & Boston, Boston Harbor & A \\
\hline 34 & 8444162 & -70.89170 & 42.32830 & Boston Light, Boston Harbor & $\mathrm{A}$ \\
\hline $35^{* *}$ & 8444525 & -70.95330 & 42.28000 & Nut Island, Quincy Bay & A \\
\hline 36 ** & 8444788 & -70.96670 & 42.24830 & Shipyard Point, Weymouth Fore River & A \\
\hline 37 & 8445138 & -70.72476 & 42.20099 & Scituate, Scituate Harbor & A \\
\hline 38 & 8446009 & -70.63873 & 42.08330 & Brant Rock, Green Harbor River & $\mathrm{A}$ \\
\hline 39 ** & 8446121 & -70.18216 & 42.04959 & Provincetown, Cape Cod & A \\
\hline $40 * *$ & 8446166 & -70.66789 & 42.03830 & Duxbury, Duxbury Harbor & A \\
\hline $41 *$ & 8446493 & -70.66170 & 41.96000 & Plymouth, Plymouth Harbor & $\mathrm{A}$ \\
\hline $42 * *$ & 8447173 & -70.53500 & 41.77500 & Sagamore, Cape Cod Canal & A \\
\hline $43^{* *}$ & 8447191 & -70.56170 & 41.77000 & Bournedale, Cape Cod Canal & $\mathrm{A}$ \\
\hline $44 *$ & 8447241 & -70.15550 & 41.75600 & Sesuit Harbor, East Dennis & $\mathrm{A}$ \\
\hline $45^{* *}$ & 8447259 & -70.59342 & 41.74585 & Bourne Bridge, Cape Cod Canal & $\mathrm{A}$ \\
\hline $46^{* *}$ & 8447270 & -70.61670 & 41.74170 & Buzzards Bay, Cape Cod Canal & A \\
\hline $47^{* *}$ & 8447295 & -70.62425 & 41.73500 & Gray Gables, Buzzards Bay & $\mathrm{A}$ \\
\hline 48 & 8447368 & -70.71500 & 41.71170 & Great Hill & A \\
\hline $49^{* *}$ & 8447386 & -71.16550 & 41.70580 & Fall River, Hope Bay & $\mathrm{A}$ \\
\hline 50 & 8447416 & -70.71941 & 41.69578 & Piney Point, Wings Cove & A \\
\hline $51 *$ & 8447435 & -69.94887 & 41.68847 & Chatham, Lydia Cove & $\mathrm{A}$ \\
\hline 52 & 8447495 & -70.05670 & 41.66478 & Saquatucket Harbor & $\mathrm{A}$ \\
\hline 53 & 8447712 & -70.89981 & 41.59292 & New Bedford, Clarks Point & $\mathrm{A}$ \\
\hline 54 & 8447842 & -70.92830 & 41.53830 & Round Hill Point & $\mathrm{A}$ \\
\hline 55 & 8447930 & -70.67170 & 41.52330 & Woods Hole, Buzzards Bay & $\mathrm{A}$ \\
\hline $56^{* *}$ & 8448157 & -70.59870 & 41.45830 & Vineyard Haven, Vineyard Hvn $\mathrm{Hbr}$ & A \\
\hline $57 * *$ & 8448558 & -70.51150 & 41.38822 & Edgartown, Martha's Vineyard & A \\
\hline
\end{tabular}


Table A1. Cont.

\begin{tabular}{|c|c|c|c|c|c|}
\hline ID & CO-OPS & Longitude & Latitude & Station Name & Region \\
\hline $58 *$ & 8448725 & -70.76795 & 41.35461 & Menemsha Harbor & $\mathrm{A}$ \\
\hline $59 * *$ & 8449130 & -70.09438 & 41.28503 & Nantucket Island, Nantucket Sound & A \\
\hline $60 *$ & 8451552 & -71.25500 & 41.63670 & Bristol Ferry & A \\
\hline 61 & 8452660 & -71.32670 & 41.50500 & Newport, Narragansett Bay & $\mathrm{A}$ \\
\hline 62 & 8452944 & -71.34330 & 41.71670 & Conimicut Light, Narragansett Bay & $\mathrm{A}$ \\
\hline 63 & 8453742 & -71.38670 & 41.49670 & West Jamestown & $\mathrm{A}$ \\
\hline $64^{* *}$ & 8454000 & -71.39978 & 41.80786 & Providence, Providence River & $\mathrm{A}$ \\
\hline $65 *$ & 8454049 & -71.41100 & 41.58680 & Quonset Point & $\mathrm{A}$ \\
\hline $66^{* *}$ & 8454538 & -71.44346 & 41.57384 & Wickford, Narragansett Bay & $\mathrm{A}$ \\
\hline 67 & 8455083 & -71.49000 & 41.36330 & Point Judith, Harbor Of Refuge & A \\
\hline 68 & 8458022 & -71.76170 & 41.32830 & Weekapaug Point, Block Island Sound & A \\
\hline 69 & 8459338 & -71.55621 & 41.17404 & Block Island Harbor, Old Harbor & $\mathrm{A}$ \\
\hline 70 & 8459479 & -71.58000 & 41.22830 & Sandy Point, Block Island Sound & $\mathrm{A}$ \\
\hline 71 & 8459681 & -71.61064 & 41.16330 & Block Island, Block Island Sound & $\mathrm{A}$ \\
\hline $72 * *$ & 8461490 & -72.08975 & 41.36105 & New London, Thames River & $\mathrm{A}$ \\
\hline $73 * *$ & 8463701 & -72.53170 & 41.26830 & Clinton, Clinton Harbor & $\mathrm{A}$ \\
\hline $74^{* *}$ & 8465705 & -72.90830 & 41.28330 & New Haven, New Haven Harbor & $\mathrm{A}$ \\
\hline $75^{* *}$ & 8467150 & -73.18170 & 41.17330 & Bridgeport, Bridgeport Harbor & A \\
\hline $76 *$ & 8467373 & -73.21330 & 41.15670 & Black Rock Harbor, Cedar Creek & $\mathrm{A}$ \\
\hline $77^{* *}$ & 8467726 & -73.28286 & 41.13249 & Southport, Southport Harbor & A \\
\hline 78 & 8468799 & -73.48000 & 41.03830 & Long Neck Point, Long Island Sound & $\mathrm{A}$ \\
\hline 79 & 8510321 & -71.85586 & 41.07199 & Montauk Point Light & $\mathrm{A}$ \\
\hline $80 *$ & 8510448 & -71.93500 & 41.07330 & Lake Montauk (U.S.C.G.) & A \\
\hline $81^{* *}$ & 8510560 & -71.96000 & 41.04830 & Montauk, Fort Pond Bay & A \\
\hline 82 & 8510719 & -72.03191 & 41.25792 & Silver Eel Pond, Fishers Island & $\mathrm{A}$ \\
\hline $83^{*}$ & 8511171 & -72.19000 & 41.03500 & Threemile Harbor Entrance & $\mathrm{A}$ \\
\hline 84 & 8511236 & -72.20521 & 41.17125 & Plum Island Plum Gut Harbor & A \\
\hline 85 & 8511671 & -72.30670 & 41.13670 & Orient, Orient Harbor & $\mathrm{A}$ \\
\hline 86 & 8512668 & -72.56170 & 41.01500 & Mattituck Inlet, Long Island & A \\
\hline $87^{* *}$ & 8512735 & -72.58170 & 40.93470 & South Jamesport, Great Peconic & $\mathrm{A}$ \\
\hline $88^{* *}$ & 8512769 & -72.58667 & 40.81830 & Shinnecock Yacht Club, Penn. Creek & $\mathrm{A}$ \\
\hline $89 *$ & 8512987 & -72.64500 & 40.98170 & Northville Fuel Dock, Long Island & $\mathrm{A}$ \\
\hline 90 & 8513825 & -72.86830 & 40.73830 & Smith Point Bridge, Narrow Bay & $\mathrm{A}$ \\
\hline $91 *$ & 8514322 & -73.00000 & 40.74780 & Patchogue, Patchogue River & $\mathrm{A}$ \\
\hline $92 *$ & 8514422 & -73.04330 & 40.96500 & Cedar Beach & A \\
\hline $93^{* *}$ & 8515586 & -73.35330 & 40.90000 & Northport, Northport Bay & A \\
\hline 94 & 8515786 & -73.40000 & 40.95330 & Eatons Neck, Huntington Bay & $\mathrm{A}$ \\
\hline $95^{* *}$ & 8515921 & -73.43170 & 40.91000 & Lloyd Harbor Lighthouse & $\mathrm{A}$ \\
\hline $96^{* *}$ & 8516061 & -73.47000 & 40.87330 & Cold Springs Harbor & $\mathrm{A}$ \\
\hline $97^{* *}$ & 8516299 & -73.55000 & 40.90330 & Bayville Bridge, Oyster Bay & A \\
\hline $98^{* *}$ & 8516614 & -73.65500 & 40.86330 & Glen Cove Yacht Club, Long Island & $\mathrm{A}$ \\
\hline $99^{* *}$ & 8516761 & -73.70330 & 40.83170 & Port Washington, Manhassset Bay & A \\
\hline $100 *$ & 8516945 & -73.76490 & 40.81030 & Kings Point, Long Island Sound & $\mathrm{A}$ \\
\hline $101^{* *}$ & 8516990 & -73.78170 & 40.79330 & Willets Point, Little Bay, East River & $\mathrm{A}$ \\
\hline $102 * *$ & 8517276 & -73.85670 & 40.78330 & College Pt, Ft. Of 110Th St & $\mathrm{A}$ \\
\hline $103^{* *}$ & 8517847 & -73.99517 & 40.70374 & Brooklyn Bridge, East River & A \\
\hline 104 & 8518091 & -73.67170 & 40.96170 & Rye Beach, Amusement Park & A \\
\hline $105^{* *}$ & 8518639 & -73.90625 & 40.80133 & Port Morris, East 138Th St. & $\mathrm{A}$ \\
\hline $106^{* *}$ & 8518668 & -73.94170 & 40.77670 & Horns Hook, E. 90Th St. Hell Gate & $\mathrm{A}$ \\
\hline $107 * *$ & 8518687 & -73.95830 & 40.75830 & Queensboro Bridge, East River & $\mathrm{A}$ \\
\hline $108^{* *}$ & 8518699 & -73.96956 & 40.71170 & Williamsburg Bridge & $\mathrm{A}$ \\
\hline $109 * *$ & 8518750 & -74.01436 & 40.70020 & The Battery, New York Harbor & $\mathrm{A}$ \\
\hline $110^{* *}$ & 8518903 & -73.92500 & 40.87830 & Spuyten Duyvil Ck, Ent., Hudson R. & $\mathrm{A}$ \\
\hline $111^{* *}$ & 8518905 & -73.91670 & 40.90330 & Riverdale, Hudson River & A \\
\hline $112 * *$ & 8518924 & -73.96330 & 41.21830 & Haverstraw Bay & $\mathrm{A}$ \\
\hline $113^{* *}$ & 8519483 & -74.14230 & 40.63980 & Bergen Point West, Kill Van Kull & A \\
\hline
\end{tabular}


Table A1. Cont.

\begin{tabular}{|c|c|c|c|c|c|}
\hline ID & CO-OPS & Longitude & Latitude & Station Name & Region \\
\hline $114 *$ & 8531680 & -74.00940 & 40.46690 & Sandy Hook & $\mathrm{A}$ \\
\hline 115 & 8534720 & -74.41830 & 39.35500 & Atlantic City, Atlantic Ocean & A \\
\hline 116 & 8534770 & -74.47670 & 39.33500 & Ventnor City, Fishing Pier & A \\
\hline $117 *$ & 8534836 & -74.53330 & 39.30830 & Longport, Risely Channel & $\mathrm{A}$ \\
\hline $118^{*}$ & 8536110 & -74.96000 & 38.96833 & Cape May Canal, Delaware Bay & A \\
\hline $119 *$ & 8536581 & -74.89170 & 39.12830 & Bidwell Creek Entrance, Del. Bay & A \\
\hline $120 *$ & 8536931 & -75.17500 & 39.23830 & Fortescue Creek & $\mathrm{A}$ \\
\hline 121 & 8537121 & -75.37500 & 39.30500 & Ship John Shoal, Delaware River & $\mathrm{A}$ \\
\hline $122 * *$ & 8538886 & -75.04300 & 40.01194 & Tacony-Palmyra Bridge & A \\
\hline $123^{* *}$ & 8539094 & -74.86970 & 40.08170 & Burlington, Delaware River & A \\
\hline $124 * *$ & 8539487 & -74.73670 & 40.13670 & Fieldsboro, Delaware River & A \\
\hline $125^{* *}$ & 8539993 & -74.75500 & 40.18830 & Trenton Marine Terminal & A \\
\hline $126^{* *}$ & 8540433 & -75.41000 & 39.81170 & Marcus Hook & A \\
\hline $127^{* *}$ & 8545240 & -75.14091 & 39.93333 & Philadelphia (U.S.C.G.), Del. River & $\mathrm{A}$ \\
\hline $128^{* *}$ & 8545530 & -75.13830 & 39.95330 & Philadelphia (Pier 11 North), Del. R & A \\
\hline $129 * *$ & 8548989 & -74.75170 & 40.13670 & Newbold, Delaware River & $\mathrm{A}$ \\
\hline $130 * *$ & 8551762 & -75.58830 & 39.58170 & Delaware City, Delaware River & $\mathrm{A}$ \\
\hline $131^{* *}$ & 8551910 & -75.57331 & 39.55870 & Reedy Point, C\&D Canal & A \\
\hline $132 *$ & 8554399 & -75.40000 & 39.18500 & Mahon River Entrance, Del. Bay & $\mathrm{A}$ \\
\hline 133 & 8555889 & -75.11333 & 38.98667 & Brandywine Shoal Light, Del. Bay & $\mathrm{A}$ \\
\hline $134 *$ & 8557380 & -75.12000 & 38.78200 & Lewes, Ft. Miles & A \\
\hline $135 *$ & 8558690 & -75.07000 & 38.61000 & Indian River Inlet & A \\
\hline 136 & 8570280 & -75.08330 & 38.32670 & Ocean City, Fishing Pier & A \\
\hline $137 * *$ & 8570283 & -75.09167 & 38.32833 & Ocean City Inlet & $\mathrm{A}$ \\
\hline $138^{* *}$ & 8570536 & -75.18909 & 38.21516 & South Point, Chincoteague Bay & $\mathrm{A}$ \\
\hline $139 * *$ & 8570649 & -75.28500 & 38.14830 & Public Landing, Chincoteague Bay & $\mathrm{A}$ \\
\hline $140 * *$ & 8571091 & -75.86330 & 37.97670 & Crisfield & A \\
\hline 141 & 8571117 & -76.02895 & 37.99826 & Ewell, Smith Island & A \\
\hline 142 & 8571421 & -76.03830 & 38.22000 & Bishops Head, Hoopers Strait & A \\
\hline $143^{* *}$ & 8571559 & -76.00500 & 38.30000 & Mccreadys Creek, Fishing Bay & $\mathrm{A}$ \\
\hline $144^{*}$ & 8571579 & -76.26500 & 38.34170 & Barren Island, Chesapeake Bay & $\mathrm{A}$ \\
\hline $145 * *$ & 8571773 & -75.81930 & 38.48396 & Vienna, Nanicoke River & $\mathrm{A}$ \\
\hline $146^{* *}$ & 8571892 & -76.06818 & 38.57354 & Cambridge, Choptank River & A \\
\hline $147^{*}$ & 8572467 & -76.37330 & 38.83670 & Kent Point, Chesapeake Bay & $\mathrm{A}$ \\
\hline $148^{* *}$ & 8572669 & -75.94500 & 38.91670 & Hillsboro, Tuckahoe Creek & A \\
\hline $149 *$ & 8572770 & -76.35500 & 38.95670 & Matapeake & A \\
\hline 150 & 8572955 & -76.30110 & 39.03170 & Love Point Pier, Kent Island & A \\
\hline $151^{* *}$ & 8573349 & -75.92500 & 39.24500 & Crumpton, Chester River & A \\
\hline $152 *$ & 8573364 & -76.24577 & 39.21333 & Tolchester Beach, Chesapeake Bay & A \\
\hline $153 *$ & 8573704 & -76.06330 & 39.37170 & Betterton, Sassafras River & A \\
\hline $154^{* *}$ & 8573903 & -75.91670 & 39.50330 & Town Point Wharf & A \\
\hline $155^{* *}$ & 8573927 & -75.81000 & 39.52766 & Chesapeake City & $\mathrm{A}$ \\
\hline $156^{*}$ & 8574070 & -76.09000 & 39.53670 & Havre De Grace, Chesapeake Bay & A \\
\hline $157^{* *}$ & 8574459 & -76.25500 & 39.38830 & Pond Point, Bush River & $\mathrm{A}$ \\
\hline $158^{* *}$ & 8574680 & -76.57833 & 39.26667 & Baltimore (Fort McHenry) & A \\
\hline $159^{* *}$ & 8574683 & -76.58500 & 39.26170 & Fort McHenry Marsh, Patapsco R & A \\
\hline 160 ** & 8575512 & -76.48099 & 38.98441 & U.S. Naval Academy, Severn River & A \\
\hline 161 & 8577004 & -76.47261 & 38.46579 & Long Beach, Chesapeake Bay & A \\
\hline $162 *$ & 8577188 & -76.39640 & 38.39340 & Cove Point & $\mathrm{A}$ \\
\hline $163^{* *}$ & 8577330 & -76.45167 & 38.31667 & Solomons Island, Patuxent River & A \\
\hline $164^{* *}$ & 8579542 & -76.68333 & 38.65500 & Lower Marlboro, Patuxent River & A \\
\hline $165^{* *}$ & 8579997 & -76.93923 & 38.93240 & Bladensburg, Anacostia River & A \\
\hline $166^{* *}$ & 8594900 & -77.02167 & 38.87333 & Washington, Potomac River & $\mathrm{A}$ \\
\hline $167 * *$ & 8630308 & -75.40516 & 37.90701 & Chincoteague Channel, South End & A \\
\hline 168 & 8632200 & -75.98844 & 37.16519 & Kiptopeke, Chesapeake Bay & A \\
\hline $169 *$ & 8632366 & -76.02450 & 37.26330 & Cape Charles Harbor (U.S.C.G.) & A \\
\hline 170 & 8632837 & -76.01500 & 37.53830 & Rappahannock Light & $\mathrm{A}$ \\
\hline
\end{tabular}


Table A1. Cont.

\begin{tabular}{|c|c|c|c|c|c|}
\hline ID & CO-OPS & Longitude & Latitude & Station Name & Region \\
\hline $171^{* *}$ & 8632869 & -75.91670 & 37.55670 & Gaskins Pt., Occohannock Creek & A \\
\hline 172 & 8633532 & -75.99288 & 37.82926 & Tangier Island, Chesapeake Bay & A \\
\hline 173 & 8635150 & -76.96000 & 38.25170 & Colonial Beach, Potomac River & A \\
\hline $174^{* *}$ & 8635257 & -77.24297 & 38.21330 & Rappahannock Bend & $\mathrm{A}$ \\
\hline $175^{* *}$ & 8635750 & -76.46444 & 37.99590 & Lewisetta, Potomac River & A \\
\hline $176^{* *}$ & 8635985 & -76.78330 & 37.87330 & Wares Wharf, Rappahannock R & $\mathrm{A}$ \\
\hline $177 *$ & 8636580 & -76.29000 & 37.61442 & Windmill Point, Rappahannock R & $\mathrm{A}$ \\
\hline $178^{* *}$ & 8636653 & -76.98996 & 37.58327 & Lester Manor & $\mathrm{A}$ \\
\hline $179 *$ & 8637289 & -76.27330 & 37.34670 & New Point & $\mathrm{A}$ \\
\hline 180 & 8637590 & -76.22170 & 37.25670 & New Point, Comfort Shoal & A \\
\hline $181^{* *}$ & 8637624 & -76.50000 & 37.24670 & Gloucester Point, York River & $\mathrm{A}$ \\
\hline $182 * *$ & 8637689 & -76.47833 & 37.22667 & Yorktown U.S.C.G. Training Center & A \\
\hline $183^{* *}$ & 8638339 & -76.39911 & 36.82322 & Western Branch & $\mathrm{A}$ \\
\hline $184^{* *}$ & 8638421 & -76.66830 & 37.05670 & Burwell Bay, James River & $\mathrm{A}$ \\
\hline $185 * *$ & 8638424 & -76.66330 & 37.22000 & Kingsmill, James River & A \\
\hline $186^{* *}$ & 8638433 & -76.78330 & 37.18500 & Scotland, James River & $\mathrm{A}$ \\
\hline $187^{* *}$ & 8638445 & -76.91170 & 37.40330 & Lanexa, Chicahominy River & A \\
\hline $188^{* *}$ & 8638450 & -76.94330 & 37.23988 & Tettington, James River & A \\
\hline $189 * *$ & 8638489 & -77.37338 & 37.26686 & Puddledock, Appomattox River & $\mathrm{A}$ \\
\hline $190 * *$ & 8638495 & -77.42060 & 37.52451 & Richmond River Locks, James River & $\mathrm{A}$ \\
\hline $191 *$ & 8638610 & -76.33000 & 36.94667 & Sewells Point, Hampton Roads & $\mathrm{A}$ \\
\hline $192 * *$ & 8638660 & -76.29202 & 36.82168 & Norfolk Naval Shipyard & A \\
\hline 193 & 8638863 & -76.11333 & 36.96667 & Chesapeake Bay Bridge Tunnel & A \\
\hline 194 & 8639207 & -75.96984 & 36.83180 & Inside Channel, Rudee Inlet & $\mathrm{A}$ \\
\hline $195^{* *}$ & 8639348 & -76.30172 & 36.77804 & Money Point, S. Br. Elizabeth River & $\mathrm{A}$ \\
\hline 196 & 8651370 & -75.74669 & 36.18331 & Duck, Frf Pier & A \\
\hline $197^{* *}$ & 8652247 & -75.76890 & 35.90370 & Manns Harbor, Croatan Sound & A \\
\hline $198^{* *}$ & 8652437 & -75.65645 & 35.84482 & Oyster Creek, Croatan Sound & $\mathrm{A}$ \\
\hline $199 * *$ & 8652547 & -75.70000 & 35.81170 & Roanoke Marshes Light, Croatan S & A \\
\hline $200 * *$ & 8652587 & -75.54936 & 35.79429 & Oregon Inlet Marina, Pamlico S & $\mathrm{A}$ \\
\hline 201 & 8654400 & -75.63500 & 35.22330 & Cape Hatteras Fishing Pier & $\mathrm{A}$ \\
\hline $202 * *$ & 8654467 & -75.70417 & 35.20950 & U.S.C.G. Hatteras, Pamlico S & $\mathrm{A}$ \\
\hline $203^{* *}$ & 8654792 & -75.98945 & 35.11564 & Ocracoke Island & A \\
\hline $204^{* *}$ & 8655875 & -76.34330 & 34.87500 & Sea Level, Core Sound & $\mathrm{A}$ \\
\hline $205^{* *}$ & 8656483 & -76.67000 & 34.72000 & Beaufort, Duke Marine Lab & A \\
\hline 206 & 8656590 & -76.71170 & 34.69330 & Atlantic Beach Triple S Pier & A \\
\hline $207^{* *}$ & 8658120 & -77.95330 & 34.22670 & Wilmington, Cape Fear River & A \\
\hline 208 & 8658163 & -77.78566 & 34.21330 & Wrightsville Beach & A \\
\hline $209 * *$ & 8659084 & -78.01830 & 33.91500 & Southport & A \\
\hline 210 & 8659182 & -78.08170 & 33.90170 & Oak Island, Atlantic Ocean & A \\
\hline $211 *$ & 8659897 & -78.50670 & 33.86500 & Sunset Beach Pier, Atlantic Ocean & A \\
\hline 212 & 8661070 & -78.91830 & 33.65500 & Springmaid Pier, Atlantic Ocean & A \\
\hline $213^{* *}$ & 8664022 & -79.92138 & 33.00880 & Gen. Dynamics Pier, Cooper R. & A \\
\hline $214^{* *}$ & 8664545 & -79.83000 & 32.92670 & Cainhoy, Wando River & $\mathrm{A}$ \\
\hline $215 * *$ & 8664941 & -79.70670 & 32.85670 & South Capers Island, Capers Creek & $\mathrm{A}$ \\
\hline $216^{* *}$ & 8665099 & -80.02170 & 32.83670 & I-526 Bridge, Ashley River & A \\
\hline $217^{* *}$ & 8665530 & -79.92378 & 32.78170 & Charleston, Cooper River Entrance & A \\
\hline $218^{* *}$ & 8667633 & -80.78410 & 32.50250 & Clarendon Plantation, Whale Br. & $\mathrm{A}$ \\
\hline $219 * *$ & 8668498 & -80.46500 & 32.34000 & Hunting Island Pier, Fripps Inlet & $\mathrm{A}$ \\
\hline 220 & 8668918 & -80.73670 & 32.26670 & Ribaut Island, Skull Creek & A \\
\hline $221^{* *}$ & 8670870 & -80.90170 & 32.03373 & Fort Pulaski, Savannah River & $\mathrm{A}$ \\
\hline $222 * *$ & 8677344 & -81.39670 & 31.13170 & St Simons Lighthouse & A \\
\hline $223 * *$ & 8679511 & -81.51323 & 30.79781 & Kings Bay & A \\
\hline $224^{* *}$ & 8679758 & -81.47170 & 30.76330 & Dungeness, Seacamp Dock & A \\
\hline $225 * *$ & 8679964 & -81.54830 & 30.72000 & St. Marys, St. Marys River & $\mathrm{A}$ \\
\hline $226^{* *}$ & 8720011 & -81.46500 & 30.70830 & Cut 1N, St Marys River Entr & A \\
\hline 227 & 8720012 & -81.30170 & 30.71670 & Cut 2N, St Marys River Entr & $\mathrm{A}$ \\
\hline
\end{tabular}


Table A1. Cont.

\begin{tabular}{|c|c|c|c|c|c|}
\hline ID & CO-OPS & Longitude & Latitude & Station Name & Region \\
\hline $228 * *$ & 8720030 & -81.46539 & 30.67171 & Fernandina Beach, Amelia River & A \\
\hline $229 * *$ & 8720051 & -81.52330 & 30.64330 & Lanceford Creek, Lofton & A \\
\hline $230 * *$ & 8720098 & -81.51500 & 30.56830 & Nassauville, Nassau River East & A \\
\hline $231^{* *}$ & 8720211 & -81.41330 & 30.40000 & Mayport (Naval Sta.) St Johns R & A \\
\hline $232 * *$ & 8720218 & -81.43000 & 30.39670 & Bar Pilots Dock, St Johns River & A \\
\hline $233 * *$ & 8720219 & -81.55830 & 30.38670 & Dames Point, St. Johns River & A \\
\hline $234^{* *}$ & 8720220 & -81.43170 & 30.39330 & Mayport (Ferry) Saint Johns R & $\mathrm{A}$ \\
\hline $235 * *$ & 8720225 & -81.63408 & 30.38337 & Phoenix Park & A \\
\hline $236^{* *}$ & 8720242 & -81.62000 & 30.36000 & Longbranch, St Johns River & A \\
\hline $237 *$ & 8720291 & -81.38670 & 30.28330 & Jacksonville Beach & A \\
\hline $238^{* *}$ & 8720357 & -81.69164 & 30.19170 & I-295 Bridge, West End, St Johns R & A \\
\hline $239 * *$ & 8720503 & -81.62830 & 29.97830 & Red Bay Point, St Johns River & $\mathrm{A}$ \\
\hline $240^{* *}$ & 8720554 & -81.30000 & 29.91670 & Vilano Beach (ICWW) & A \\
\hline $241 * *$ & 8720582 & -81.30670 & 29.86670 & State Road 312, Matanzas River & A \\
\hline 242 & 8720587 & -81.26330 & 29.85670 & St. Augustine Beach, Atlantic & A \\
\hline $243^{* *}$ & 8720625 & -81.54832 & 29.80165 & Racy Point, St Johns River & A \\
\hline $244^{* *}$ & 8720651 & -81.25830 & 29.76830 & Crescent Beach, Matanzas River & $\mathrm{A}$ \\
\hline $245^{* *}$ & 8720692 & -81.22786 & 29.70453 & State Road A1A Bridge & A \\
\hline $246^{* *}$ & 8720757 & -81.20500 & 29.61500 & Bings Landing, Matanzas River & A \\
\hline $247^{* *}$ & 8720767 & -81.68170 & 29.59500 & Buffalo Bluff, St. Johns River & A \\
\hline $248^{* *}$ & 8720774 & -81.63170 & 29.64328 & Palatka, St. Johns River & $\mathrm{A}$ \\
\hline $249 * *$ & 8720832 & -81.67520 & 29.47675 & Welaka, St. Johns River & A \\
\hline $250 *$ & 8721020 & -81.00500 & 29.22830 & Daytona Beach (Ocean) & $\mathrm{A}$ \\
\hline $251^{* *}$ & 8721604 & -80.59350 & 28.41580 & Trident Pier, Port Canaveral & A \\
\hline $252 * *$ & 8721608 & -80.60152 & 28.40871 & Canaveral Harbor Entrance & A \\
\hline $253^{* *}$ & 8722125 & -80.37170 & 27.63170 & Vero Beach, Indian River & $\mathrm{A}$ \\
\hline $254 * *$ & 8722208 & -80.32500 & 27.47170 & North Beach Causeway, Indian R & $\mathrm{A}$ \\
\hline $255^{* *}$ & 8722548 & -80.06670 & 26.84330 & Pga Boulevard Bridge, Palm Beach & A \\
\hline $256^{* *}$ & 8722588 & -80.05096 & 26.77000 & Port Of W. Palm Beach, Lake Worth & A \\
\hline $257^{* *}$ & 8722669 & -80.04670 & 26.61330 & Lake Worth (ICWW) & $\mathrm{A}$ \\
\hline 258 & 8722670 & -80.03330 & 26.61170 & Lake Worth Pier, Atlantic Ocean & A \\
\hline $259 *$ & 8723080 & -80.12000 & 25.90330 & Haulover Pier, N. Miami Beach & A \\
\hline 260 & 8723170 & -80.13154 & 25.76830 & Miami Beach (City Pier) & A \\
\hline 261 & 8723178 & -80.13000 & 25.76330 & Miami Beach, Government Cut & $\mathrm{A}$ \\
\hline 262 & 8723214 & -80.16180 & 25.73140 & Virginia Key, Biscayne Bay & A \\
\hline $263 *$ & 8723962 & -81.01670 & 24.71830 & Key Colony Beach & G \\
\hline $264 *$ & 8723970 & -81.10500 & 24.71170 & Vaca Key, Florida Bay & G \\
\hline $265 *$ & 8724580 & -81.80790 & 24.55570 & Key West & G \\
\hline 266 & 8724635 & -81.87830 & 24.45330 & Sand Key Lighthouse & G \\
\hline 267 & 8724671 & -81.92153 & 24.71828 & Smith Shoal Light, Fl & G \\
\hline 268 & 8724698 & -82.92000 & 24.63170 & Loggerhead Key, Dry Tortugas & G \\
\hline $269 *$ & 8725110 & -81.80750 & 26.13170 & Naples, Gulf Of Mexico & G \\
\hline $270 * *$ & 8725520 & -81.87120 & 26.64770 & Fort Myers, Caloosahatchee River & G \\
\hline 271 & 8726347 & -82.76000 & 27.60170 & Egmont Key, Tampa Bay & G \\
\hline 272 & 8726364 & -82.72670 & 27.61500 & Mullet Key, Tampa Bay & G \\
\hline 273 & 8726384 & -82.56210 & 27.63870 & Port Manatee, Tampa Bay & G \\
\hline 274 & 8726520 & -82.62690 & 27.76060 & St. Petersburg, Tampa Bay & G \\
\hline $275^{*}$ & 8726607 & -82.55376 & 27.85778 & Port Tampa, Old Tampa Bay & G \\
\hline $276^{* *}$ & 8726667 & -82.42500 & 27.91333 & Csx Rockport, Mckay Bay Entrance & G \\
\hline 277 & 8726724 & -82.83170 & 27.97830 & Clearwater Beach, Gulf Of Mexico & G \\
\hline $278^{* *}$ & 8726738 & -82.68500 & 27.98830 & Safety Harbor, Old Tampa Bay & G \\
\hline $279 * *$ & 8727235 & -82.63830 & 28.69170 & Johns Island, Chassahowitzka Bay & G \\
\hline $280^{* *}$ & 8727274 & -82.63830 & 28.76170 & Mason Creek, Homosassa Bay & G \\
\hline $281^{* *}$ & 8727277 & -82.69540 & 28.77170 & Tuckers Island, Homosassa River & G \\
\hline $282 * *$ & 8727293 & -82.60330 & 28.80063 & Halls River Bridge, Halls River & G \\
\hline $283^{* *}$ & 8727306 & -82.65830 & 28.82500 & Ozello & G \\
\hline $284^{* *}$ & 8727328 & -82.66670 & 28.86330 & Ozello North & G \\
\hline
\end{tabular}


Table A1. Cont.

\begin{tabular}{|c|c|c|c|c|c|}
\hline ID & CO-OPS & Longitude & Latitude & Station Name & Region \\
\hline 285 & 8727333 & -82.72330 & 28.87000 & Mangrove Point, Crystal Bay & G \\
\hline $286 * *$ & 8727336 & -82.63500 & 28.88170 & Dixie Bay & G \\
\hline $287^{* *}$ & 8727348 & -82.63829 & 28.90505 & Twin Rivers Marina, Crystal River & G \\
\hline $288^{* *}$ & 8727359 & -82.69170 & 28.92330 & Shell Island, Crystal River & G \\
\hline 289 & 8727520 & -83.03170 & 29.13500 & Cedar Key, Gulf Of Mexico & G \\
\hline $290 *$ & 8728229 & -84.29000 & 30.05870 & Shell Point, Walker Creek & G \\
\hline $291 *$ & 8728360 & -84.51170 & 29.91500 & Turkey Point & G \\
\hline $292 * *$ & 8728690 & -84.98138 & 29.72670 & Apalachicola, Apalachicola River & G \\
\hline $293 * *$ & 8729108 & -85.66694 & 30.15228 & Panama City, St. Andrew Bay & G \\
\hline 294 & 8729210 & -85.87830 & 30.21330 & Panama City Beach, Gulf Of Mexico & G \\
\hline $295^{* *}$ & 8729501 & -86.49330 & 30.50330 & Valpariso, Boggy Bayou & $\mathrm{G}$ \\
\hline 296 & 8729678 & -86.86500 & 30.37670 & Navarre Beach & G \\
\hline $297 * *$ & 8729905 & -87.35670 & 30.41860 & Millview, Perdido Bay & G \\
\hline $298^{* *}$ & 8729941 & -87.42881 & 30.38694 & Blue Angels Park, Perdido Bay & G \\
\hline $299 * *$ & 8731439 & -87.68428 & 30.27982 & Gulf Shores, Icww & G \\
\hline $300 *$ & 8733821 & -87.93453 & 30.48664 & Point Clear, Mobile Bay & G \\
\hline 301 & 8735180 & -88.07500 & 30.25000 & Dauphin Island, Mobile Bay & $\mathrm{G}$ \\
\hline $302 * *$ & 8735391 & -88.08800 & 30.56517 & SH 163 Bridge, Dog River & G \\
\hline $303 * *$ & 8737048 & -88.04010 & 30.70830 & Mobile State Docks, Mobile River & G \\
\hline 304 & 8741196 & -88.53330 & 30.34000 & Pascagoula Point, Miss. Sound & G \\
\hline $305 *$ & 8742221 & -88.66670 & 30.23830 & Horn Island, Mississippi Sound & G \\
\hline $306^{* *}$ & 8743281 & -88.79830 & 30.39170 & Ocean Springs & G \\
\hline $307^{* *}$ & 8744117 & -88.90330 & 30.41175 & Biloxi, Bay Of Biloxi & G \\
\hline 308 & 8745557 & -89.08170 & 30.36000 & Gulfport Harbor, Mississippi Sound & G \\
\hline 309 & 8747437 & -89.32578 & 30.32639 & Bay Waveland Yacht, Bay St. Louis & G \\
\hline 310 & 8747766 & -89.36670 & 30.28170 & Waveland, Mississippi Sound & G \\
\hline 311 & 8760417 & -89.04447 & 29.20075 & Devon Energy Facility, North Pass & G \\
\hline 312 & 8760551 & -89.14000 & 28.99000 & South Pass & $\mathrm{G}$ \\
\hline 313 & 8760721 & -89.25830 & 29.17830 & Pilottown & G \\
\hline 314 & 8760849 & -89.35120 & 29.27330 & Venice, Grand Pass & G \\
\hline 315 & 8760922 & -89.40750 & 28.93220 & Pilot Station East, SW Pass & G \\
\hline 316 & 8760943 & -89.41830 & 28.92500 & Pilot Station, SW Pass & G \\
\hline $317 *$ & 8761305 & -89.67325 & 29.86811 & Shell Beach, Lake Borgne & G \\
\hline $318 *$ & 8761529 & -89.83500 & 29.94500 & Martello Castle, Lake Borgne & G \\
\hline 319 & 8761819 & -90.03830 & 29.40170 & Texaco Dock, Hackberry Bay & G \\
\hline $320 *$ & 8761927 & -90.11342 & 30.02717 & U.S.C.G. New Canal, Lake Pont. & G \\
\hline $321 * *$ & 8762075 & -90.20860 & 29.11430 & Port Fourchon, Belle Pass & G \\
\hline 322 & 8763535 & -90.97600 & 29.17390 & Texas Gas Platform, Caillou Bay & G \\
\hline $323 * *$ & 8764025 & -91.23000 & 29.74330 & Stouts Pass At Six Mile Lake & G \\
\hline $324^{* *}$ & 8764044 & -91.23750 & 29.66750 & Berwick, Atchafalaya River, La & G \\
\hline 325 & 8764227 & -91.33810 & 29.45500 & Lawma, Amerada Pass & $\mathrm{G}$ \\
\hline 326 & 8764311 & -91.38500 & 29.37170 & Eugene Island & G \\
\hline 327 & 8765251 & -91.88000 & 29.71336 & Cypremort Point & $\mathrm{G}$ \\
\hline $328 *$ & 8767816 & -93.22167 & 30.22364 & Lake Charles, Calcasieu River & G \\
\hline 329 & 8767961 & -93.30069 & 30.19031 & Bulk Terminal \#1 & G \\
\hline 330 & 8768094 & -93.34289 & 29.76817 & Calcasieu Pass, East Jetty & G \\
\hline $331 * *$ & 8770475 & -93.93130 & 29.86670 & Port Arthur, Sabine Naches Canal & G \\
\hline $332 * *$ & 8770520 & -93.88170 & 29.98000 & Rainbow Bridge, Neches River & G \\
\hline $333 * *$ & 8770539 & -93.89500 & 29.76670 & Mesquite Point & G \\
\hline $334 * *$ & 8770559 & -94.69040 & 29.71330 & Round Point, Trinity Bay & G \\
\hline $335 * *$ & 8770570 & -93.87010 & 29.72840 & Sabine Pass North & G \\
\hline $336 * *$ & 8770597 & -93.72170 & 30.09830 & Orange (Old Navy Base) & G \\
\hline $337 * *$ & 8770613 & -94.98500 & 29.68170 & Morgans Point, Barbours Cut & G \\
\hline $338 * *$ & 8770625 & -94.86830 & 29.68000 & Umbrella Point, Trinity Bay & G \\
\hline $339 * *$ & 8770733 & -95.07830 & 29.76500 & Lynchburg Landing, San Jacinto R & G \\
\hline $340 * *$ & 8770743 & -95.09000 & 29.75670 & Battleship Texas, Houston Ship Ch & G \\
\hline
\end{tabular}


Table A1. Cont.

\begin{tabular}{|c|c|c|c|c|c|}
\hline ID & CO-OPS & Longitude & Latitude & Station Name & Region \\
\hline $341^{* *}$ & 8770777 & -95.26580 & 29.72580 & Manchester, Houston Ship Ch & G \\
\hline 342 & 8770822 & -93.83694 & 29.67806 & Texas Point, Sabine Pass & G \\
\hline $343^{* *}$ & 8770933 & -95.06670 & 29.56330 & Clear Lake & G \\
\hline $344^{* *}$ & 8770971 & -94.51330 & 29.51500 & Rollover Pass & G \\
\hline $345^{* *}$ & 8771013 & -94.91830 & 29.48000 & Eagle Point, Galveston Bay & $\mathrm{G}$ \\
\hline 346 & 8771081 & -93.64000 & 29.49830 & Sabine Offshore & G \\
\hline $347 * *$ & 8771328 & -94.78000 & 29.36500 & Port Bolivar, Bolivar Roads & G \\
\hline 348 & 8771341 & -94.72483 & 29.35733 & Galveston Bay Ent North Jetty & G \\
\hline $349 * *$ & 8771450 & -94.79330 & 29.31000 & Galveston Pier 21 & G \\
\hline 350 & 8771510 & -94.78940 & 29.28530 & Galveston Pleasure Pier, GoMex & G \\
\hline $351 * *$ & 8772440 & -95.30830 & 28.94830 & Freeport, Dow Barge Canal & G \\
\hline $352 * *$ & 8772447 & -95.30250 & 28.94310 & U.S.C.G. Freeport, Entr Channel & G \\
\hline $353 * *$ & 8773037 & -96.71170 & 28.40800 & Seadrift, San Antonio Bay & G \\
\hline $354^{* *}$ & 8773259 & -96.59500 & 28.64000 & Port Lavaca, Lavaca Causeway & G \\
\hline $355^{* *}$ & 8773701 & -96.38830 & 28.45170 & Port O'Connor, Matagorda Bay & G \\
\hline $356^{* *}$ & 8774513 & -97.02170 & 28.11830 & Copano Bay State Fishing Pier & G \\
\hline $357 * *$ & 8774770 & -97.04670 & 28.02170 & Rockport, Aransas Bay & G \\
\hline $358 * *$ & 8775188 & -97.47500 & 27.85830 & White Point Bay & G \\
\hline $359 * *$ & 8775237 & -97.07330 & 27.83890 & Port Aransas & G \\
\hline 360 & 8775270 & -97.05000 & 27.82670 & Port Aransas, H. Caldwell Pier & G \\
\hline $361 * *$ & 8775283 & -97.20330 & 27.82130 & Port Ingleside, Corpus Christi Bay & G \\
\hline $362 * *$ & 8775296 & -97.39000 & 27.81170 & Texas State Aquarium, Corpus & G \\
\hline $363 * *$ & 8775421 & -97.28000 & 27.70500 & Corpus Christi Naval Air Station & G \\
\hline $364^{* *}$ & 8775792 & -97.23670 & 27.63330 & Packery Channel & G \\
\hline 365 & 8775870 & -97.21670 & 27.58000 & Corpus Christi, Gulf Of Mexico & G \\
\hline $366^{* *}$ & 8779748 & -97.17670 & 26.07670 & South Padre Island (U.S.C.G) & G \\
\hline 367 & 8779750 & -97.15670 & 26.06830 & Padre Island, Brazos Santiago Pass & G \\
\hline $368^{* *}$ & 8779770 & -97.21500 & 26.06000 & Port Isabel, Laguna Madre & $\mathrm{G}$ \\
\hline 369 & 9500966 & -97.78050 & 22.26200 & Madero, Tampico Harbor, Mexico & G \\
\hline 370 & 9650593 & -87.87000 & 15.89300 & Puerto Cortes & $\mathrm{C}$ \\
\hline 371 & 9710441 & -78.99700 & 26.71000 & Settlement Point, Grand Bahamas & $\mathrm{C}$ \\
\hline 372 & 9751309 & -64.72100 & 18.36800 & Leinster Point (Bay), St. John & $\mathrm{C}$ \\
\hline $373 *$ & 9751364 & -64.70500 & 17.75000 & Christiansted, St. Croix Island & $\mathrm{C}$ \\
\hline $374 * *$ & 9751373 & -64.71480 & 18.34560 & St John'S Island, Coral Harbor & $\mathrm{C}$ \\
\hline $375^{* *}$ & 9751381 & -64.72400 & 18.31800 & Lameshur Bay, St. John & $\mathrm{C}$ \\
\hline 376 & 9751401 & -64.75410 & 17.69500 & Lime Tree Bay, St Croix & $\mathrm{C}$ \\
\hline 377 & 9751467 & -64.80400 & 18.36090 & Lovango Cay, St John & $\mathrm{C}$ \\
\hline 378 & 9751494 & -64.81800 & 18.29700 & Dog Island, St Thomas & $\mathrm{C}$ \\
\hline $379 * *$ & 9751567 & -64.86905 & 18.31870 & Benner Bay & $\mathrm{C}$ \\
\hline 380 & 9751583 & -64.86400 & 18.34870 & Water Bay, Saint Thomas & $\mathrm{C}$ \\
\hline $381 *$ & 9751584 & -64.88400 & 17.71300 & Fredericksted, St. Croix Island & $\mathrm{C}$ \\
\hline $382 * *$ & 9751639 & -64.92030 & 18.33570 & Charlotte Amalie, St. Thomas & $\mathrm{C}$ \\
\hline $383 *$ & 9751768 & -64.96270 & 18.37110 & Ruy Point, St Thomas & $\mathrm{C}$ \\
\hline $384 *$ & 9751774 & -65.03500 & 18.36300 & Botany Bay, St Thomas & $\mathrm{C}$ \\
\hline 385 & 9752235 & -65.30200 & 18.30100 & Culebra & $\mathrm{C}$ \\
\hline 386 & 9752619 & -65.44400 & 18.15300 & Isabel Segunda, Vieques Island & $\mathrm{C}$ \\
\hline $387 *$ & 9752695 & -65.47100 & 18.09395 & Esperanza, Vieques Island & $\mathrm{C}$ \\
\hline 388 & 9752962 & -65.57000 & 18.34500 & Isla Palominos & $\mathrm{C}$ \\
\hline $389 *$ & 9753216 & -65.63100 & 18.33500 & Playa De Fajardo & $\mathrm{C}$ \\
\hline $390 *$ & 9753641 & -65.71102 & 18.18700 & Naguabo & $\mathrm{C}$ \\
\hline $391 *$ & 9754228 & -65.83300 & 18.05500 & Yabucoa Harbor & $\mathrm{C}$ \\
\hline $392 * *$ & 9755371 & -66.11600 & 18.45900 & San Juan, La Puntilla, San Juan Bay & $\mathrm{C}$ \\
\hline 393 & 9755679 & -66.15800 & 17.92800 & Las Mareas & $\mathrm{C}$ \\
\hline $394 *$ & 9756639 & -66.40700 & 17.95390 & Santa Isabel & $\mathrm{C}$ \\
\hline 395 & 9757809 & -66.70210 & 18.48140 & Arecibo, Puerto Rico & $\mathrm{C}$ \\
\hline 396 & 9758053 & -66.76200 & 17.97300 & Penuelas, Punta Guayanilla & $\mathrm{C}$ \\
\hline
\end{tabular}


Table A1. Cont.

\begin{tabular}{|c|c|c|c|c|c|}
\hline ID & CO-OPS & Longitude & Latitude & Station Name & Region \\
\hline $397 * *$ & 9759110 & -67.04603 & 17.97000 & Magueyes Island & $\mathrm{C}$ \\
\hline $398 * *$ & 9759189 & -67.18900 & 18.07500 & Puerto Real & $\mathrm{C}$ \\
\hline $399 * *$ & 9759197 & -67.19700 & 17.95100 & Bahia Salinas & $\mathrm{C}$ \\
\hline $400 *$ & 9759394 & -67.16080 & 18.21790 & Mayaguez, Puerto Rico & $\mathrm{C}$ \\
\hline 401 & 9759412 & -67.16500 & 18.45700 & Aguadilla, Crashboat Beach & $\mathrm{C}$ \\
\hline 402 & 9759421 & -67.18530 & 18.16500 & Punta Guanajabo, Mayagues & $\mathrm{C}$ \\
\hline 403 & 9759938 & -67.93900 & 18.09000 & Mona Island & $\mathrm{C}$ \\
\hline $404 *$ & 9761115 & -61.82100 & 17.59040 & Barbuda & $\mathrm{C}$ \\
\hline 405 & $\mathrm{IHO}$ & -66.05000 & 45.23330 & Partridge Island & $\mathrm{A}$ \\
\hline 406 & $\mathrm{IHO}$ & -67.04999 & 45.06667 & St Andrews & $\mathrm{A}$ \\
\hline 407 & $\mathrm{IHO}$ & -66.86667 & 45.04583 & Back Bay & $\mathrm{A}$ \\
\hline 408 & $\mathrm{IHO}$ & -65.06665 & 45.05000 & Margretsville & $\mathrm{A}$ \\
\hline 409 & $\mathrm{IHO}$ & -67.01711 & 44.96622 & Fairhaven & $\mathrm{A}$ \\
\hline 410 & $\mathrm{IHO}$ & -66.98333 & 44.90000 & Eastport & $\mathrm{A}$ \\
\hline 411 & $\mathrm{IHO}$ & -66.95354 & 44.88334 & Welshpool & $\mathrm{A}$ \\
\hline 412 & $\mathrm{IHO}$ & -62.75896 & 44.77344 & Murphy Cove & $\mathrm{A}$ \\
\hline $413 * *$ & $\mathrm{IHO}$ & -66.75010 & 44.76557 & North Head & $\mathrm{A}$ \\
\hline 414 & $\mathrm{IHO}$ & -65.83334 & 44.66667 & Deep Cove & A \\
\hline 415 & $\mathrm{IHO}$ & -63.56712 & 44.64378 & Halifax & $\mathrm{A}$ \\
\hline 416 & $\mathrm{IHO}$ & -66.79999 & 44.60000 & Outer Wood Island & $\mathrm{A}$ \\
\hline 417 & $\mathrm{IHO}$ & -63.95001 & 44.49900 & Indian Harbour & $\mathrm{A}$ \\
\hline $418^{* *}$ & $\mathrm{IHO}$ & -66.10001 & 44.46390 & Sandy Cove & A \\
\hline $419^{* *}$ & $\mathrm{IHO}$ & -68.20001 & 44.40000 & Bar Harbour & $\mathrm{A}$ \\
\hline 420 & $\mathrm{IHO}$ & -68.01666 & 44.40000 & Prospect Harbour & $\mathrm{A}$ \\
\hline 421 & $\mathrm{IHO}$ & -66.39999 & 44.25000 & Lighthouse Cove & $\mathrm{A}$ \\
\hline 422 & $\mathrm{IHO}$ & -66.16666 & 44.20000 & Meteghan & $\mathrm{A}$ \\
\hline 423 & $\mathrm{IHO}$ & -68.88333 & 44.14642 & Pulpit Harbour & A \\
\hline 424 & $\mathrm{IHO}$ & -64.66210 & 43.98320 & Liverpool & $\mathrm{A}$ \\
\hline 425 & $\mathrm{IHO}$ & -65.10420 & 43.66480 & Lockeport & $\mathrm{A}$ \\
\hline $426^{* *}$ & $\mathrm{IHO}$ & -70.24667 & 43.65667 & Portland & A \\
\hline 427 & $\mathrm{IHO}$ & -65.74290 & 43.52580 & Woods Harbour & $\mathrm{A}$ \\
\hline 428 & $\mathrm{IHO}$ & -66.00000 & 43.50000 & Flat Island & $\mathrm{A}$ \\
\hline 429 & $\mathrm{IHO}$ & -66.00000 & 43.48333 & Seal Island & $\mathrm{A}$ \\
\hline $430 * *$ & $\mathrm{IHO}$ & -70.74167 & 43.08000 & Portsmouth (Navy Yard) & A \\
\hline 431 & $\mathrm{IHO}$ & -63.20001 & 42.81667 & Fundy 1 & $\mathrm{~A} / \mathrm{D}$ \\
\hline 432 & $\mathrm{IHO}$ & -63.98334 & 42.78333 & SB2 & $\mathrm{A} / \mathrm{D}$ \\
\hline 433 & $\mathrm{IHO}$ & -64.36667 & 42.61666 & Fundy 21 & $\mathrm{~A} / \mathrm{D}$ \\
\hline 434 & $\mathrm{IHO}$ & -67.71667 & 42.46667 & Fundy 6 & $\mathrm{~A} / \mathrm{D}$ \\
\hline $435^{* *}$ & $\mathrm{IHO}$ & -71.03326 & 42.35078 & Boston (Commonwealth Piers) & A \\
\hline 436 & $\mathrm{IHO}$ & -65.50000 & 42.11666 & Fundy 22a & $\mathrm{A} / \mathrm{D}$ \\
\hline 437 & $\mathrm{IHO}$ & -65.63333 & 42.05000 & Fundy 22b & $\mathrm{A} / \mathrm{D}$ \\
\hline $438^{* *}$ & $\mathrm{IHO}$ & -71.39694 & 41.80080 & Providence & A \\
\hline $439 *$ & $\mathrm{IHO}$ & -70.50000 & 41.77482 & E Cape Cod Canal & A \\
\hline $440^{* *}$ & $\mathrm{IHO}$ & -70.61667 & 41.74072 & WCape Cod Canal & $\mathrm{A}$ \\
\hline $441^{* *}$ & $\mathrm{IHO}$ & -70.62512 & 41.73333 & Buzzards Bay & $\mathrm{A}$ \\
\hline 442 & $\mathrm{IHO}$ & -65.79999 & 41.73333 & Fundy 3 & $\mathrm{~A} / \mathrm{D}$ \\
\hline $443 *$ & $\mathrm{IHO}$ & -70.89999 & 41.60000 & New Bedford & A \\
\hline 444 & $\mathrm{IHO}$ & -71.33334 & 41.50000 & Newport & $\mathrm{A}$ \\
\hline 445 & $\mathrm{IHO}$ & -70.67143 & 41.52422 & Woods Hole (Ocean Inst) & $\mathrm{A}$ \\
\hline $446^{* *}$ & $\mathrm{IHO}$ & -72.09900 & 41.34903 & New London & A \\
\hline 447 & $\mathrm{IHO}$ & -72.35001 & 41.26667 & Connecticut River Ent & $\mathrm{A}$ \\
\hline $448 *$ & $\mathrm{IHO}$ & -73.16666 & 41.16667 & Bridgeport & $\mathrm{A}$ \\
\hline 449 & $\mathrm{IHO}$ & -72.20001 & 41.16521 & Plum Island & $\mathrm{A}$ \\
\hline $450 *$ & $\mathrm{IHO}$ & -71.96667 & 41.05000 & montauk & $\mathrm{A}$ \\
\hline $451 * *$ & $\mathrm{IHO}$ & -73.06728 & 40.95027 & Port Jefferson & $\mathrm{A}$ \\
\hline $452 *$ & $\mathrm{IHO}$ & -73.78333 & 40.80000 & Willets Point & A \\
\hline $453^{* *}$ & $\mathrm{IHO}$ & -73.85006 & 40.78285 & College Point & $\mathrm{A}$ \\
\hline
\end{tabular}


Table A1. Cont.

\begin{tabular}{|c|c|c|c|c|c|}
\hline ID & CO-OPS & Longitude & Latitude & Station Name & Region \\
\hline 454 & $\mathrm{IHO}$ & -66.83334 & 40.73333 & Fundy 4 & $\mathrm{~A} / \mathrm{D}$ \\
\hline $455^{* *}$ & $\mathrm{IHO}$ & -73.23280 & 40.71533 & Bayshore Long Island & A \\
\hline $456^{* *}$ & $\mathrm{IHO}$ & -74.01666 & 40.70000 & New York: Battery & $\mathrm{A}$ \\
\hline $457^{* *}$ & $\mathrm{IHO}$ & -74.01666 & 40.68333 & New York: Governor's Island & A \\
\hline 458 & $\mathrm{IHO}$ & -74.03333 & 40.60000 & New York: Fort Hamilton & A \\
\hline 459 & $\mathrm{IHO}$ & -74.01666 & 40.46833 & Sandy Hook & A \\
\hline 460 & $\mathrm{IHO}$ & -67.75000 & 40.36666 & Fundy 23 & $\mathrm{~A} / \mathrm{D}$ \\
\hline 461 & $\mathrm{IHO}$ & -70.89999 & 40.30000 & IAPSO: 30-1.2.32 & $\mathrm{A} / \mathrm{D}$ \\
\hline 462 & $\mathrm{IHO}$ & -68.63333 & 40.11667 & IAPSO: 30-1.2.1 & $\mathrm{A} / \mathrm{D}$ \\
\hline $463 * *$ & $\mathrm{IHO}$ & -75.13333 & 39.95000 & Philadelphia & A \\
\hline 464 & $\mathrm{IHO}$ & -71.38333 & 39.95000 & IAPSO: $30-1.2 .2$ & $\mathrm{~A} / \mathrm{D}$ \\
\hline $465^{* *}$ & $\mathrm{IHO}$ & -75.58334 & 39.58333 & Delaware City & A \\
\hline $466^{* *}$ & $\mathrm{IHO}$ & -75.56665 & 39.55000 & Reedy Point & A \\
\hline $467 * *$ & $\mathrm{IHO}$ & -75.81665 & 39.53140 & Chesapeake City & $\mathrm{A}$ \\
\hline $468^{* *}$ & $\mathrm{IHO}$ & -75.88333 & 39.51667 & Court House Point & A \\
\hline $469 * *$ & $\mathrm{IHO}$ & -75.98419 & 39.43576 & Elk River Entrance & A \\
\hline 470 & $\mathrm{IHO}$ & -76.26666 & 39.28333 & Pooles Island Light & A \\
\hline $471^{* *}$ & $\mathrm{IHO}$ & -76.58070 & 39.26940 & Baltimore & A \\
\hline 472 & $\mathrm{IHO}$ & -72.16666 & 39.21667 & IAPSO: 30-1.2.17 & $\mathrm{A} / \mathrm{D}$ \\
\hline 473 & $\mathrm{IHO}$ & -71.36667 & 39.16667 & IAPSO: 30-1.2.19 & $\mathrm{A} / \mathrm{D}$ \\
\hline 474 & $\mathrm{IHO}$ & -76.41666 & 39.15000 & Seven Foot Knoll Light & A \\
\hline 475 & $\mathrm{IHO}$ & -76.30221 & 39.04201 & Love Point Light & A \\
\hline $476^{* *}$ & $\mathrm{IHO}$ & -76.48191 & 38.98550 & Annapolis & A \\
\hline $477 *$ & $\mathrm{IHO}$ & -74.96000 & 38.96833 & Cape May Ferry Terminal & A \\
\hline 478 & $\mathrm{IHO}$ & -76.43335 & 38.90000 & Thomas Point Shoal Light & $\mathrm{A}$ \\
\hline $479 * *$ & $\mathrm{IHO}$ & -77.01725 & 38.86094 & Washington D.C. & A \\
\hline $480 * *$ & $\mathrm{IHO}$ & -75.10220 & 38.78790 & Breakwater Harbour & $\mathrm{A}$ \\
\hline $481^{* *}$ & $\mathrm{IHO}$ & -75.07045 & 38.60092 & Indian River Inlet & $\mathrm{A}$ \\
\hline $482 * *$ & $\mathrm{IHO}$ & -76.06341 & 38.57254 & Cambridge & A \\
\hline $483 * *$ & $\mathrm{IHO}$ & -76.45001 & 38.31667 & Solomons Island & A \\
\hline $484^{* *}$ & $\mathrm{IHO}$ & -76.41666 & 38.31667 & Drum Point Light & $\mathrm{A}$ \\
\hline 485 & $\mathrm{IHO}$ & -76.95001 & 38.25000 & Colonial Beach & A \\
\hline 486 & $\mathrm{IHO}$ & -76.75000 & 38.21667 & Colton Point & A \\
\hline 487 & $\mathrm{IHO}$ & -76.53333 & 38.13334 & Piney Point & $\mathrm{A}$ \\
\hline 488 & $\mathrm{IHO}$ & -76.10001 & 38.06667 & Holland Island Bar Light & $\mathrm{A}$ \\
\hline 489 & $\mathrm{IHO}$ & -76.26666 & 37.80000 & Great Wicomico Light & A \\
\hline 490 & $\mathrm{IHO}$ & -76.26666 & 37.56667 & Stingray Point Light & $\mathrm{A}$ \\
\hline 491 & $\mathrm{IHO}$ & -73.08334 & 37.36666 & IAPSO: 30-1.2.16 & $\mathrm{A} / \mathrm{D}$ \\
\hline $492 * *$ & $\mathrm{IHO}$ & -77.26666 & 37.31667 & City Point Hopewell & A \\
\hline $493^{* *}$ & $\mathrm{IHO}$ & -76.02449 & 37.26667 & Cape Charles & A \\
\hline $494^{* *}$ & $\mathrm{IHO}$ & -76.49882 & 37.24811 & Gloucester Point & A \\
\hline 495 & $\mathrm{IHO}$ & -76.29999 & 37.00000 & Old Point Comfort & A \\
\hline $496^{* *}$ & $\mathrm{IHO}$ & -76.33334 & 36.95000 & Hampton Roads (Sewall Pt.) & $\mathrm{A}$ \\
\hline 497 & $\mathrm{IHO}$ & -75.96667 & 36.83333 & Virginia Beach & A \\
\hline 498 & $\mathrm{IHO}$ & -75.50000 & 35.33333 & Avon & $\mathrm{A}$ \\
\hline $499 *$ & $\mathrm{IHO}$ & -76.68335 & 34.71667 & Morehead City & A \\
\hline $500 * *$ & $\mathrm{IHO}$ & -77.95001 & 34.23333 & Wilmington & A \\
\hline $501 *$ & $\mathrm{IHO}$ & -78.01667 & 33.91500 & Southport & $\mathrm{A}$ \\
\hline 502 & $\mathrm{IHO}$ & -78.89999 & 33.66667 & Myrtle Beach & $\mathrm{A}$ \\
\hline $503 * *$ & $\mathrm{IHO}$ & -79.91666 & 32.78333 & Charleston & $\mathrm{A}$ \\
\hline 504 & $\mathrm{IHO}$ & -75.61667 & 32.68333 & IAPSO: 30-1.2.3 & $\mathrm{A} / \mathrm{D}$ \\
\hline 505 & $\mathrm{IHO}$ & -64.64999 & 32.36666 & St. Davids Island & A \\
\hline $506^{* *}$ & $\mathrm{IHO}$ & -80.78279 & 32.31757 & Port Royal Sound & A \\
\hline 507 & $\mathrm{IHO}$ & -64.83334 & 32.31667 & Ireland Island & $\mathrm{A}$ \\
\hline $508 * *$ & $\mathrm{IHO}$ & -80.89995 & 32.03360 & Savannah River Entrance & A \\
\hline 509 & $\mathrm{IHO}$ & -64.43335 & 32.01667 & IAPSO: $30-1.2 .18$ & $\mathrm{~A} / \mathrm{D}$ \\
\hline $510 * *$ & $\mathrm{IHO}$ & -81.20050 & 31.53659 & Sapelo Sound & A \\
\hline
\end{tabular}


Table A1. Cont.

\begin{tabular}{|c|c|c|c|c|c|}
\hline ID & CO-OPS & Longitude & Latitude & Station Name & Region \\
\hline $511 * *$ & $\mathrm{IHO}$ & -88.04010 & 30.70830 & Mobile & G \\
\hline 512 & $\mathrm{IHO}$ & -76.41666 & 30.43333 & IAPSO: 30-1.2.11 & $\mathrm{A} / \mathrm{D}$ \\
\hline $513 * *$ & $\mathrm{IHO}$ & -88.90330 & 30.41175 & Biloxi & G \\
\hline $514^{* *}$ & $\mathrm{IHO}$ & -87.21667 & 30.40000 & Pensacola & G \\
\hline $515 *$ & $\mathrm{IHO}$ & -81.43259 & 30.39928 & Mayport & A \\
\hline $516^{* *}$ & $\mathrm{IHO}$ & -87.26428 & 30.34872 & Warrington Navy Yard & G \\
\hline $517^{* *}$ & $\mathrm{IHO}$ & -81.61667 & 30.35000 & Jacksonville Dredger Dept. & A \\
\hline 518 & $\mathrm{IHO}$ & -90.29999 & 30.29805 & Pass Nanchac Light & G \\
\hline 519 & $\mathrm{IHO}$ & -89.33334 & 30.30000 & Bay St Louis & G \\
\hline 520 & $\mathrm{IHO}$ & -89.16666 & 30.23333 & Cat Island & G \\
\hline $521 * *$ & $\mathrm{IHO}$ & -88.01666 & 30.23333 & Mobile Point Light & G \\
\hline $522 * *$ & $\mathrm{IHO}$ & -85.74736 & 30.16939 & Alligator Bayou & $\mathrm{G}$ \\
\hline 523 & $\mathrm{IHO}$ & -84.18335 & 30.06667 & St Marks Light & $\mathrm{G}$ \\
\hline 524 & $\mathrm{IHO}$ & -90.11667 & 30.02376 & West End & G \\
\hline $525 * *$ & $\mathrm{IHO}$ & -90.06803 & 29.91999 & New Orleans & G \\
\hline 526 & $\mathrm{IHO}$ & -93.34736 & 29.78333 & Calcasieu Pass Light & G \\
\hline $527 * *$ & $\mathrm{IHO}$ & -94.69040 & 29.71333 & Round Point & G \\
\hline 528 & $\mathrm{IHO}$ & -84.98334 & 29.71667 & Apalachicola & G \\
\hline 529 & $\mathrm{IHO}$ & -93.85001 & 29.70000 & Sabine & $\mathrm{G}$ \\
\hline $530 * *$ & $\mathrm{IHO}$ & -94.98334 & 29.68333 & Morgan Point & G \\
\hline $531 *$ & $\mathrm{IHO}$ & -94.49038 & 29.51828 & Gilchrist & G \\
\hline 532 & $\mathrm{IHO}$ & -92.03492 & 29.57862 & Lighthouse Point & G \\
\hline $533^{* *}$ & $\mathrm{IHO}$ & -91.54999 & 29.51667 & Point Chevreuil & G \\
\hline 534 & $\mathrm{IHO}$ & -91.76710 & 29.48820 & South Point & G \\
\hline 535 & $\mathrm{IHO}$ & -89.16666 & 29.48333 & Breton Island & G \\
\hline 536 ** & $\mathrm{IHO}$ & -91.27077 & 29.51204 & Shell Island & G \\
\hline 537 & $\mathrm{IHO}$ & -91.59734 & 29.50966 & Rabbit Island Pass & $\mathrm{G}$ \\
\hline 538 & $\mathrm{IHO}$ & -91.38500 & 29.37170 & Eugene Island & G \\
\hline $539^{* *}$ & $\mathrm{IHO}$ & -89.33334 & 29.36667 & Jack Bay & G \\
\hline 540 & $\mathrm{IHO}$ & -94.70001 & 29.33333 & Galveston Bay Entrance & G \\
\hline 541 & $\mathrm{IHO}$ & -91.75000 & 29.28667 & Point au Fer & G \\
\hline $542 * *$ & $\mathrm{IHO}$ & -94.78333 & 29.31667 & Galveston & G \\
\hline $543^{* *}$ & $\mathrm{IHO}$ & -89.96667 & 29.26667 & Bayou Rigaud & $\mathrm{G}$ \\
\hline 544 & $\mathrm{IHO}$ & -89.60001 & 29.25000 & Empire Jetty & $\mathrm{G}$ \\
\hline 545 & $\mathrm{IHO}$ & -81.00000 & 29.23333 & Daytona Beach & $\mathrm{A}$ \\
\hline $546^{* *}$ & $\mathrm{IHO}$ & -95.00000 & 29.21667 & Carancahua Reef & G \\
\hline 547 & $\mathrm{IHO}$ & -89.04999 & 29.21667 & Lonesome Bayou & G \\
\hline $548^{* *}$ & $\mathrm{IHO}$ & -81.00000 & 29.21667 & Daytona Beach & A \\
\hline 549 & $\mathrm{IHO}$ & -83.03167 & 29.13333 & Cedar Kay & G \\
\hline 550 & $\mathrm{IHO}$ & -89.03333 & 29.11667 & Southeast Pass & G \\
\hline 551 & $\mathrm{IHO}$ & -89.26666 & 29.05000 & Joseph Bayou & $\mathrm{G}$ \\
\hline 552 & $\mathrm{IHO}$ & -89.16666 & 29.01667 & Port Eads & $\mathrm{G}$ \\
\hline 553 & $\mathrm{IHO}$ & -89.13333 & 28.98333 & South Pass & $\mathrm{G}$ \\
\hline 554 & $\mathrm{IHO}$ & -95.29999 & 28.93333 & Freeport & $\mathrm{G}$ \\
\hline 555 & $\mathrm{IHO}$ & -89.42833 & 28.93167 & Southwest Pass & G \\
\hline $556 *$ & $\mathrm{IHO}$ & -82.66874 & 28.45132 & Indian Bay & $\mathrm{G}$ \\
\hline 557 & $\mathrm{IHO}$ & -76.79999 & 28.45000 & IAPSO: $30-1.2 .15$ & $\mathrm{~A} / \mathrm{D}$ \\
\hline 558 & $\mathrm{IHO}$ & -67.53333 & 28.23333 & IAPSO: $30-1.2 .5$ & $\mathrm{~A} / \mathrm{D}$ \\
\hline 559 & $\mathrm{IHO}$ & -69.75000 & 28.13333 & IAPSO: $30-1.2 .4$ & $\mathrm{~A} / \mathrm{D}$ \\
\hline $560 * *$ & $\mathrm{IHO}$ & -97.04999 & 28.01667 & Rockport & $\mathrm{G}$ \\
\hline 561 & $\mathrm{IHO}$ & -76.78333 & 28.01667 & IAPSO: 30-1.2.14 & $\mathrm{A} / \mathrm{D}$ \\
\hline 562 & $\mathrm{IHO}$ & -69.66666 & 27.98333 & IAPSO: $30-1.2 .8$ & $\mathrm{~A} / \mathrm{D}$ \\
\hline 563 & $\mathrm{IHO}$ & -69.66666 & 27.96667 & IAPSO: 30-1.2.7 & $\mathrm{A} / \mathrm{D}$ \\
\hline $564^{* *}$ & $\mathrm{IHO}$ & -97.39999 & 27.81493 & Nueces Bay & G \\
\hline 565 & $\mathrm{IHO}$ & -82.61667 & 27.76667 & St Petersburg & G \\
\hline $566^{*}$ & $\mathrm{IHO}$ & -82.73295 & 27.53391 & Anna Maria & $\mathrm{G}$ \\
\hline $567^{* *}$ & $\mathrm{IHO}$ & -82.25000 & 26.71667 & South Boca Grande & G \\
\hline 568 & $\mathrm{IHO}$ & -84.25000 & 26.70000 & IAPSO: $30-1.2 .13$ & $G / D$ \\
\hline
\end{tabular}


Table A1. Cont.

\begin{tabular}{|c|c|c|c|c|c|}
\hline ID & CO-OPS & Longitude & Latitude & Station Name & Region \\
\hline $569^{* *}$ & $\mathrm{IHO}$ & -81.86667 & 26.65000 & Fort Myers & $\mathrm{G}$ \\
\hline $570 * *$ & $\mathrm{IHO}$ & -82.06665 & 26.63333 & Matlacha Pass & G \\
\hline $571 * *$ & $\mathrm{IHO}$ & -82.08081 & 26.55000 & Tropical Homesites & G \\
\hline $572 * *$ & $\mathrm{IHO}$ & -82.18335 & 26.51667 & Captiva Island & $\mathrm{G}$ \\
\hline $573^{* *}$ & $\mathrm{IHO}$ & -82.08334 & 26.48333 & St James City & G \\
\hline $574^{* *}$ & $\mathrm{IHO}$ & -82.01666 & 26.48333 & Punta Rassa & G \\
\hline 575 & $\mathrm{IHO}$ & -69.33334 & 26.46667 & IAPSO: $30-1.2 .13$ & $\mathrm{~A} / \mathrm{D}$ \\
\hline $576^{* *}$ & $\mathrm{IHO}$ & -81.95001 & 26.45511 & Matanzas Pass & G \\
\hline $577 * *$ & $\mathrm{IHO}$ & -81.93335 & 26.45000 & Hurricane Bay San Carlos & G \\
\hline 578 & $\mathrm{IHO}$ & -69.31665 & 26.45000 & IAPSO: $30-1.2 .9$ & $\mathrm{~A} / \mathrm{D}$ \\
\hline $579 * *$ & $\mathrm{IHO}$ & -81.90951 & 26.43333 & Estero Island Estero Bay & G \\
\hline $580 * *$ & $\mathrm{IHO}$ & -81.85938 & 26.43120 & Mound Key Estero Bay & $\mathrm{G}$ \\
\hline $581 * *$ & $\mathrm{IHO}$ & -81.89248 & 26.41690 & Ostego Bay & $\mathrm{G}$ \\
\hline $582 * *$ & $\mathrm{IHO}$ & -81.88324 & 26.40748 & Carlos Point Estero Bay & G \\
\hline $583^{* *}$ & $\mathrm{IHO}$ & -97.35001 & 26.35000 & North Point & $\mathrm{G}$ \\
\hline $584^{* *}$ & $\mathrm{IHO}$ & -97.21500 & 26.06000 & Port Isabel & G \\
\hline 585 & $\mathrm{IHO}$ & -97.14999 & 26.06667 & South Padre Island & G \\
\hline 586 & $\mathrm{IHO}$ & -79.89999 & 25.85000 & IAPSO: $30-1.2 .12$ & $\mathrm{~A} / \mathrm{D}$ \\
\hline 587 & $\mathrm{IHO}$ & -79.28333 & 25.55000 & Cat Cay & A \\
\hline 588 & $\mathrm{IHO}$ & -77.35001 & 25.08333 & Nassau & A \\
\hline 589 & $\mathrm{IHO}$ & -77.96208 & 25.04691 & Anros Island & A \\
\hline 590 & $\mathrm{IHO}$ & -76.15000 & 24.76667 & Eleuthera & A \\
\hline 591 & $\mathrm{IHO}$ & -89.64999 & 24.76667 & IAPSO: $30-1.2 .6$ & G/D \\
\hline 592 & $\mathrm{IHO}$ & -80.93335 & 24.76667 & Grassy Key & A \\
\hline $593 * *$ & $\mathrm{IHO}$ & -81.01666 & 24.71667 & Marathon Shores & $\mathrm{A}$ \\
\hline 594 & $\mathrm{IHO}$ & -82.88333 & 24.63333 & Tortugas & G \\
\hline 595 & $\mathrm{IHO}$ & -81.79994 & 24.54559 & Key West & $\mathrm{G}$ \\
\hline 596 & $\mathrm{IHO}$ & -75.96631 & 23.66719 & Steventon Great Exuma & A \\
\hline 597 & $\mathrm{IHO}$ & -82.33334 & 23.17150 & Habana & G \\
\hline 598 & $\mathrm{IHO}$ & -74.95001 & 23.00000 & Long Island & A \\
\hline 599 & $\mathrm{IHO}$ & -73.04999 & 22.33333 & Start Point Mayaguana & $\mathrm{A}$ \\
\hline 600 & $\mathrm{IHO}$ & -97.76990 & 22.25000 & Tampico & G \\
\hline 601 & $\mathrm{IHO}$ & -74.29999 & 22.16667 & Datum Bay & $\mathrm{A}$ \\
\hline 602 & $\mathrm{IHO}$ & -79.97908 & 21.72682 & Casilda & $\mathrm{C}$ \\
\hline 603 & $\mathrm{IHO}$ & -82.91677 & 21.44490 & Carapachibey & $\mathrm{C}$ \\
\hline 604 & $\mathrm{IHO}$ & -71.14999 & 21.43333 & Grand Turk & A \\
\hline 605 & $\mathrm{IHO}$ & -89.65000 & 21.30000 & Progreso & G \\
\hline 606 & $\mathrm{IHO}$ & -76.10860 & 21.11580 & Gibara & A \\
\hline 607 & $\mathrm{IHO}$ & -74.49380 & 20.36023 & Baracoa & $\mathrm{A}$ \\
\hline 608 & $\mathrm{IHO}$ & -75.14999 & 19.89300 & Guantanamo Bay & $\mathrm{C}$ \\
\hline 609 & $\mathrm{IHO}$ & -90.55310 & 19.85580 & Campeche & $\mathrm{G}$ \\
\hline 610 & $\mathrm{IHO}$ & -70.65910 & 19.78300 & Puerto Plata & $\mathrm{A}$ \\
\hline $611^{* *}$ & $\mathrm{IHO}$ & -69.31665 & 19.19590 & Samana & A \\
\hline 612 & $\mathrm{IHO}$ & -96.11160 & 19.18333 & Vera Cruz & G \\
\hline $613^{* *}$ & $\mathrm{IHO}$ & -64.38333 & 18.72501 & Anegada & A \\
\hline 614 & $\mathrm{IHO}$ & -72.35384 & 18.55022 & Port au Prince & $\mathrm{C}$ \\
\hline $615^{* *}$ & $\mathrm{IHO}$ & -69.88333 & 18.46527 & Ciudad Trujillo & $\mathrm{C}$ \\
\hline $616^{* *}$ & $\mathrm{IHO}$ & -66.11600 & 18.45900 & San Juan & $\mathrm{A}$ \\
\hline $617^{* *}$ & $\mathrm{IHO}$ & -64.61667 & 18.42723 & Tortola & $\mathrm{C}$ \\
\hline $618^{* *}$ & $\mathrm{IHO}$ & -68.95001 & 18.41036 & La Romana & $\mathrm{C}$ \\
\hline $619 *$ & $\mathrm{IHO}$ & -64.93335 & 18.33333 & St Thomas & $\mathrm{C}$ \\
\hline 620 & $\mathrm{IHO}$ & -65.28333 & 18.30000 & Great Harbor & $\mathrm{C}$ \\
\hline 621 & $\mathrm{IHO}$ & -78.13333 & 18.20000 & Savanna la Mar & $\mathrm{C}$ \\
\hline 622 & $\mathrm{IHO}$ & -94.41666 & 18.15805 & Coatzacoalcos & $\mathrm{G}$ \\
\hline $623^{* *}$ & $\mathrm{IHO}$ & -67.04603 & 17.97000 & Magueyes Island & $\mathrm{C}$ \\
\hline $624^{* *}$ & $\mathrm{IHO}$ & -61.85111 & 17.12284 & St Johns & $\mathrm{C}$ \\
\hline 625 & $\mathrm{IHO}$ & -64.88333 & 16.53333 & IAPSO: $30-1.3 .2$ & $\mathrm{C} / \mathrm{D}$ \\
\hline 626 & $\mathrm{IHO}$ & -64.91666 & 16.50000 & IAPSO: $30-1.3 .1$ & $\mathrm{C} / \mathrm{D}$ \\
\hline
\end{tabular}


Table A1. Cont.

\begin{tabular}{|c|c|c|c|c|c|}
\hline ID & CO-OPS & Longitude & Latitude & Station Name & Region \\
\hline $627^{* *}$ & $\mathrm{IHO}$ & -61.50000 & 16.38333 & Petit Canal & $\mathrm{C}$ \\
\hline $628 *$ & $\mathrm{IHO}$ & -61.69943 & 16.33476 & Sainte Rose & $\mathrm{C}$ \\
\hline 629 & $\mathrm{IHO}$ & -61.26666 & 16.25000 & Saint Francois & $\mathrm{C}$ \\
\hline 630 & $\mathrm{IHO}$ & -61.53702 & 16.23290 & Pointe a Pitre & $\mathrm{C}$ \\
\hline 631 & $\mathrm{IHO}$ & -87.95001 & 15.83333 & Puerto Cortes & $\mathrm{C}$ \\
\hline $632 *$ & $\mathrm{IHO}$ & -61.46667 & 15.56667 & Portsmouth & $\mathrm{C}$ \\
\hline 633 & $\mathrm{IHO}$ & -61.04999 & 14.58333 & Fort de France & $\mathrm{C}$ \\
\hline 634 & $\mathrm{IHO}$ & -83.36667 & 14.01667 & Puerto Cabezas & $\mathrm{C}$ \\
\hline 635 & $\mathrm{IHO}$ & -61.00110 & 14.02240 & Castries & $\mathrm{C}$ \\
\hline 636 & $\mathrm{IHO}$ & -61.23334 & 13.13333 & Kingstown St Vincent & $\mathrm{C}$ \\
\hline $637^{* *}$ & $\mathrm{IHO}$ & -59.61454 & 13.08616 & Carlisle Bay & $\mathrm{A}$ \\
\hline 638 & $\mathrm{IHO}$ & -61.18335 & 12.83333 & Mustique Grand Bay & C \\
\hline 639 & $\mathrm{IHO}$ & -61.33334 & 12.70329 & Charlestown Bay & $\mathrm{C}$ \\
\hline 640 & $\mathrm{IHO}$ & -61.35001 & 12.63333 & Tobago Cays & $\mathrm{C}$ \\
\hline 641 & $\mathrm{IHO}$ & -70.05290 & 12.60000 & Aruba Malmok Bay & $\mathrm{C}$ \\
\hline 642 & $\mathrm{IHO}$ & -61.41778 & 12.59252 & Clifton Harbour & $\mathrm{C}$ \\
\hline 643 & $\mathrm{IHO}$ & -70.03554 & 12.51347 & Aruba Oranjestad & $\mathrm{C}$ \\
\hline 644 & $\mathrm{IHO}$ & -61.45709 & 12.48783 & Hillsborough Bay & $\mathrm{C}$ \\
\hline 645 & $\mathrm{IHO}$ & -68.93335 & 12.10000 & Curacao Willemstad & $\mathrm{C}$ \\
\hline $646 *$ & $\mathrm{IHO}$ & -61.75652 & 12.05000 & St Georges & $\mathrm{C}$ \\
\hline 647 & $\mathrm{IHO}$ & -68.64999 & 12.00000 & Klein Curacao n.w. Coast & $\mathrm{C}$ \\
\hline $648 *$ & $\mathrm{IHO}$ & -70.21667 & 11.75000 & Amuay & $\mathrm{C}$ \\
\hline $649 *$ & $\mathrm{IHO}$ & -60.73360 & 11.16920 & Scarborough & $\mathrm{A}$ \\
\hline 650 & $\mathrm{IHO}$ & -71.64651 & 11.02353 & Zaparita & $\mathrm{C}$ \\
\hline 651 & $\mathrm{IHO}$ & -71.58334 & 11.00000 & Malecon & $\mathrm{C}$ \\
\hline 652 & $\mathrm{IHO}$ & -71.56665 & 10.96667 & Zapara Island & $\mathrm{C}$ \\
\hline 653 & $\mathrm{IHO}$ & -71.61667 & 10.88333 & Tablazo & $\mathrm{C}$ \\
\hline 654 & $\mathrm{IHO}$ & -60.93335 & 10.83689 & Toco & $\mathrm{A}$ \\
\hline 655 & $\mathrm{IHO}$ & -71.63333 & 10.81667 & Punta Palmas & $\mathrm{C}$ \\
\hline $656^{* *}$ & $\mathrm{IHO}$ & -61.60001 & 10.68333 & Carenage Bay & $\mathrm{C}$ \\
\hline 657 & $\mathrm{IHO}$ & -61.64999 & 10.66667 & Gaspar Grande & $\mathrm{C}$ \\
\hline $658^{*}$ & $\mathrm{IHO}$ & -61.51692 & 10.64955 & Port of Spain & $\mathrm{C}$ \\
\hline 659 & $\mathrm{IHO}$ & -66.93335 & 10.61667 & La Guaira & $\mathrm{C}$ \\
\hline 660 & $\mathrm{IHO}$ & -62.08334 & 10.61667 & Puerto de Hierro & $\mathrm{C}$ \\
\hline 661 & $\mathrm{IHO}$ & -64.20470 & 10.45000 & Cumana & $\mathrm{C}$ \\
\hline 662 & $\mathrm{IHO}$ & -61.01932 & 10.40000 & Nariva River & $\mathrm{A}$ \\
\hline 663 & $\mathrm{IHO}$ & -75.57640 & 10.38333 & Cartagena & $\mathrm{C}$ \\
\hline 664 & $\mathrm{IHO}$ & -61.48334 & 10.36667 & Point Lisas & $\mathrm{C}$ \\
\hline 665 & $\mathrm{IHO}$ & -61.70001 & 10.18333 & Point Fortin & $\mathrm{C}$ \\
\hline $666^{* *}$ & $\mathrm{IHO}$ & -62.64310 & 10.12410 & Punta Gorda & $\mathrm{C}$ \\
\hline $667^{*}$ & $\mathrm{IHO}$ & -61.01666 & 10.15000 & Guayaguayare Bay & $\mathrm{A}$ \\
\hline $668^{*}$ & $\mathrm{IHO}$ & -61.64999 & 10.06667 & Erin Bay & $\mathrm{C}$ \\
\hline 669 & $\mathrm{IHO}$ & -62.20001 & 10.01667 & Rio Pedernales & $\mathrm{C}$ \\
\hline 670 & $\mathrm{IHO}$ & -83.03333 & 10.00267 & Puerto Limon & $\mathrm{C}$ \\
\hline 671 & $\mathrm{IHO}$ & -79.91666 & 9.36667 & Colon & $\mathrm{C}$ \\
\hline 672 & $\mathrm{IHO}$ & -79.91666 & 9.35000 & Cristobal (Canal Zone) & $\mathrm{C}$ \\
\hline $673 * *$ & $\mathrm{IHO}$ & -59.79999 & 8.41667 & Waini Point & $\mathrm{A}$ \\
\hline $674^{* *}$ & $\mathrm{IHO}$ & -58.25000 & 6.95000 & Bluejacket Beacon & $\mathrm{A}$ \\
\hline $675^{* *}$ & $\mathrm{IHO}$ & -58.04999 & 6.95000 & Demerara Beacon & A \\
\hline $676^{* *}$ & $\mathrm{IHO}$ & -58.41666 & 6.86667 & Parika & $\mathrm{A}$ \\
\hline $677^{*}$ & $\mathrm{IHO}$ & -58.16666 & 6.83333 & Georgetown & A \\
\hline $678^{* *}$ & $\mathrm{IHO}$ & -57.95001 & 6.78333 & Belfield & $\mathrm{A}$ \\
\hline $679 * *$ & $\mathrm{IHO}$ & -58.61667 & 6.40000 & Bartica & $\mathrm{A}$ \\
\hline $680 *$ & $\mathrm{IHO}$ & -57.01666 & 5.96667 & Nickerie River Mouth & A \\
\hline $681^{* *}$ & $\mathrm{IHO}$ & -55.21667 & 5.98630 & Surinam River Entrance Light & A \\
\hline
\end{tabular}

* Station is approximated by nearest neighbor for harmonic extraction since it is not within the actual bounds of the EC2001 model domain but is near the edge of the domain; ** Station is not included in EC2001 error measures or scatter plots as it is not physically within the EC2001 model domain and is far removed from the domain. 


\section{Appendix B}

Scatter plots for the 10 stations shown by a black $X$ in Figures 5 and 6 are provided herein. Both the EC2015 Manning's $n$ and VDatum friction models are compared to the EC2001 model. Note that other than the Pilottown, LA station (313) and Curacoa, Willemstad (645) stations, the different friction formulations generally create more of a difference in the amplitude response than they do in the phase response. Plots are grouped according to region.
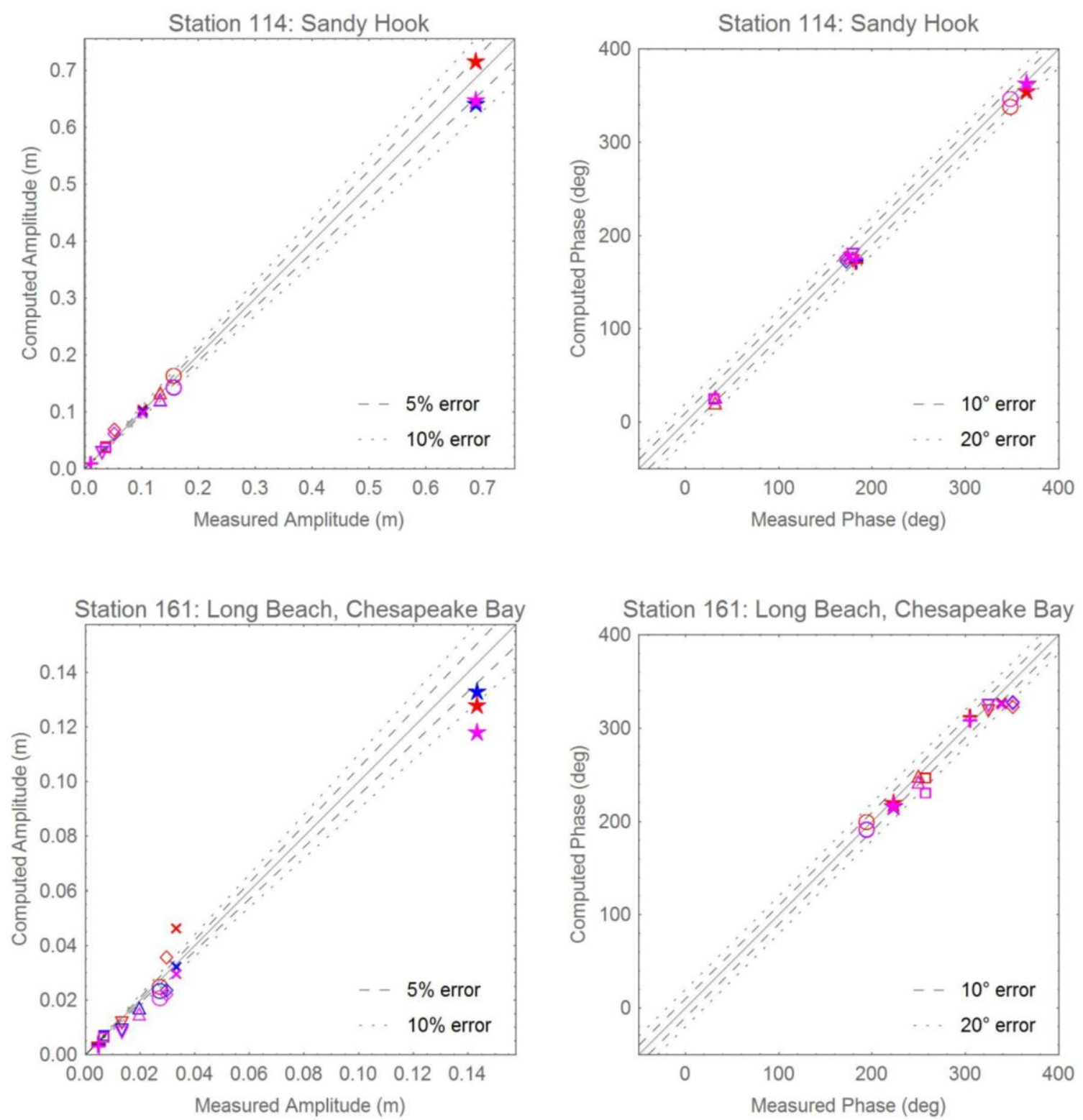

$\diamond \mathrm{O}_{1} \times \mathrm{K} 1 \quad \nabla \mathrm{P} 1+\mathrm{Q} 1 \star \mathrm{M} 2 \Delta \mathrm{S} 2 \quad \mathrm{~N} 2 \quad \mathrm{~K} 2$

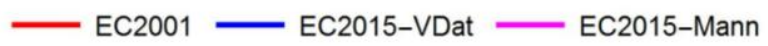

Figure B1. Scatterplots of computed versus measured harmonic data for representative stations along the Atlantic coast. 

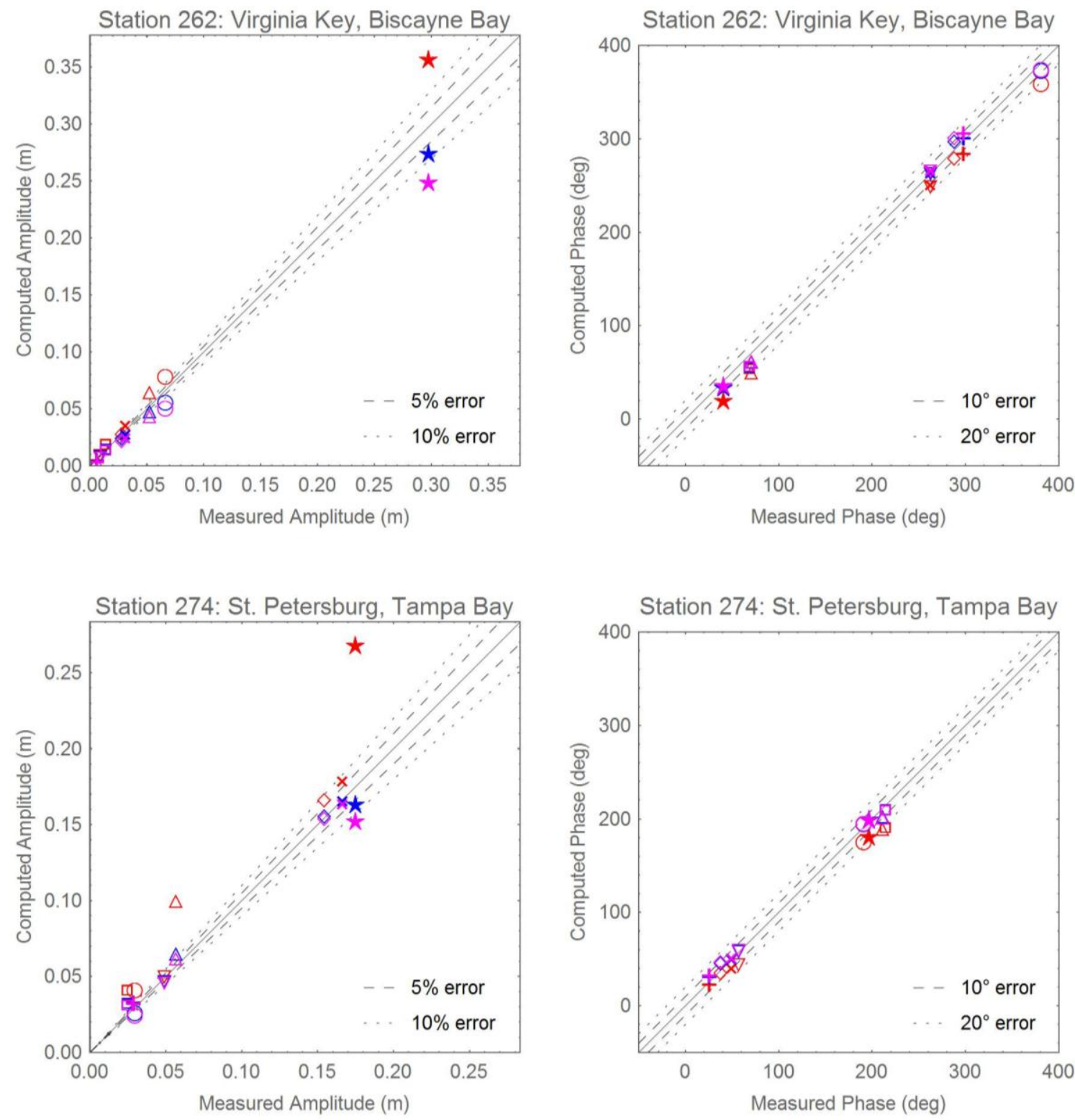

$\diamond \mathrm{O} 1 \times \mathrm{K} 1 \nabla \mathrm{P} 1+\mathrm{Q} 1 \star \mathrm{M} 2 \Delta \mathrm{S} 2 \quad \mathrm{~N} 2 \quad \square \quad \mathrm{K} 2$

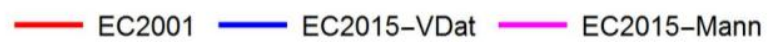

Figure B2. Scatterplots of computed versus measured harmonic data for representative stations along the Florida coast. 

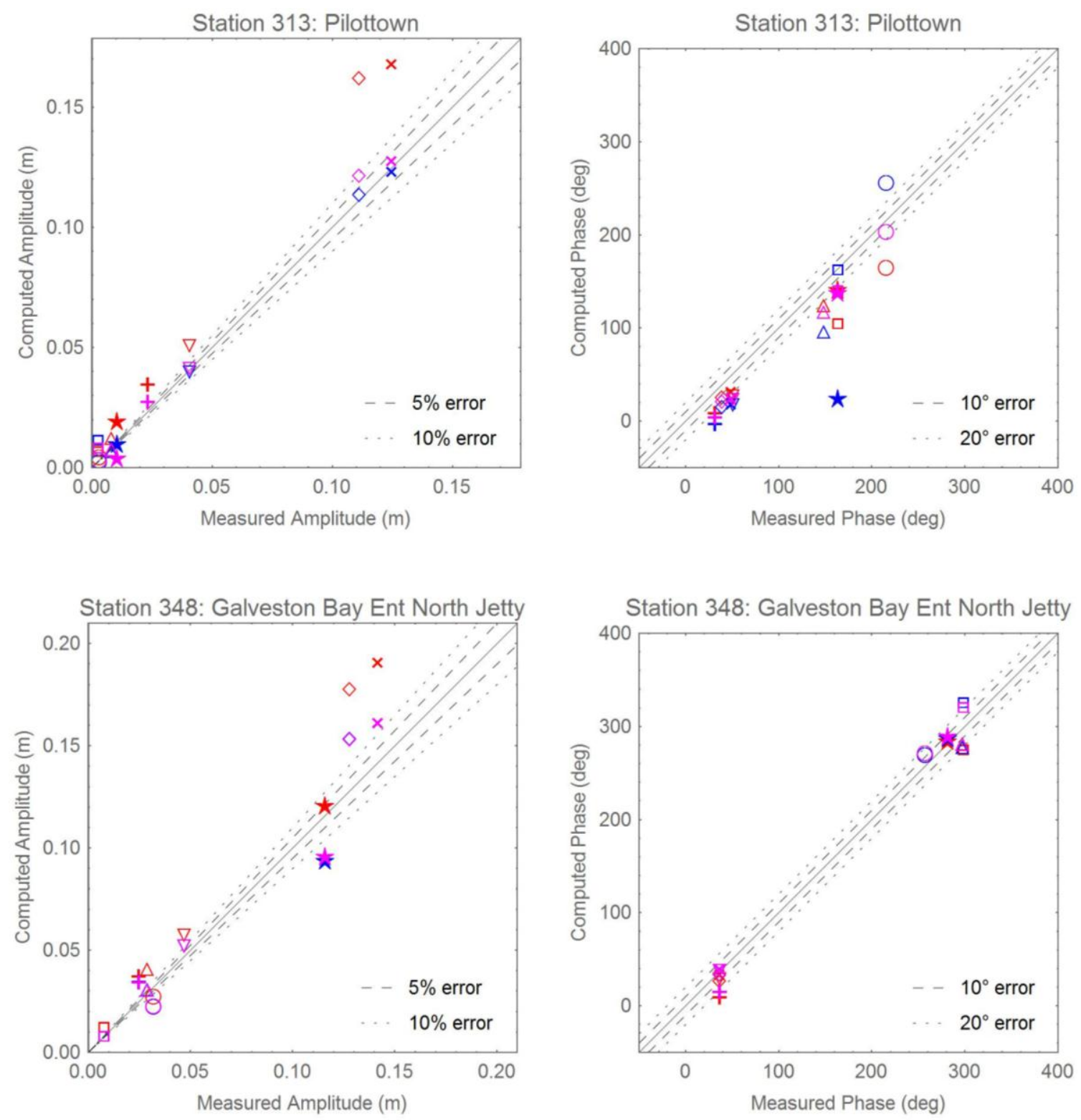

$\diamond \mathrm{O}_{1} \times \mathrm{K} 1 \quad \nabla \mathrm{P} 1+\mathrm{Q} 1 \star \mathrm{M} 2 \Delta \mathrm{S} 2 \quad \mathrm{~N} 2 \quad \square \quad \mathrm{K} 2$

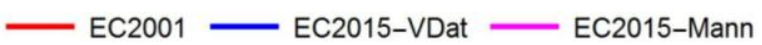

Figure B3. Scatterplots of computed versus measured harmonic data for representative stations along the Gulf of Mexico coast. 

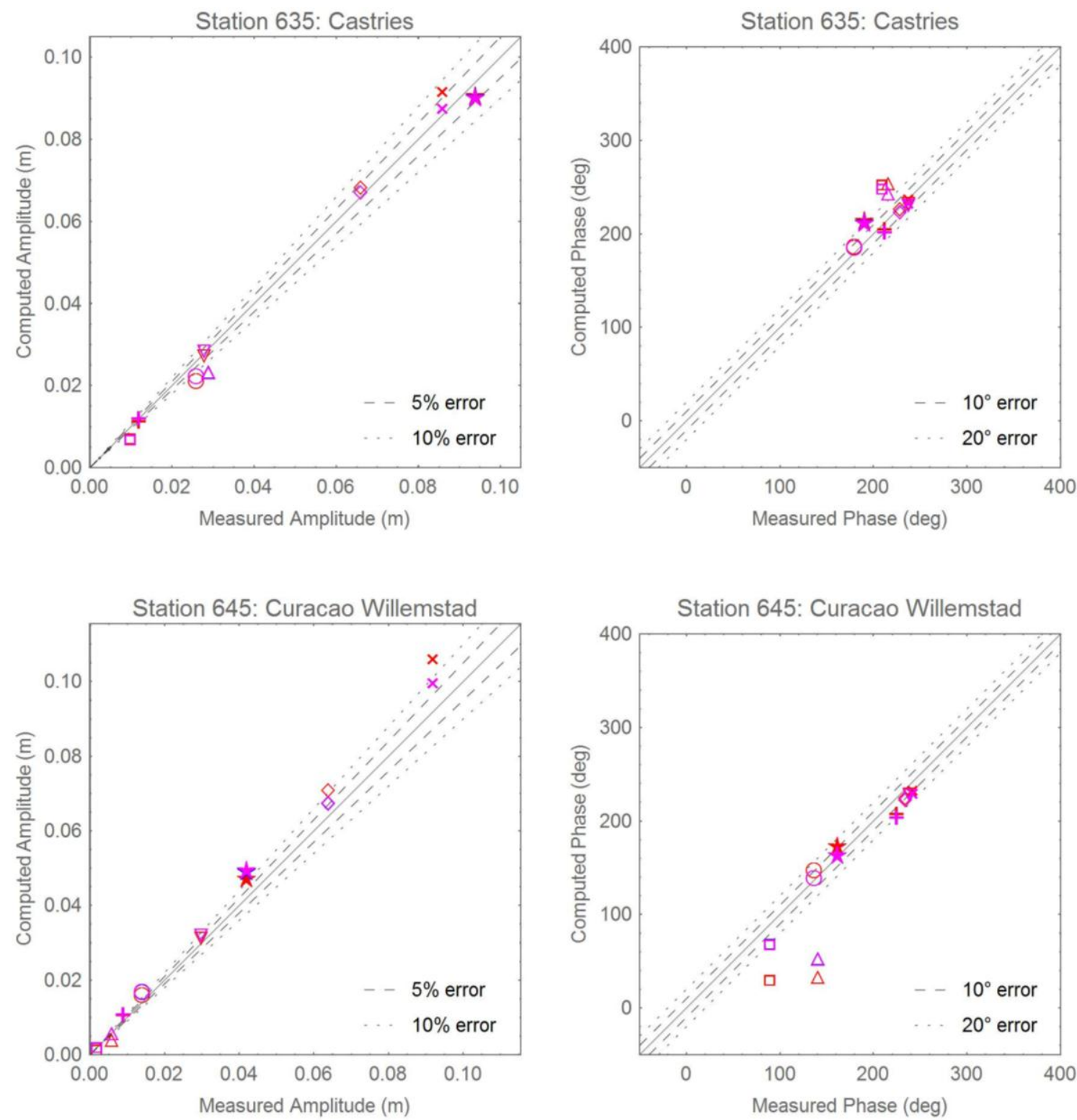

$\diamond \mathrm{O} 1 \times \mathrm{K} 1 \nabla \mathrm{P} 1+\mathrm{Q} 1 \star \mathrm{M} 2 \Delta \mathrm{S} 2 \quad \mathrm{~N} 2 \quad \square \quad \mathrm{K} 2$

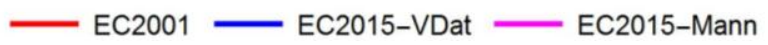

Figure B4. Scatterplots of computed versus measured harmonic data for representative stations in the Caribbean Sea. 

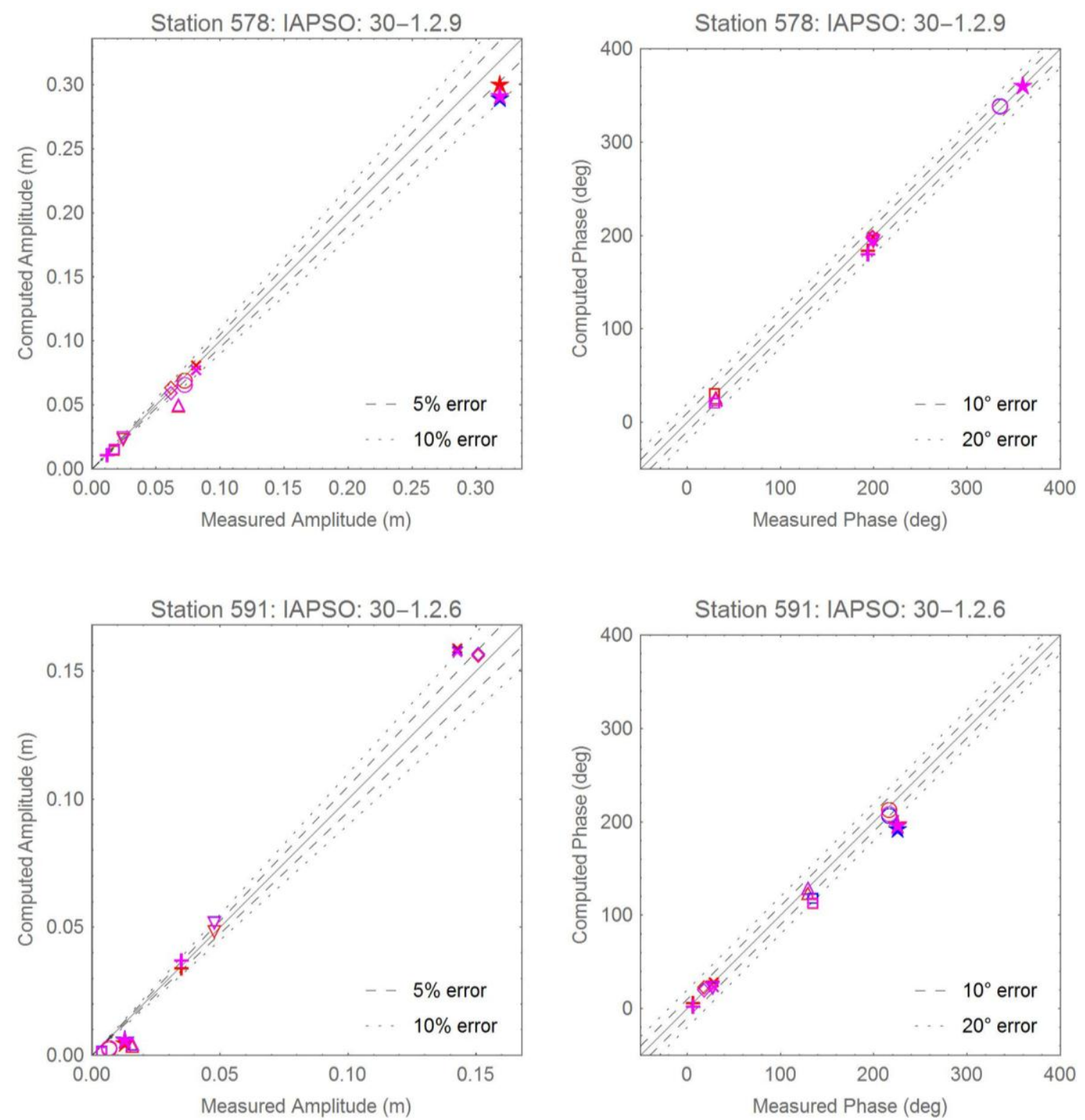

$\diamond \mathrm{O} 1 \times \mathrm{K} 1 \quad \nabla \mathrm{P} 1+\mathrm{Q} 1 \quad$ M2 $\Delta \mathrm{S} 2 \quad \mathrm{O} 2 \quad \mathrm{~N} 2 \mathrm{~K} 2$

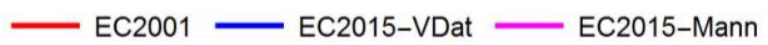

Figure B5. Scatterplots of computed versus measured harmonic data for representative deep IHO stations.

\section{Appendix C}

The actual geographic distribution of errors for the $\mathrm{K}_{1}$ and $\mathrm{M}_{2}$ constituents are provided at all 681 validation stations in the following seven figures. Although the same regional views given in Figures 5 and 6 are used herein, only the dominant constituent is shown in each subregion: Gulf of Maine, Atlantic Coast and Florida Coast- $\mathrm{M}_{2}$, Gulf of Mexico and Caribbean Sea- $\mathrm{K}_{1}$. Symbol shapes denote the magnitude of the errors while the colors represent whether the EC2015 model is over (red) 
or underestimating (blue) the amplitudes. Similarly, blue symbols denote locations where the model exhibits a phase lag while red symbols denote a phase lead.

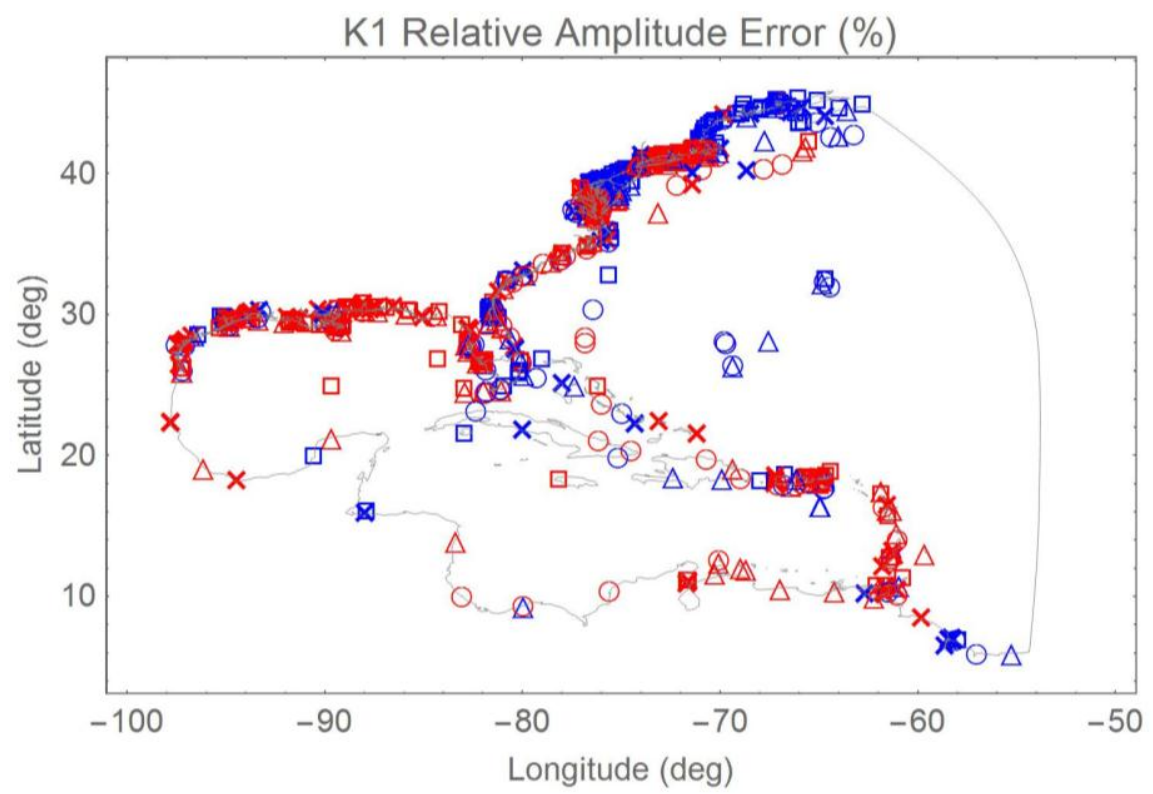

$\times$ e $<-20 \%$

ㅁ $-20 \leq \mathrm{e}<-10 \%$

$\Delta-10 \leq e<-5 \%$

$-5 \leq \mathrm{e}<0 \%$

$0<\mathrm{e} \leq 5 \%$

$\triangle 5<\mathrm{e} \leq 10 \%$

ㅁ $10<\mathrm{e} \leq 20 \%$

$\times 20 \%<\mathrm{e}$

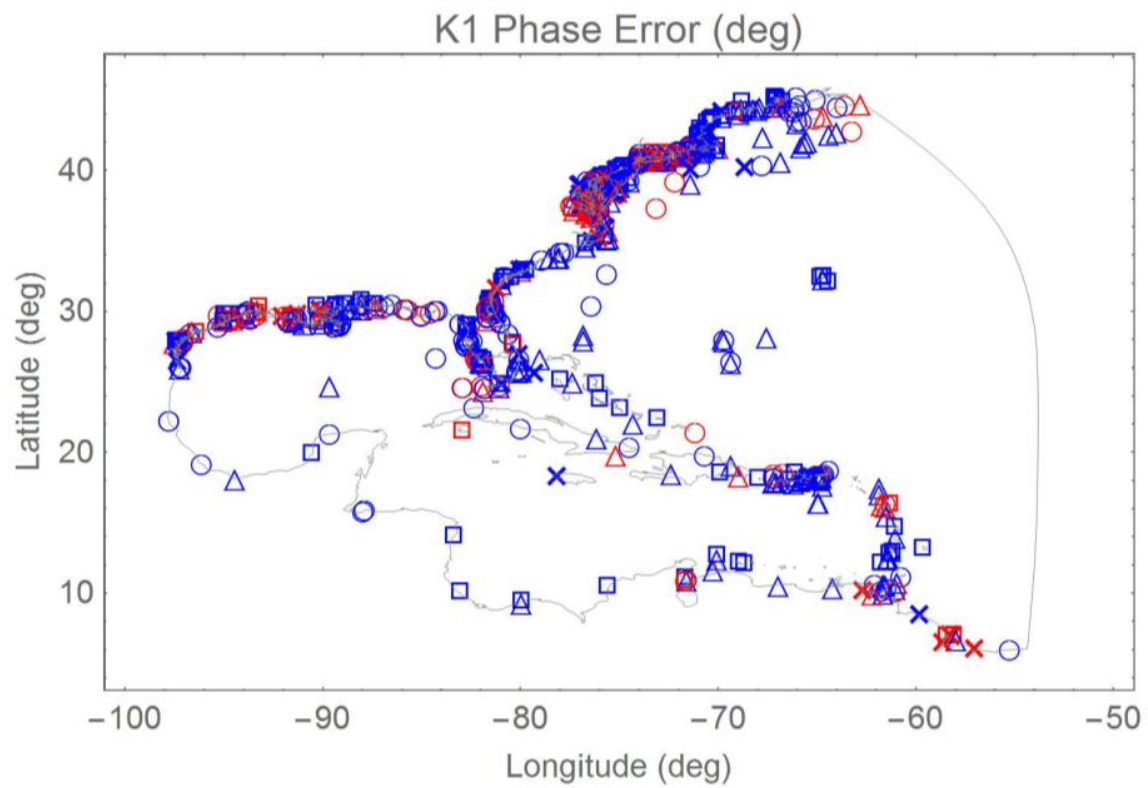

$x \quad e<-20^{\circ}$

ㅁ $-20^{\circ} \leq \mathrm{e}<-10^{\circ}$

$\Delta-10^{\circ} \leq \mathrm{e}<-5^{\circ}$

$-5^{\circ} \leq \mathrm{e}<0^{\circ}$

$0^{\circ}<\mathrm{e} \leq 5^{\circ}$

$\triangle 5^{\circ}<\mathrm{e} \leq 10^{\circ}$

ㅁ $10^{\circ}<\mathrm{e} \leq 20^{\circ}$

$\times 20^{\circ}<\mathrm{e}$

Figure C1. Distribution of relative amplitude and absolute phase errors for the $\mathrm{K}_{1}$ constituent: global view. 

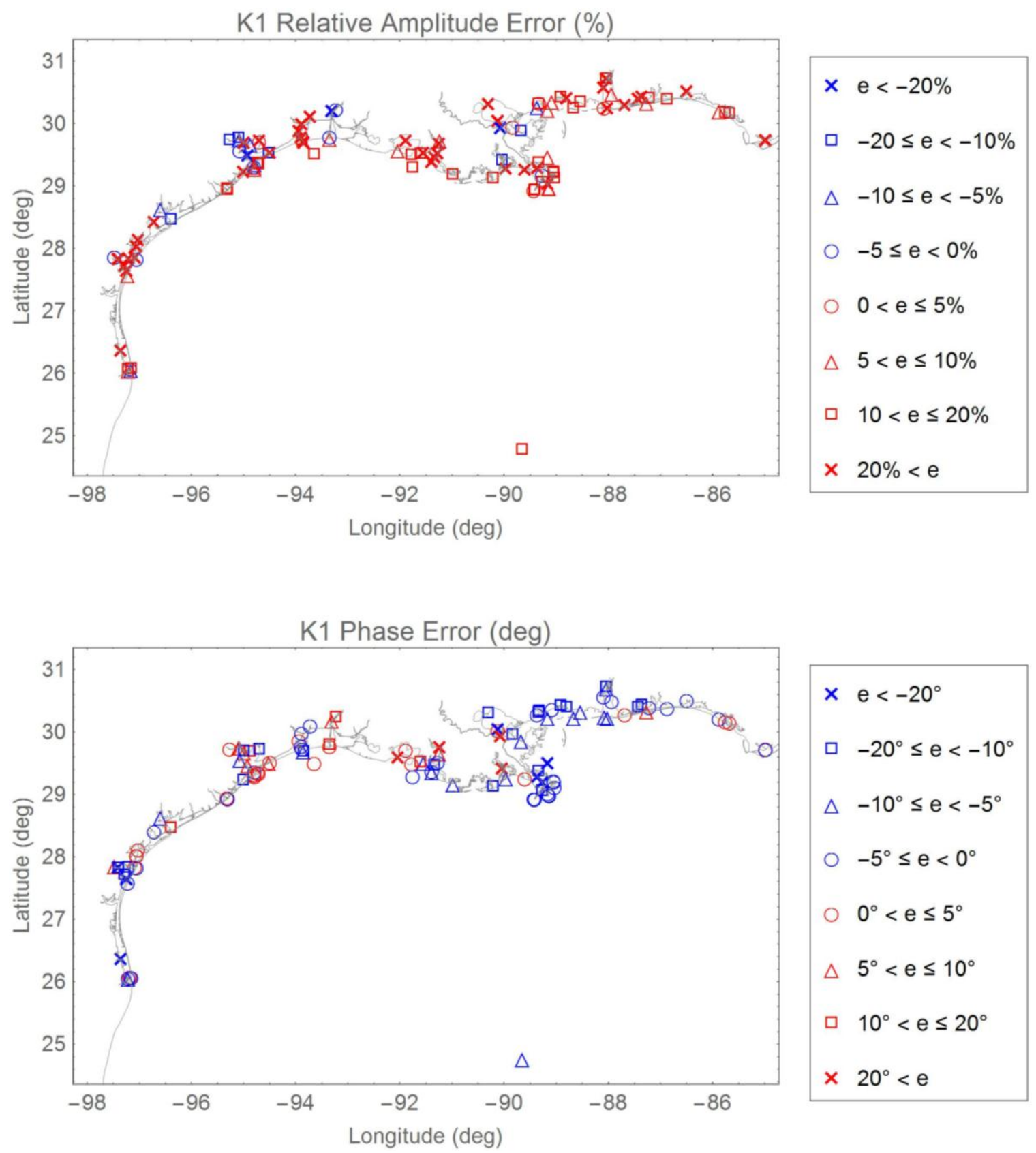

Figure C2. Distribution of relative amplitude and absolute phase errors for the $\mathrm{K}_{1}$ constituent: Gulf of Mexico. 


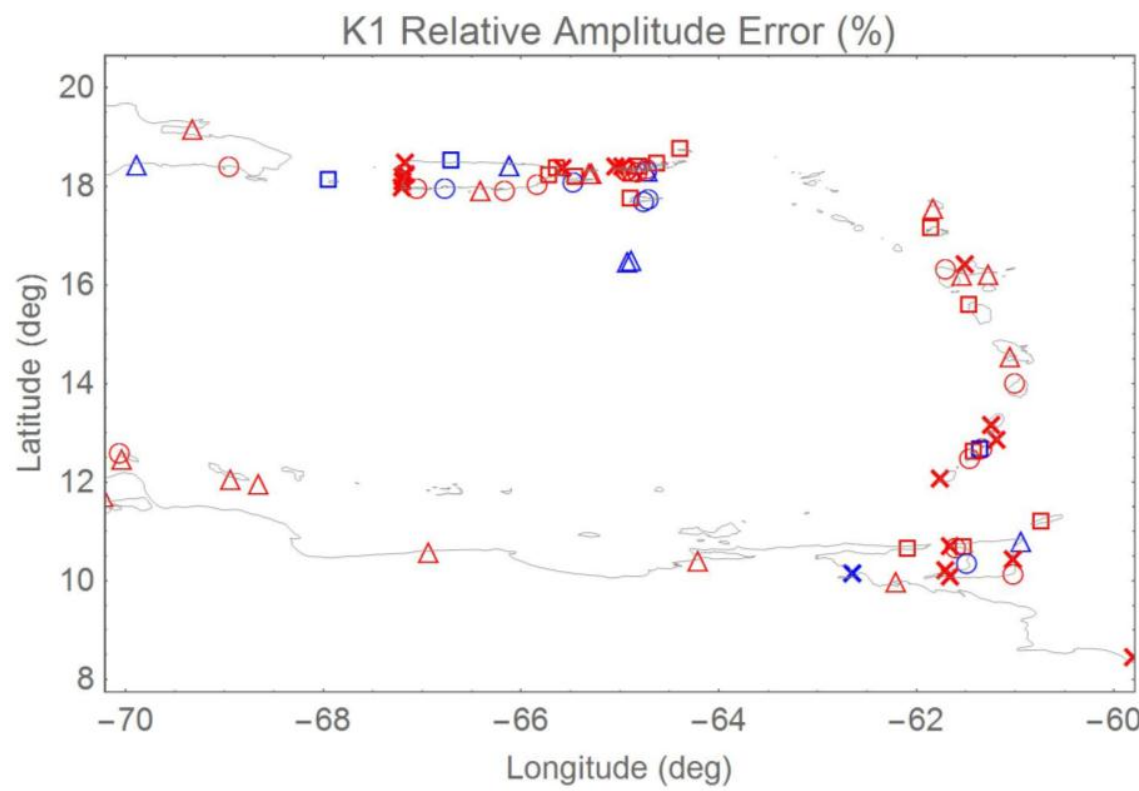

$x \quad e<-20 \%$

ㅁ $-20 \leq \mathrm{e}<-10 \%$

$\Delta-10 \leq e<-5 \%$

$-5 \leq \mathrm{e}<0 \%$

$0<e \leq 5 \%$

$\triangle 5<\mathrm{e} \leq 10 \%$

ㅁ $10<\mathrm{e} \leq 20 \%$

$\times 20 \%<\mathrm{e}$

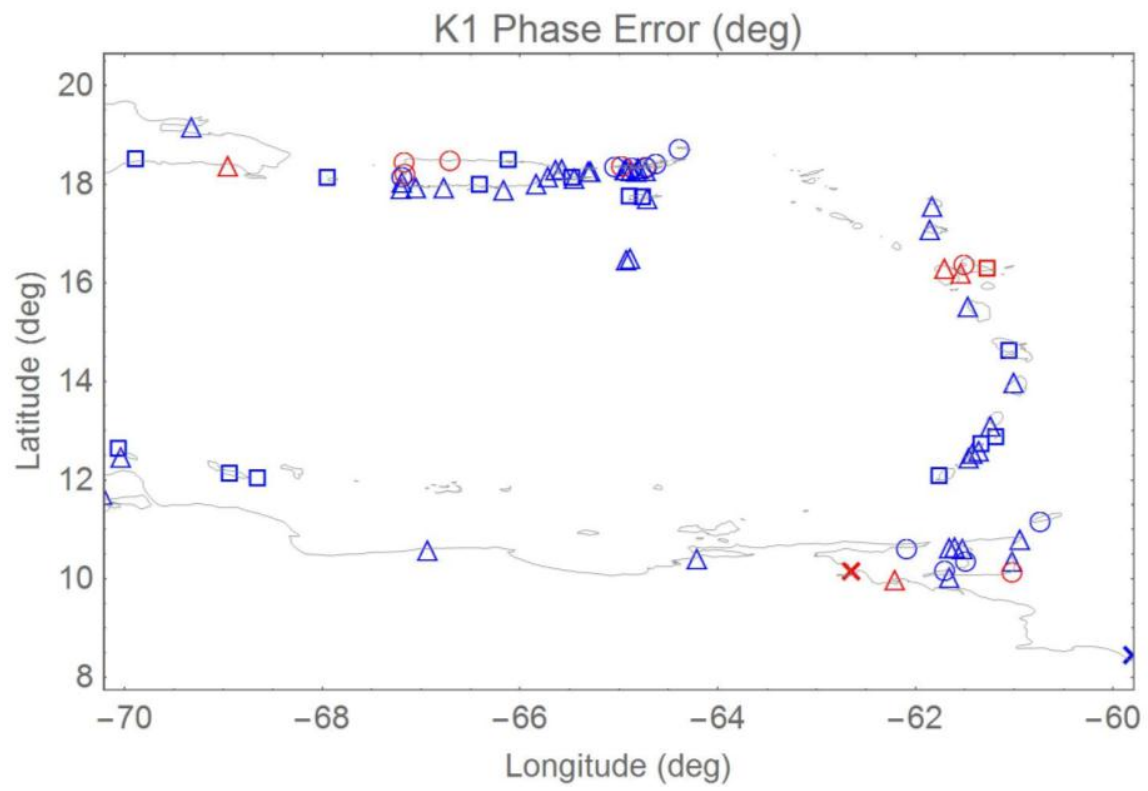

$x$ e $<-20^{\circ}$

ㅁ $-20^{\circ} \leq \mathrm{e}<-10^{\circ}$

$\Delta-10^{\circ} \leq \mathrm{e}<-5^{\circ}$

$-5^{\circ} \leq \mathrm{e}<0^{\circ}$

$0^{\circ}<\mathrm{e} \leq 5^{\circ}$

$\triangle 5^{\circ}<\mathrm{e} \leq 10^{\circ}$

ㅁ $10^{\circ}<\mathrm{e} \leq 20^{\circ}$

$\times 20^{\circ}<e$

Figure C3. Distribution of relative amplitude and absolute phase errors for the $\mathrm{K}_{1}$ constituent: Caribbean Sea. 

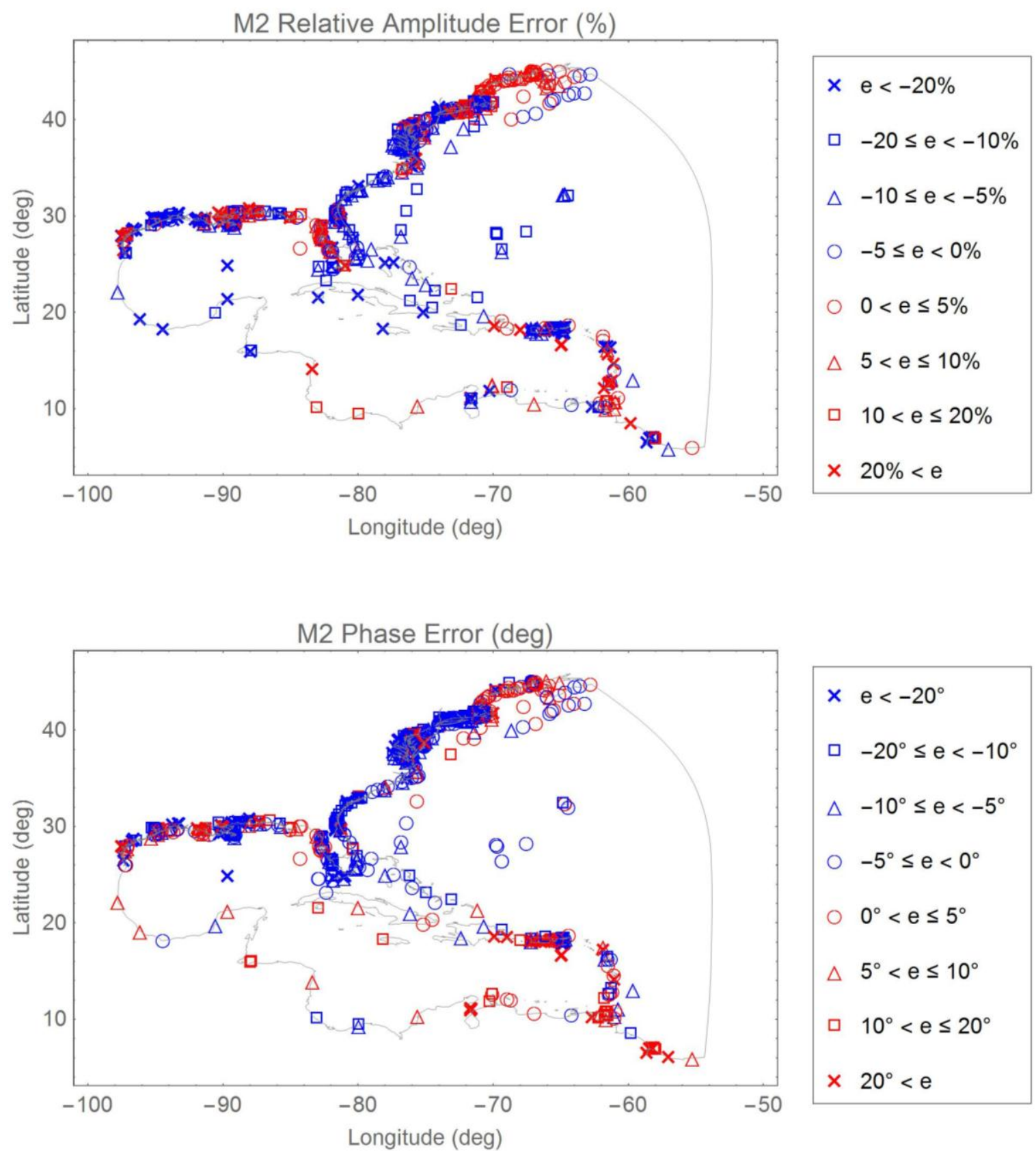

$x \quad e<-20^{\circ}$

ㅁ $-20^{\circ} \leq \mathrm{e}<-10^{\circ}$

$\Delta-10^{\circ} \leq e<-5^{\circ}$

$-5^{\circ} \leq \mathrm{e}<0^{\circ}$

ㅇ $0^{\circ}<\mathrm{e} \leq 5^{\circ}$

$\triangle 5^{\circ}<\mathrm{e} \leq 10^{\circ}$

ㅁ $10^{\circ}<\mathrm{e} \leq 20^{\circ}$

$\times 20^{\circ}<\mathrm{e}$

Figure C4. Distribution of relative amplitude and absolute phase errors for the $\mathrm{M}_{2}$ constituent: global view. 

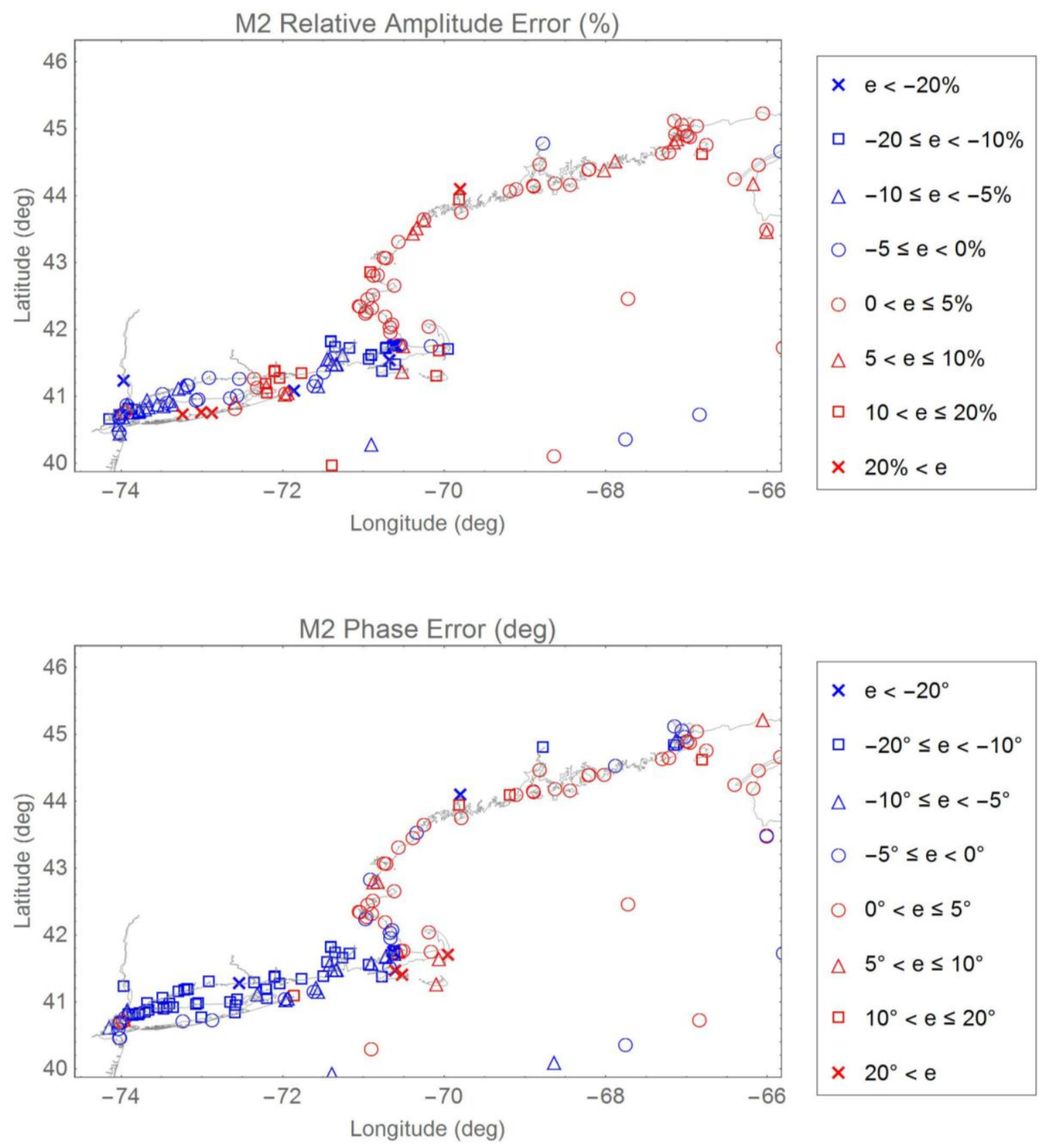

Figure C5. Distribution of relative amplitude and absolute phase errors for the $\mathrm{M}_{2}$ constituent: Gulf of Maine and New York Bight. 

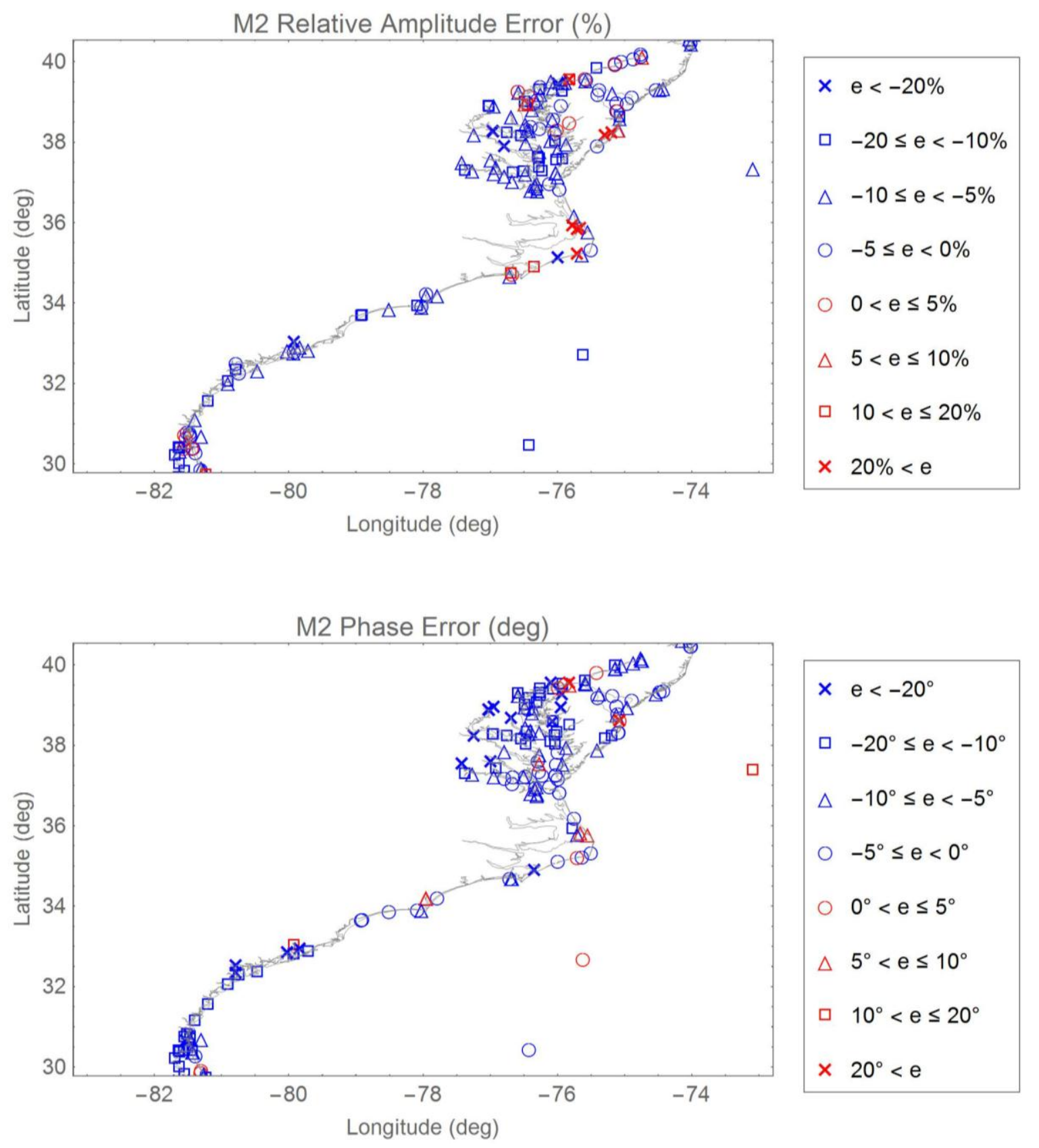

Figure C6. Distribution of relative amplitude and absolute phase errors for the $\mathrm{M}_{2}$ constituent: Atlantic coast from Delaware to Georgia. 

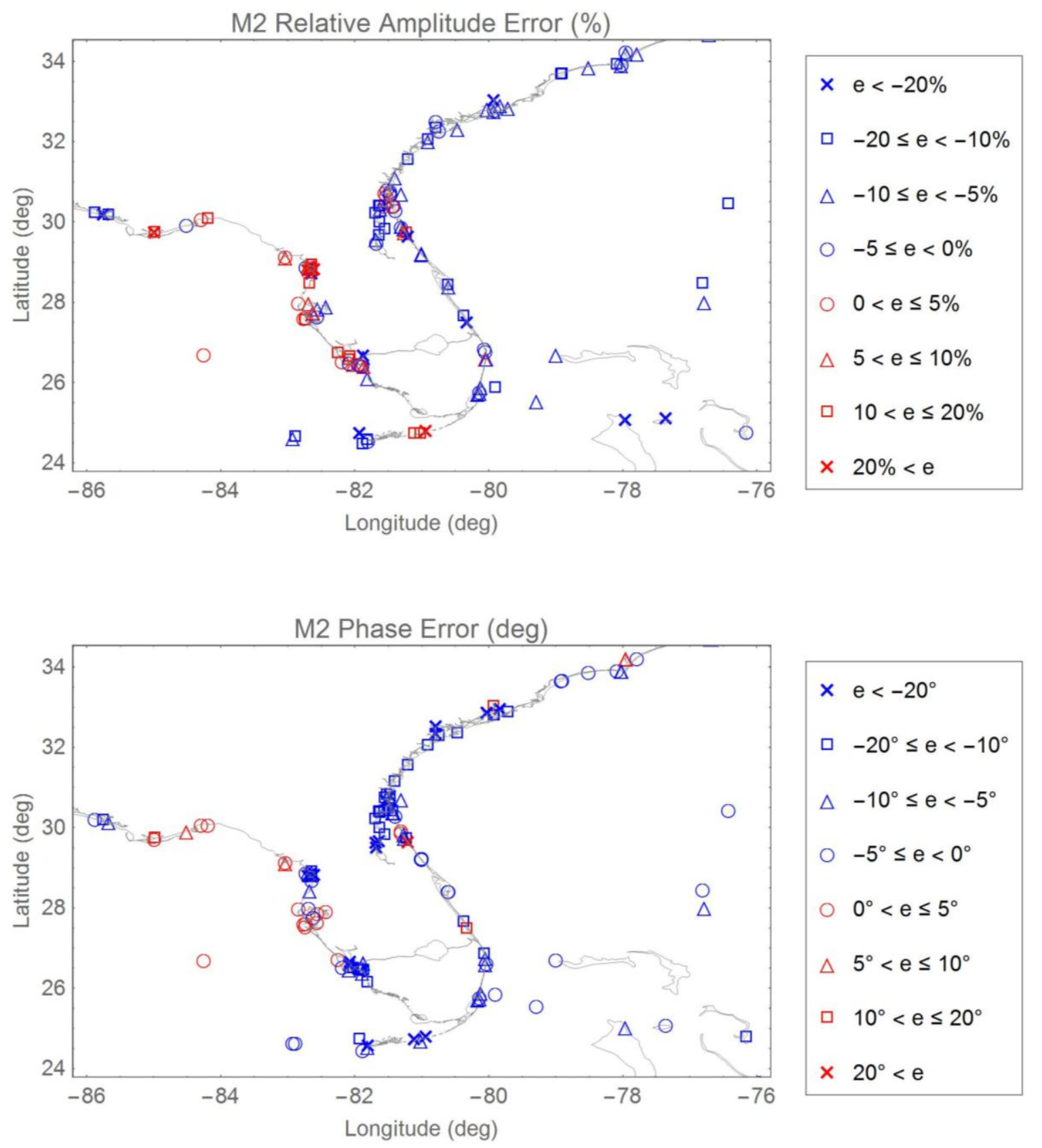

Figure C7. Distribution of relative amplitude and absolute phase errors for the $\mathrm{M}_{2}$ constituent: Florida coast.

\section{Appendix D}

Herein we provide general applicability and usage guidelines for the EC205 tidal database. It is recommended that users read through these sections to understand the limitations of the database before they apply it to their own regions of interest.

Appendix D.1. Applicability Guidelines for the EC2015 Tidal Database

The EC2015 tidal database provides elevation amplitudes and phases throughout the WNAT domain for all 37 constituents frequently used by NOS. Although data for all 37 constituents are included in the database, care should be taken when deciding how many of these constituents are important for the user's intended application. Often, accurate results can be obtained when using only 
the primary astronomic tides, particularly if the boundary of interest is in deeper water, far removed from the coastline.

This database does not provide information regarding responses associated with density effects, riverine driven circulation, wind and atmospheric pressure driven events and/or oceanic currents. Vertical and horizontal variations in density can set up steric level differences in sea surface elevation, can drive significant horizontal circulation patterns, and can cause variation in the vertical structure of the currents. These effects tend to be important in estuarine or delta systems with significant freshwater riverine inflows. Furthermore the seasonal heating of the upper layers of the ocean's surface directly drives the expansion in the upper layer water volume that is associated with a seasonal fluctuation of water level. This can be especially significant in the Gulf of Mexico and the Caribbean Sea. It is noted that published tidal constituent data includes these seasonal sea surface expansions as long-term tidal constituents such as the Sa Solar annual and the Ssa Solar semiannual constituents. From a tidal hydrodynamics perspective these long-term constituents (with periods of a year and half a year respectively) are of astronomical origin and should appear as weak tides. They may also be generated through nonlinear interactions that lead to extremely weak responses. Nonetheless, in harmonically-decomposed measured field data, these constituents can appear as significant constituents since the driving radiational heating process is also an annual event. In the Gulf of Mexico, the Sa and Ssa elevation constituents can be almost as large as the dominant diurnal tides while current responses are much smaller due to the long-term period associated with these constituents. Thus it is emphasized that the EC2015 computations are entirely barotropic and do not include any of these density effects.

Rivers were not included in the EC2015 tidal database calculations. The barotropic pressure gradient and mass input effects of the river will be important in the immediate vicinity of the river outlet and will diminish away from the river outlet. Wind driven and/or atmospheric pressure driven effects such as coastal setup and storm surge and any basinwide modes that may be set up by these processes are also not included in the database. These effects can be significant on the shelf as well as within bays and estuaries. Major oceanic circulation patterns such as the Gulf Stream and the associated loop currents and other eddies, which are shed from it, are not included in the database. These currents tend to reside off the shelf in deep ocean waters but can be associated with fast flows in the 1 to $2 \mathrm{~m} / \mathrm{s}$ range.

Finally the local accuracy of the EC2015 tidal computations will be affected by the accuracy of the geometry and bathymetry locally defined in the WNAT-based EC2015 grid. Geometric and bathymetric inaccuracies in the grid will especially affect the accuracy of the currents. Obviously a missing estuary or island or inaccurate bathymetry will greatly influence the database computations.

\section{Appendix D.2. Usage Guidelines for the EC2015 Tidal Database}

The EC2015 tidal constituent database can be applied anywhere within the defined WNAT domain. However, the prevailing hydrodynamics in a specific region will determine how accurately the currents will be predicted. If the surface elevation response and currents are indeed dominated by astronomical tides, then the database will provide an excellent prediction of the response. A good estimate of the accuracy of the EC2015 tides can be obtained by examining the regional error estimates given in Tables 7 and 8, or by examining the error plots provided for the dominant constituents in Appendix $C$; although plots are only provided for the $\mathrm{M}_{2}$ and $\mathrm{K}_{1}$ constituents, in general, all four of the semi-diurnal constituents follow the same regional trends, as do the diurnal constituents. Furthermore how accurately the EC2015 grid and bathymetry describe the region of specific interest influences the accuracy and appropriateness of applying database values.

For locations that are tidally dominated and for which the EC2015 grid accurately describes both local geometry and bathymetry, the database can be directly applied to extract tidal elevations and currents. Because the thirty-seven constituents are computed at every node and are defined within the 
framework of a finite element grid, values at any point within the domain can be readily interpolated from the nodal values within which the point lies.

An extraction program, ADCIRC_db_extract.F90, together with the EC2015 finite element grid file, ec2012_v3d_chk.grd, accompany the tidal database. The user must supply an input file that provides the number of extraction points desired followed by the list of coordinates for those points. The extraction program will prompt the user for this input files as well as the name of the grid used to create the database. The program will also prompt the user whether they would like to produce the harmonic constituent output for elevations, velocities or both and then will produce the harmonic extraction output for amplitude and phase at the specified location(s) according to the user's request. Elevation output is stored in elev_hc.out while velocity output is stored in vel_hc.out. Additionally, diagnostic output is written to tides.dia and provides the location of each extraction point in the global mesh as well as the interpolation weights used to calculate the harmonic constituents. The KDTREE2 search algorithms have been incorporated into the new extraction program to facilitate a speedier search response. Finally, the program takes advantage of dynamic allocation in order to avoid the old hardcoded array limitations found in previous extraction routines. The ADCIRC_db_extract.F90 program will work with any old ADCIRC databases that utilized the individual fort.53 and fort.54 file formats.

A time-history of response can be readily Fourier synthesized using the outputs in the elev_hc.out and vel_hc.out files. For example a time-history of water-surface elevation can be computed as

$$
\zeta(x, y, t)=\sum A_{i}(x, y) f_{i}\left(t_{0}\right) \cos \left[\sigma_{i}\left(t-t_{0}\right)+V_{i}\left(t_{0}\right)-h_{i}(x, y)\right]
$$

where $\mathrm{A}_{i}(x, y)$ and $\mathrm{h}_{i}(x, y)$ are the amplitude and phase, respectively, at the location $(x, y)$ of interest for constituent $i$, which are provided by the EC2015 tidal database, and the frequency $\sigma_{i}=2 \pi / T_{i}$. The frequencies $\sigma_{i}$ in rad/sec and periods $T_{i}$ in hours for each of the 37 constituents included in the database are presented in Table D1. It is important to specify frequencies precisely, at least to eight significant figures. The nodal factor $f_{i}\left(t_{0}\right)$ and the equilibrium argument, $V_{i}\left(t_{0}\right)$, relative to reference time $t_{0}$ can be computed using program tide_fac.f, which is available as a utility program on the ADCIRC website [60].

Table D1. Frequencies and periods for EC2015 harmonic constituents.

\begin{tabular}{ccc}
\hline Constituent & Frequency (Rad/s) & Period (h) \\
\hline $\mathrm{M}(2)$ & 0.0001405189 & 12.42 \\
$\mathrm{~N}(2)$ & 0.0001378797 & 12.66 \\
$\mathrm{~S}(2)$ & 0.0001454441 & 12.00 \\
$\mathrm{O}(1)$ & 0.0000675977 & 25.82 \\
$\mathrm{~K}(1)$ & 0.0000729212 & 23.93 \\
$\mathrm{~K}(2)$ & 0.0001458423 & 11.97 \\
$\mathrm{~L}(2)$ & 0.0001431581 & 12.19 \\
$2 \mathrm{~N}(2)$ & 0.0001352405 & 12.91 \\
$\mathrm{R}(2)$ & 0.0001456432 & 11.98 \\
$\mathrm{~T}(2)$ & 0.0001452450 & 12.02 \\
$\mathrm{Lambda}(2)$ & 0.0001428049 & 12.22 \\
$\mathrm{Mu}(2)$ & 0.0001355937 & 12.87 \\
$\mathrm{Nu}(2)$ & 0.0001382329 & 12.63 \\
$\mathrm{~J}(1)$ & 0.0000755604 & 23.10 \\
$\mathrm{M}(1)$ & 0.0000702820 & 24.83 \\
$\mathrm{OO}(1)$ & 0.0000782446 & 22.31 \\
$\mathrm{P}(1)$ & 0.0000725229 & 24.07 \\
$\mathrm{Q}(1)$ & 0.0000649585 & 26.87 \\
\hline
\end{tabular}


Table D1. Cont.

\begin{tabular}{ccc}
\hline Constituent & Frequency (Rad/s) & Period (h) \\
\hline QQ(1) & 0.0000623193 & 28.01 \\
Rho(1) & 0.0000653117 & 26.72 \\
M(4) & 0.0002810378 & 6.21 \\
M(6) & 0.0004215567 & 4.14 \\
M(8) & 0.0005620756 & 3.11 \\
S(4) & 0.0002908882 & 6.00 \\
S(6) & 0.0004363323 & 4.00 \\
M(3) & 0.0002107784 & 8.28 \\
S(1) & 0.0000727221 & 24.00 \\
MK(3) & 0.0002134401 & 8.18 \\
$2 \mathrm{MK}(3)$ & 0.0002081166 & 8.39 \\
MN(4) & 0.0002783986 & 6.27 \\
MS(4) & 0.0002859630 & 6.10 \\
SM(2) & 0.0001503693 & 11.61 \\
Mf & 0.0000053234 & 327.86 \\
Msf & 0.0000049252 & 354.37 \\
Mm & 0.0000026392 & 661.31 \\
Sa & 0.0000001991 & 8765.82 \\
Ssa & 0.0000003982 & 4382.91 \\
\hline
\end{tabular}

In locations and/or at times where the hydrodynamics is not tidally dominated and/or the EC2015 grid does not provide sufficient geometric and/or bathymetric detail, a regional model that interfaces with the EC2015 model will lead to a better representation of regional flows. Some examples of cases where this may be appropriate include: (a) bays or estuaries not included in the grid; (b) shallow nonlinearly-dominated inlets or estuaries; (c) coastal and/or estuarine regions barotropically and/or baroclinically influenced by a significant riverine discharge; (d) combined wind- and tidally-driven circulation on a shelf. The basic idea is to construct a domain/grid that extends onto or beyond the shelf within the EC2015 domain. The open ocean boundary is then forced using the tidal constituent data from the EC2015 tidal data base. The defined domain may also include additional regional detail in geometric and bathymetric definition, may include additional forcing functions on select boundaries or within the domain, and/or may include additional terms in the governing equations.

The regional model open ocean boundary should be placed away from the region of immediate interest, and its exact position and shape depends on the application. In no case should the boundary be placed at the mouth or entrance to an embayment of interest. The tidal constituents on the open ocean boundary nodes of the regional model are extracted in the same way as a simple point location. It may be necessary to add an additional forcing component to the boundary elevation and/or radiation forcing function to account for additional interior domain processes and forces. In the development of a regional model it is also recommended that the bathymetry along the open boundary match the bathymetry of the EC2015 grid. This will help ensure that the boundary condition extracted from the EC2015 database is physically consistent with the regional model. Failure to match bathymetries along the regional model open boundary can lead to unrealistic gyre formation and/or instabilities in the regional model computations. The bathymetry can depart from that comprising the EC2015 grid away from the open boundary area.

The EC2015 tidal database is available on the ADCIRC website as two separate compressed files: EC2015_elev-only_tidaldatabase.tar, which contains all of the extraction programs, grids, and sample notes but only has the fort.53 elevation harmonics; and EC2015_tidaldatabase.tar, which has everything given in the previous file with the addition of the fort.54 velocity harmonics [24]. You will only need to download one of the files depending upon whether you wish to have access to the velocity data as well. 
In addition to the ADCIRC_db_extract.F90 extraction program, the database also includes another utility for "cutting" a portion of the global database out for visualization within SMS (or other tools). The HarmonicResultScope.f90 program works much the same way as ResultScope.f90, for those who are familiar with that ADCIRC utility program. Additional notes about the usage of each of these programs, as well as sample input and output files for each, are included in the TidalExtract/ directory within the database tar file.

\section{References}

1. Pandoe, W.; Edge, B. Case Study for a Cohesive Sediment Transport Model for Matagorda Bay, Texas, with Coupled ADCIRC 2D-Transport and SWAN Wave Models. J. Hydraul. Eng. 2008, 134, 303-314. [CrossRef]

2. Grzegorzewski, A.S.; Johnson, B.D.; Wamsley, T.V.; Rosati, J.D. Sediment transport and morphology modeling of Ship Island, Mississippi, USA, during storm events. In Proceedings of Coastal Dynamics 2013, Arcachon Convention Centre, Arcachon, France, 24-28 June 2013; pp. 1505-1516.

3. Miles, T.; Seroka, G.; Kohut, J.; Schofield, O.; Glenn, S. Glider observations and modeling of sediment transport in Hurricane Sandy. J. Geophys. Res. Oceans 2015, 120, 1771-1791. [CrossRef]

4. Dietsche, D.; Hagen, S.C.; Bacopoulos, P. Storm Surge Simulations for Hurricane Hugo (1989): On the Significance of Inundation Areas. J. Waterw. Port Coast. Ocean Eng. 2007, 133, 183-191. [CrossRef]

5. Irish, J.L.; Resio, D.T.; Ratcliff, J.J. The influence of storm size on hurricane surge. J. Phys. Oceanogr. 2008, 38, 2003-2013. [CrossRef]

6. Kerr, P.C.; Donahue, A.S.; Westerink, J.J.; Luettich, R.A., Jr.; Zheng, L.Y.; Weisberg, R.H.; Huang, Y.; Wang, H.V.; Teng, Y.; Forrest, D.R.; et al. U.S. IOOS coastal and ocean modeling testbed: Inter-model evaluation of tides, waves, and hurricane surge in the Gulf of Mexico. J. Geophys. Res. Oceans 2013, 118, 5129-5172. [CrossRef]

7. Mattocks, C.; Forbes, C. A real-time, event-triggered storm surge forecasting system for the state of North Carolina. Ocean Model. 2008, 25, 95-119. [CrossRef]

8. Fleming, J.G.; Fulcher, C.W.; Luettich, R.A.; Estrade, B.D.; Allen, G.D.; Winer, S.H. A Real Time Storm Surge Forecasting System Using ADCIRC. In Proceedings of International Conference on Estuarine and Coastal Modeling 2007, Newport, RI, USA, 5-7 November 2007; Spaulding, M.L., Ed.; ASCE: Reston, VA, USA, 2008; pp. 893-912.

9. Dresback, K.M.; Fleming, J.G.; Blanton, B.O.; Kaiser, C.; Gourley, J.J.; Tromble, E.M.; Luettich, R.A., Jr.; Kolar, R.L.; Hong, Y.; van Cooten, S.; et al. Skill Assessment of a Real-Time Forecast System Utilizing a Coupled Hydrologic and Coastal Hydrodynamic Modeling During Hurricane Irene (2011). Cont. Shelf Res. 2013, 71, 78-94. [CrossRef]

10. Dietrich, J.C.; Dawson, C.N.; Proft, J.M.; Howard, M.T.; Wells, G.; Fleming, J.G.; Luettich, R.A., Jr.; Westerink, J.J.; Cobell, Z.; Vitse, M.; et al. Real-Time Forecasting and Visualization of Hurricane Waves and Storm Surge Using SWAN + ADCIRC and FigureGen. Comput. Chall. Geosci. 2013, 156, 49-70.

11. Feyen, J.; Hess, K.; Spargo, E.; Wong, A.; White, S.; Sellars, J.; Gill, S. Development of a continuous bathymetric/topographic unstructured coastal flooding model to study sea level rise in North Carolina. In Proceedings of International Conference on Estuarine and Coastal Modeling 2005, Charleston, SC, USA, 31 October-2 November 2005; Spaulding, M.L., Ed.; ASCE: Reston, VA, USA, 2006; pp. 338-356.

12. Atkinson, J.; McKee Smith, J.; Bender, C. Sea-Level Rise Effects on Storm Surge and Nearshore Waves on the Texas Coast: Influence of Landscape and Storm Characteristics. J. Waterw. Port Coast. Ocean Eng. 2013, 139, 98-117. [CrossRef]

13. Bilskie, M.V.; Hagen, S.C.; Medeiros, S.C.; Passeri, D.L. Dynamics of sea level rise and coastal flooding on a changing landscape. Geophys. Res. Lett. 2014, 41, 927-934. [CrossRef]

14. Cheng, T.K.; Hill, D.F.; Beamer, J.; García-Medina, G. Climate change impacts on wave and surge processes in a Pacific Northwest (USA) estuary. J. Geophys. Res. Oceans 2015, 120, 182-200. [CrossRef]

15. Carr, S.D.; Hench, J.L.; Luettich, R.A.; Forward, R.B.; Tankersley, R.A. Spatial patterns in the ovigerous Callinectes sapidus spawning migration: Results from a coupled behavioral-physical model. Mar. Ecol. Prog. Ser. 2005, 294, 213-226. [CrossRef] 
16. Oliveira, A.; Fortunato, A.B.; Pinto, L. Modeling the hydrodynamics and the fate of passive and active tracers in the Guadiana estuary. Estuar. Coast. Shelf Sci. 2006, 70, 76-84. [CrossRef]

17. Reyns, N.B.; Eggleston, D.B.; Luettich, R.A. Secondary dispersal of early juvenile blue crabs within a wind-driven estuary. Limnol. Oceanogr. 2006, 51, 1982-1995. [CrossRef]

18. Tromble, E.; Kolar, R.; Dresback, K.; Luettich, R. River Flux Boundary Conditions in a Coupled Hydrologic-Hydrodynamic Modeling System. In Proceedings of International Conference on Estuarine and Coastal Modeling 2011, St. Augustine, FL, USA, 7-9 November 2011; Spaulding, M.L., Ed.; ASCE: Reston, VA, USA, 2013; pp. 510-527.

19. Dietrich, J.C.; Trahan, C.J.; Howard, M.T.; Fleming, J.G.; Weaver, R.J.; Tanaka, S.; Yu, L.; Luettich, R.A., Jr.; Dawson, C.N.; Westerink, J.J.; et al. Surface Trajectories of Oil Transport along the Northern Coastline of the Gulf of Mexico. Cont. Shelf Res. 2012, 41, 17-47. [CrossRef]

20. Alizad, K.; Hagen, S.C.; Morris, J.T.; Bacopoulos, P.; Bilskie, M.V.; Weishampel, J.F.; Medeiros, S.C. A coupled two-dimensional hydrodynamic-marsh model with biological feedback. Ecol. Model. 2016, 327, $29-43$. [CrossRef]

21. Lyard, F.; Lefevre, F.; Letellier, T.; Francis, O. Modelling the Global Ocean Tides: Modern Insights from FES2004. Ocean Dyn. 2006, 56, 394-415. [CrossRef]

22. Westerink, J.J.; Luettich, R.A.; Scheffner, N.W. ADCIRC: An Advanced Three-Dimensional Circulation Model for Shelves, Coasts, and Estuaries, Report 3: Development of a Tidal Constituent Database for the Western North Atlantic and Gulf of Mexico; Technical Report DRP 92-6; U.S. Army Engineer Research and Development Center, Coastal and Hydraulics Laboratory: Vicksburg, MS, USA, 1993. Available online: http:/ /www.unc. edu/ims/adcirc/publications/1993/1993_Westerink02.pdf (accessed on 27 June 2016).

23. Mukai, A.Y.; Westerink, J.J.; Luettich, R.A.; Mark, D. Eastcoast 2001: A Tidal Constituent Database for the Western North Atlantic, Gulf of Mexico and Caribbean Sea; Technical Report ERDC/CHL TR-02-24; U.S. Army Engineer Research and Development Center, Coastal and Hydraulics Laboratory: Vicksburg, MS, USA, 2002; p. 201. Available online: http://www.unc.edu/ims/adcirc/publications/2002/2002_Mukai01.pdf (accessed on 27 June 2016).

24. ADCIRC Tidal Databases-ADCIRC. Available online: http://adcirc.org/products/adcirc-tidal-databases / (accessed on 1 July 2016).

25. Westerink, J.J.; Luettich, R.A.; Muccino, J.C. Modelling tides in the western North Atlantic using unstructured graded grids. Tellus A 1994, 46, 178-199. [CrossRef]

26. Blain, C.A.; Westerink, J.J.; Luettich, R.A. The influence of domain size on the response characteristics of a hurricane storm surge model. J. Geophys. Res. 1994, 99, 18467-18479. [CrossRef]

27. Bathymetric Data Viewer. Available online: http://maps.ngdc.noaa.gov/viewers/bathymetry/ (accessed on 8 September 2016).

28. Schureman, P. Manual of Harmonic Analysis and Prediction of Tides; Special Publication 98, Coast and Geodetic Survey; U.S. Department of Commerce: Washington, DC, USA, 1958; p. 317.

29. Kinnmark, I.P.E. The Shallow Water Wave Equations: Formulations, Analysis and Application; Springer: Berlin, Germany, 1986.

30. Luettich, R.A.; Westerink, J.J.; Scheffner, N.W. ADCIRC: An Advanced Three-Dimensional Circulation Model for Shelves, Coasts, and Estuaries; Report 1: Theory and Methodology of ADCIRC-2DDI and ADCIRC-3DL; Technical Report CERC-TR-DRP-92-6; U.S. Army Corps of Engineers, U.S. Department of the Army: Washington, DC, USA, 1992.

31. Kolar, R.L.; Gray, W.G.; Westerink, J.J.; Luettich, R.A. Shallow Water Modeling in Spherical Coordinates: Equation Formulation, Numerical Implementation and Application. J. Hydraul. Res. 1994, 32, 3-24. [CrossRef]

32. Bunya, S.; Dietrich, J.C.; Westerink, J.J.; Ebersole, B.A.; Smith, J.M.; Atkinson, J.H.; Jensen, R.; Resio, D.T.; Luettich, R.A.; Dawson, C.; et al. A High-Resolution Coupled Riverine Flow, Tide, Wind, Wind Wave, and Storm Surge Model for Southern Louisiana and Mississippi. Part 1: Model Development and Validation. Mon. Weather Rev. 2010, 138, 345-377. [CrossRef]

33. OSU Tidal Data Inversion. Available online: http://volkov.oce.orst.edu/tides/global.html (accessed on 27 June 2016).

34. NOAA/NOS's VDatum 3.6: Vertical Datums Transformation. Available online: http://vdatum.noaa.gov/ welcome.html (accessed on 27 June 2016). 
35. Hess, K.; Spargo, E.; Wong, A.; White, S.; Gill, S. VDatum for Central Coastal North Carolina: Tidal Datums, Marine Grids, and Sea Surface Topography; NOAA Technical Report NOS CS 21; U.S. Department of Commerce: Silver Spring, MD, USA, 2005. Available online: http://vdatum.noaa.gov/download/publications/2005_ TechReport_CS21.pdf (accessed on 16 June 2016).

36. Spargo, E.; White, S.; Hess, K. VDatum for the Northeast Gulf of Mexico from Mobile Bay, Alabama, to Cape San Blas, Florida: Tidal Datum Modeling and Population of the Marine Grids; NOAA Technical Report NOS CS 14; U.S. Department of Commerce: Silver Spring, MD, USA, 2008. Available online: http://vdatum.noaa. gov/download/publications/TM_NOS-CS14_FY08_28_EmilyHess_NEGulfOfMexico.pdf (accessed on 16 June 2016).

37. Yang, Z.; Myers, E.; Wong, A.; White, S. VDatum for Chesapeake Bay, Delaware Bay and Adjacent Coastal Water Areas: Tidal Datums and Sea Surface Topography; NOAA Technical Report NOS CS 15; U.S. Department of Commerce: Silver Spring, MD, USA, 2008. Available online: http://vdatum.noaa.gov/download/ publications/TM_NOS-CS15_FY08_26_Yang_VDatumCHES-DEL.pdf (accessed on 16 June 2016).

38. Yang, Z.; Myers, E.; White, S. VDatum for Eastern Louisiana and Mississippi Coastal Waters: Tidal Datums, Marine Grids, and Sea Surface Topography; NOAA Technical Memorandum NOS CS 19; U.S. Department of Commerce: Silver Spring, MD, USA, 2010. Available online: https://vdatum.noaa.gov/download/publications/CS_19_ FY09_26_Zizang_VDatum_NewOrleans_techMemor.pdf (accessed on 16 June 2016).

39. Yang, Z.; Myers, E.; White, S. VDatum for Great South Bay, New York Bight and New York Harbor: Tidal Datums, Marine Grids, and Sea Surface Topography; NOAA Technical Memorandum NOS CS 21; U.S. Department of Commerce: Silver Spring, MD, USA, 2010. Available online: https://vdatum.noaa.gov/download/ publications/CS_21_FY09_25_Zizang_VDatum_GreatSouthBay_techMemor.pdf (accessed on 16 June 2016).

40. Yang, Z.; Myers, E.; Jeong, I.; White, S. VDatum for Coastal Waters from the Florida Shelf to the South Atlantic Bight: Tidal Datums, Marine Grids, and Sea Surface Topography; NOAA Technical Memorandum NOS CS 27; U.S. Department of Commerce: Silver Spring, MD, USA, 2012. Available online: https:/ /vdatum.noaa.gov/ download/publications/TM_NOS-CS27_FY12-14_VDatum_FL_SA_zyang.pdf (accessed on 16 June 2016).

41. Xu, J.; Myers, E.; Jeong, I.; White, S. VDatum for Coastal Waters of Texas and Western Louisiana: Tidal Datums and Topography of the Sea Surface; NOAA Technical Memorandum NOS CS 29; U.S. Department of Commerce: Silver Spring, MD, USA, 2013. Available online: https://vdatum.noaa.gov/download/publications/TM_ NOS-CS29_FY13_Xu_TexasWesternLouisiana.pdf (accessed on 16 June 2016).

42. Yang, Z.; Myers, E.; Jeong, I.; White, S. VDatum for the Gulf of Maine: Tidal Datums and Topography of the Sea Surface; NOAA Technical Memorandum NOS CS 31; U.S. Department of Commerce: Silver Spring, MD, USA, 2013. Available online: http://vdatum.noaa.gov/download/publications/TM_NOS_CS_31_FY13_04_ Yang_VDatumGulfOfMaine.pdf (accessed on 16 June 2016).

43. Wang, J.; Myers, E.; Jeong, I.; White, S. VDatum for the Coastal Waters of Puerto Rico and the U. S. Virgin Islands: Tidal Datums, Marine Grid, and Sea Surface Topography; NOAA Technical Memorandum NOS CS 33; U.S. Department of Commerce: Silver Spring, MD, USA, 2013. Available online: https://vdatum. noaa.gov/download/publications/TM_NOS_CS33_FY14_02_JWang_VDatumPuertoRico.pdf (accessed on 16 June 2016).

44. VDatum Manual for Development and Support of NOAA's Vertical Datum Transformation Tool, VDatum. Version 1.01. 2012. Available online: http://www.nauticalcharts.noaa.gov/csdl/publications/Manual_2012. 06.26.doc (accessed on 27 June 2016).

45. Bacopoulos, P.; Parrish, D.M.; Hagen, S.C. Unstructured mesh assessment for tidal model of the South Atlantic Bight and its estuaries. J. Hydraul. Res. 2011, 49, 487-502. [CrossRef]

46. Amante, C.; Eakins, B.W. ETOPO1 1 Arc-Minute Global Relief Model: Procedures, Data Sources and Analysis; NOAA Technical Memorandum NESDIS NGDC-24; National Geophysical Data Center, NOAA: Boulder, CO, USA, 2009. Available online: https://www.ngdc.noaa.gov/mgg/global/relief/ETOPO1/docs/ETOPO1.pdf (accessed on 2 November 2012).

47. ETOPO1 Global Relief. Available online: http://www.ngdc.noaa.gov/mgg/global/global.html (accessed on 27 June 2016).

48. Becker, J.J.; Sandwell, D.T.; Smith, W.H.F.; Braud, J.; Binder, B.; Depner, J.; Fabre, D.; Factor, J.; Ingalls, S.; Kim, S.-H.; et al. Global Bathymetry and Elevation Data at 30 Arc Seconds Resolution: SRTM30_PLUS. Mar. Geod. 2009, 32, 355-371. [CrossRef] 
49. Sandwell, D.T.; Müller, R.D.; Smith, W.H.F.; Garcia, E.; Francis, R. New global marine gravity model from CryoSat-2 and Jason-1 reveals buried tectonic structure. Science 2014, 346, 65-67. [CrossRef]

50. Satellite Geodesy, IGPP, SIO, UCSD | Global Topography | SRTM30, Multibeam and Predicted. Available online: http:/ / topex.ucsd.edu/WWW_html/srtm30_plus.html (accessed on 27 June 2016).

51. Global Tide - FES: Aviso+. Available online: http://www.aviso.altimetry.fr/en/data/products/auxiliaryproducts/global-tide-fes.html (accessed on 27 June 2016).

52. Egbert, G.D.; Bennett, A.F.; Foreman, M.G.G. TOPEX/POSEIDON tides estimated using a global inverse model. J. Geophys. Res. 1994, 99, 24821-24852. [CrossRef]

53. Egbert, G.D.; Erofeeva, S.Y. Efficient inverse modeling of barotropic ocean tides. J. Atmos. Oceanic Technol. 2002, 19, 183-204. [CrossRef]

54. Carrère, L.; Lyard, F.; Cancet, M.; Roblou, L.; Guillot, A. FES2012: A new global tidal model taking advantage of nearly 20 years of altimetry measurements. In Proceedings of meeting "20 Years of Progress in Radar Altimetry Symposium", Venice, Italy, 24-29 September 2012.

55. USGS Coastal and Marine Geology—usSEABED. Available online: http://walrus.wr.usgs.gov/usseabed/ index.html (accessed on 29 June 2016).

56. Kolar, R.L.; Westerink, J.J.; Cantekin, M.E.; Blain, C.A. Aspects of nonlinear simulations using shallow-water models based on the wave continuity equation. Comput. Fluids 1993, 23, 523-538. [CrossRef]

57. NOAA Tides and Currents. Available online: http://tidesandcurrents.noaa.gov/ (accessed on 8 September 2016).

58. IHO Tidal Constituent Bank: Station Catalogue; Department of Fisheries and Oceans: Ottawa, ON, Canada, 1979.

59. Qi, S. Use of International Hydrographic Organization Tidal Data for Improved Tidal Prediction. Master's Thesis, Portland State University, Portland, OR, USA, December 2012.

60. ADCIRC Utility Programs-ADCIRC. Available online: http://adcirc.org/home/related-software/adcircutility-programs/ (accessed on July 2016).

(C) 2016 by the authors; licensee MDPI, Basel, Switzerland. This article is an open access article distributed under the terms and conditions of the Creative Commons Attribution (CC-BY) license (http://creativecommons.org/licenses/by/4.0/). 